\title{
Recovery of $\mathrm{Zn}^{2+}$ and $\mathrm{Ni}^{2+}$ Binary from Watewater using Integrated Biosorption and Electro-deposition
}

\author{
By \\ Shahrad Khodaei Booran \\ Bachelor of Engineering, Ryerson University, Toronto, Canada, 2011
}

\author{
A thesis \\ presented to Ryerson University \\ in partial fulfillment of the \\ requirements for the degree of \\ Master of Applied Science \\ in the Program of \\ Chemical Engineering
}

Toronto, Ontario, Canada, 2013

(c) Shahrad Khodaei Booran, 2013 


\section{Author Declaration}

I hereby declare that this thesis is my own work that, to the best of my knowledge and belief. I authorize Ryerson University to lend this thesis to other institutions or individuals for the purpose of scholarly research.

\section{Shahrad Khodaei Booran}

I further authorize Ryerson University to produce this thesis by photocopying or by other means, in total or in part, at the request of their institutions or individuals for the purpose of scholarly research.

\section{Shahrad Khodaei Booran}




\section{Abstract}

In 2012, the United States environmental protection agency (USEPA) prepared a list of 129 organic and inorganic pollutants found in wastewater that constitute serious health hazards. This list includes the following heavy metals: cadmium, chromium, lead, mercury, nickel and zinc. The effects of bed depths from 0.5 to $2.0 \mathrm{~m}$, liquid flow rates from 0.1 to $0.5 \mathrm{~L}^{\mathrm{min}}{ }^{-1}$, biosorbent particle sizes of 0.5 to 2 inches $(1.27-5.08 \mathrm{~cm})$ and metal concentrations from 10 to $50 \mathrm{mg}-\mathrm{Zn}-\mathrm{Ni} / \mathrm{L}$ on biosorption service were investigated. The best performance in biosorption of $\mathrm{Zn}^{2+}$ and $\mathrm{Ni}^{2+}$ binary solutions was at the smallest biosorbent particle size $(0.5 \mathrm{inch})$, highest bed depth $(2 \mathrm{~m})$, lowest flow rate $\left(0.1 \mathrm{~L} \cdot \mathrm{min}^{-1}\right)$ and smallest initial concentration $(10 \mathrm{mg} / \mathrm{L})$.

For biomass regeneration, the effects of the type of desorbing agents (hydrochloric acid, nitric acid and sulphuric acid), concentrations $(0.1$ to $0.5 \mathrm{M})$ and flow rates $(0.05$ to $0.1 \mathrm{~L} / \mathrm{min})$ on recovery of $\mathrm{Zn}^{2+}$ and $\mathrm{Ni}^{2+}$ binary mixture were investigated. The best performance in desorption of $\mathrm{Zn}^{2+}$ and $\mathrm{Ni}^{2+}$ binary solutions were $0.1 \mathrm{M} \mathrm{H}_{2} \mathrm{SO}_{4}$ and a $0.05 \mathrm{~L} / \mathrm{min}$ inlet flow rate. Moreover, the reusability of wheat straw was examined by carrying out five successive biosorption/desorption, and the results indicated that wheat straw retained its zinc and nickel adsorption capacity in all five sorption/desorption cycles.

Electro-deposition was also used to remove metal ions from concentrated $\mathrm{Zn}^{+2}$ and $\mathrm{Ni}^{+2}$ binary solutions (about $340 \mathrm{ppm}$ ) from the desorption step. It was found that the electrodeposition could reduce the metal concentrations down to wastewater discharge limit of $2 \mathrm{mg}-\mathrm{Zn}$ $\mathrm{Ni} / \mathrm{L}$.

Lastly, economical evaluation showed that the recovery of the heavy metals using Integrated Biosorption and Electro-deposition has great advantages from both technical and economical perspectives over the chemical precipitation technology. 


\section{Acknowledgement}

I wish to express my sincere gratitude to Dr. Huu Doan, for his kind guidance, supervision and suggestions throughout the entire period of this study.

I would like to thank my co-supervisor, Dr. Ali Lohi, for giving variable comments and suggestions my research.

I am very grateful for the invaluable assistance of faculty members and technologists in Chemical Engineering Department of Ryerson University, especially those provided by Ali Hematti, Daniel Boothe and Tondar Tajrobehkar during the equipment manufacture and system setup.

I would like to thanks Alison MacLeod, Isabella Fernandes and Louise Lichacz in the Depart of Chemical Engineering.

I would also like to thank my family and friends for their supports and encouragements. 


\section{Table of content}

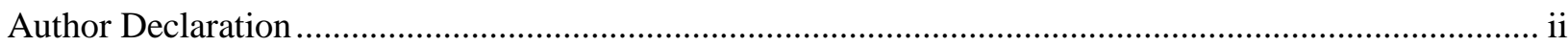

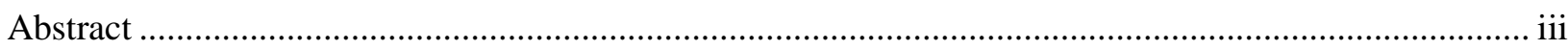

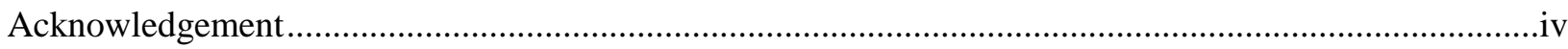

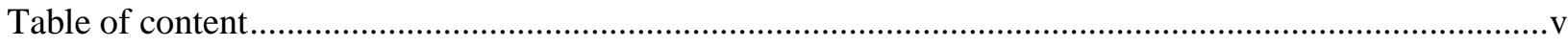

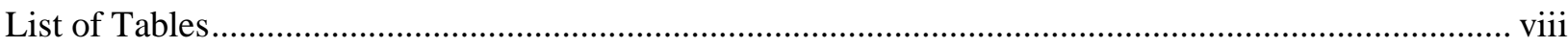

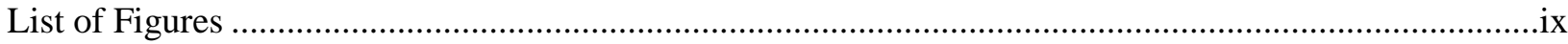

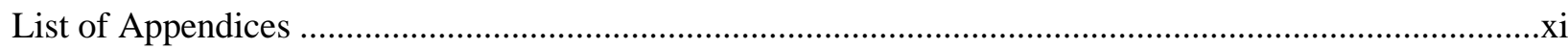

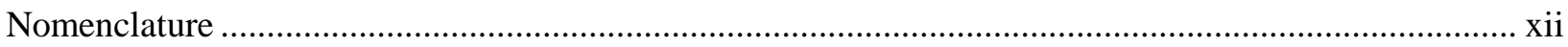

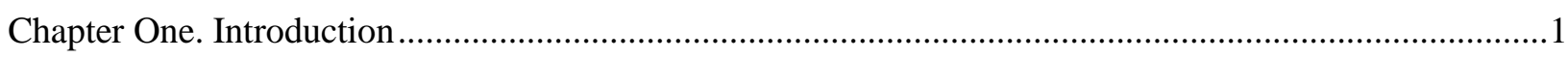

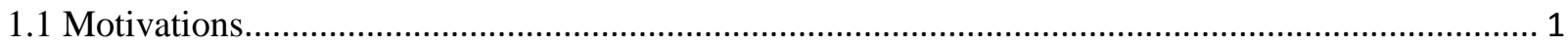

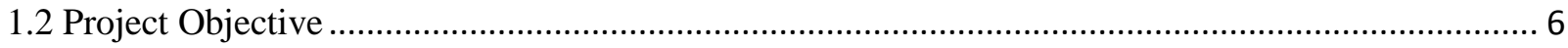

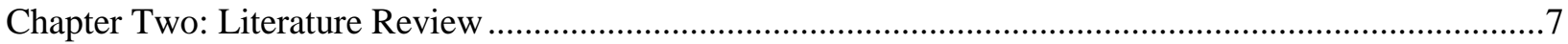

2.1 Removal of metal ions technologies................................................................................... 7

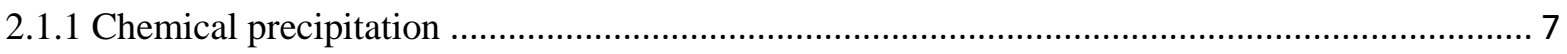

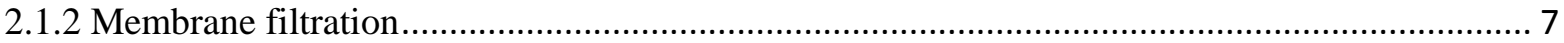

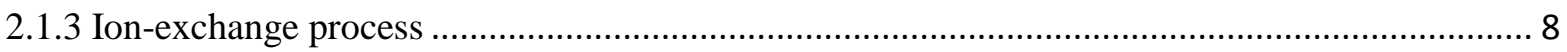

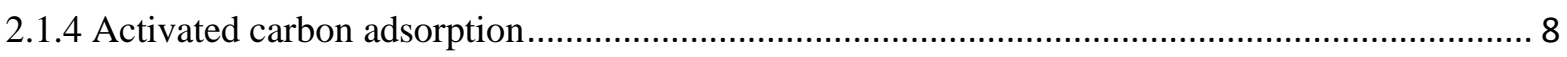

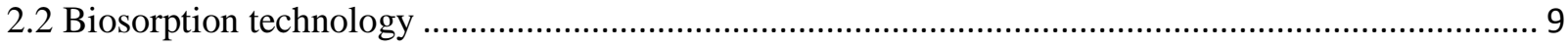

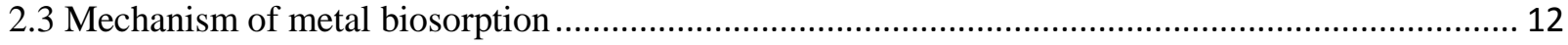

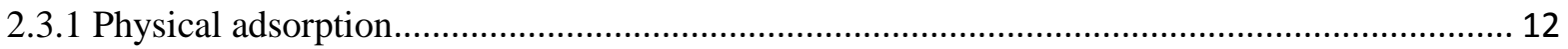

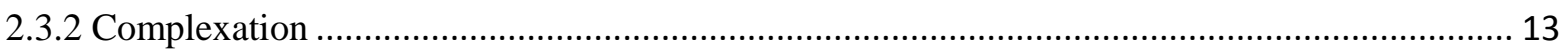

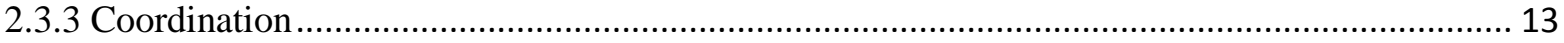

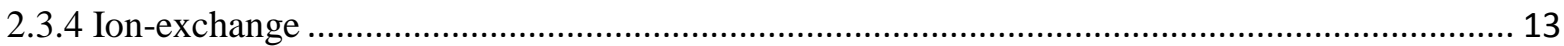

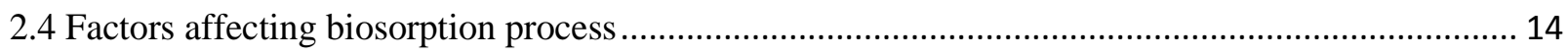

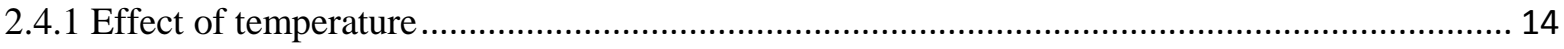

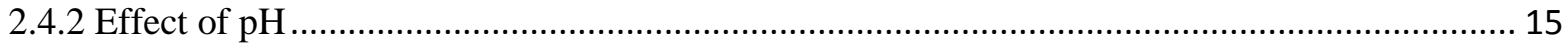

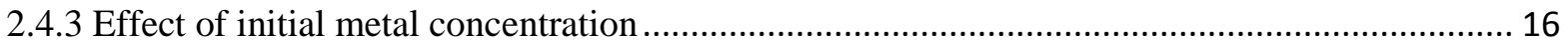

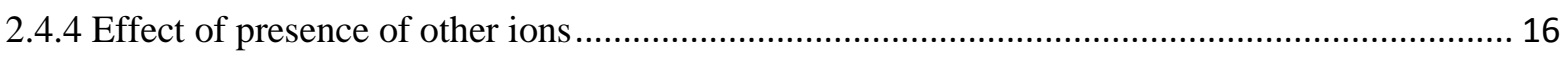

2.5 Wastewater treatment using a fixed-bed column reactor ......................................................... 17 


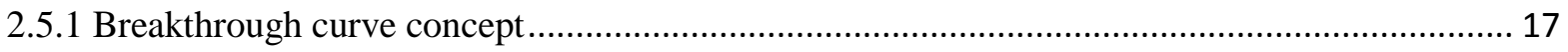

2.6 Factors affecting biosorption in a fixed-bed............................................................................. 19

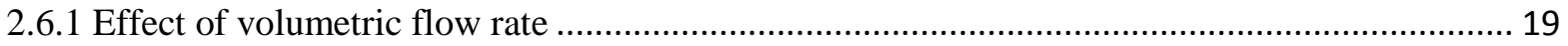

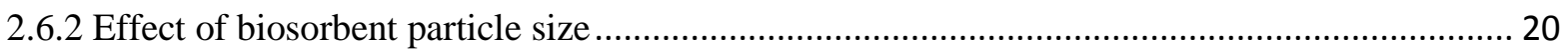

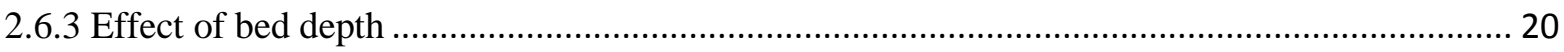

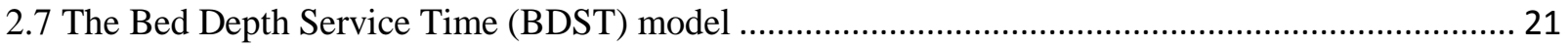

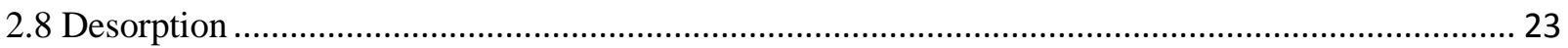

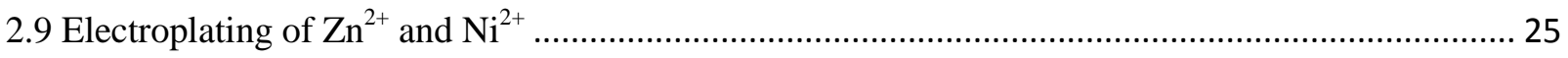

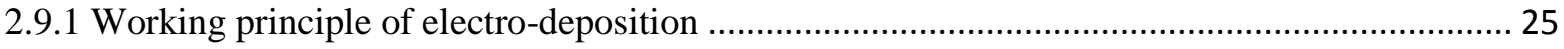

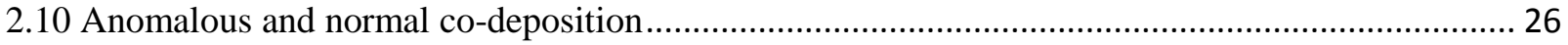

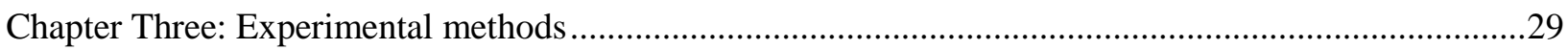

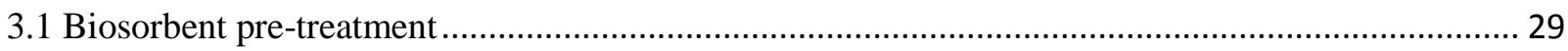

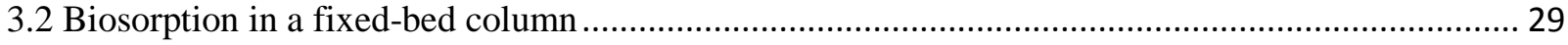

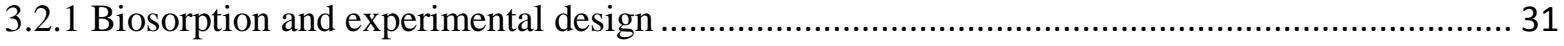

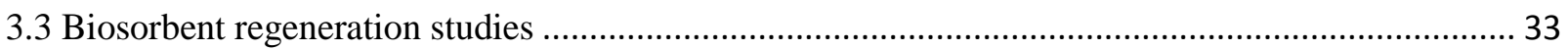

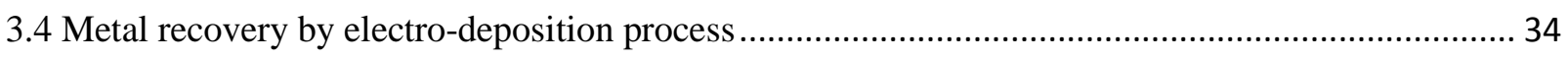

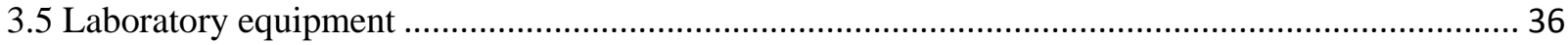

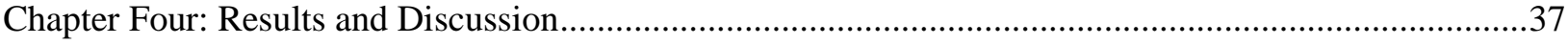

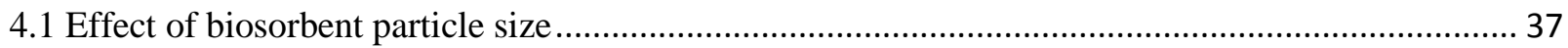

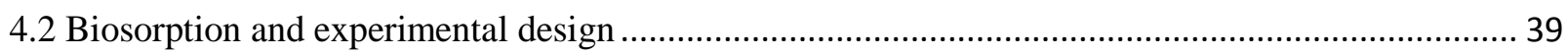

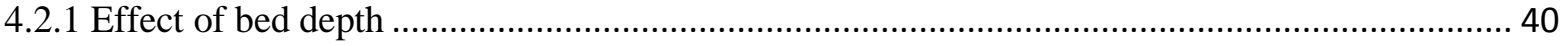

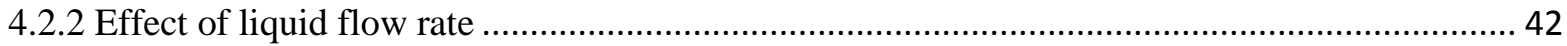

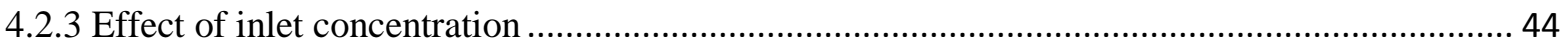

4.3 Best conditions of $\mathrm{Zn}^{2+}$ and $\mathrm{Ni}^{2+}$ binary biosorption system ................................................. 46

4.4 Bed Depth Service Time (BDST) model.................................................................................. 47

4.5 Competitive biosorption of $\mathrm{Zn}^{2+}$ and $\mathrm{Ni}^{2+}$ onto wheat straw ....................................................... 49

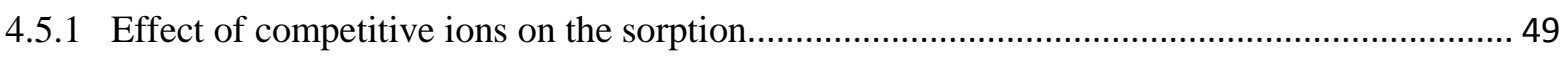

4.5.2 Biosorption of single component heavy metal solution ….................................................. 53

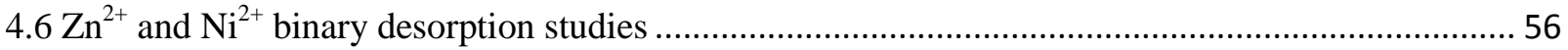

4.6.1 Effect of the type of desorbing agent and concentration ...................................................... 56

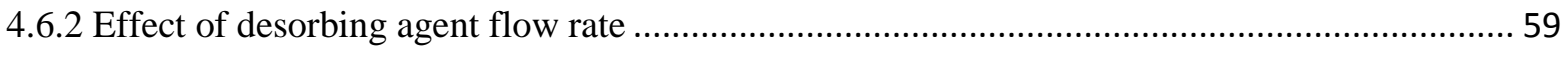

4.7 Successive removal and recovery of zinc and nickel binary solutions.......................................... 61 
4.8 Recovery of desorbed zinc and nickel: electro-deposition ....................................................... 65

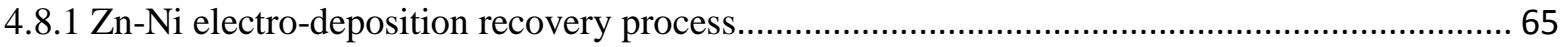

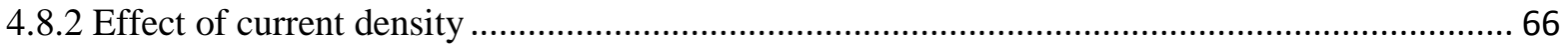

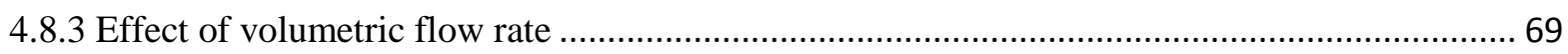

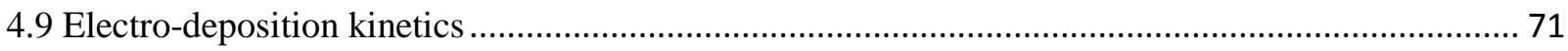

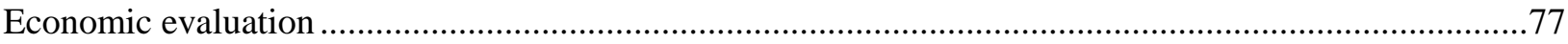

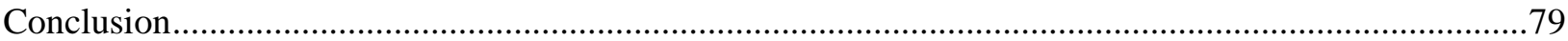

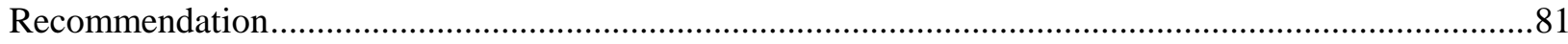

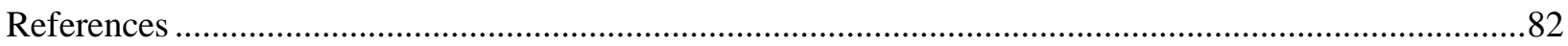

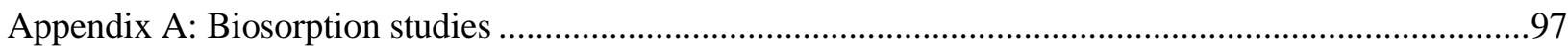

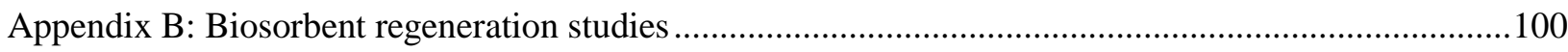

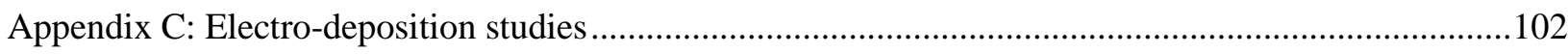

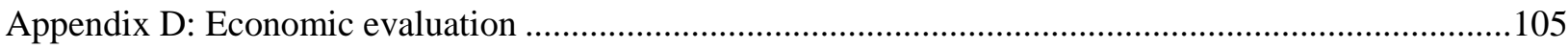




\section{List of Tables}

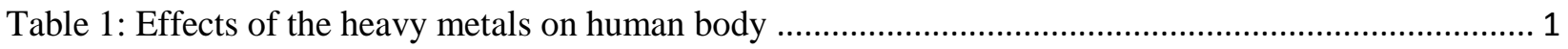

Table 2: Effluent discharge limits for the city of Toronto..................................................................... 2

Table 3: Advantages and disadvantages of conventional physico-chemical methods for heavy metal

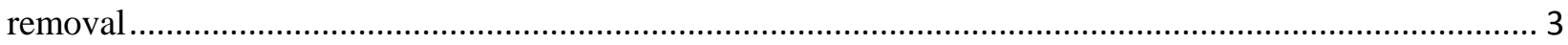

Table 4: Bacterial biosorbent used for metal removal...................................................................... 10

Table 5: Yeast (in various forms) biosorbent used for metal removal ...................................................... 10

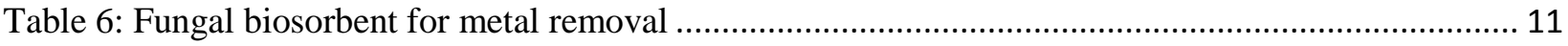

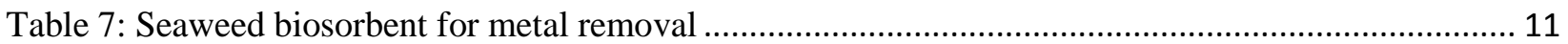

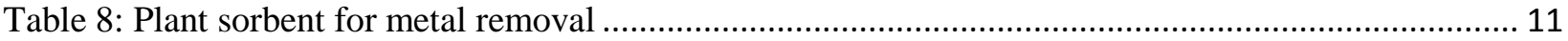

Table 9: Experimental factors and levels for the RSM model ............................................................. 33

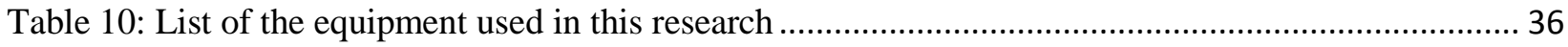

Table 11: CCF experimental design for adsorption of $\mathrm{Zn}^{2+}$ and $\mathrm{Ni}^{2+}$ binary ions.................................... 39

Table 12: $\mathrm{Zn}^{2+}$ and $\mathrm{Ni}^{2+}$ biosorption performances at varied bed depths .............................................. 42

Table 13: $\mathrm{Zn}^{2+}$ and $\mathrm{Ni}^{2+}$ biosorption performances at varied inlet flow rate ............................................ 44

Table 14: $\mathrm{Zn}^{2+}$ and $\mathrm{Ni}^{2+}$ biosorption performances at varied initial concentration ................................... 46

Table 15: The BDST model parameters obtained from fitting of breakthrough data to the model at fixed

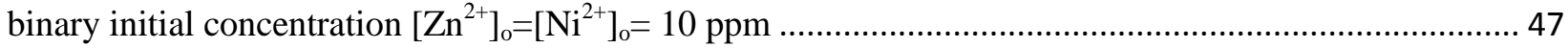

Table 16: Comparison uptake capacity, percentage removal and service time of $\mathrm{Zn}^{2+}$ and $\mathrm{Ni}^{2+}$ ions in

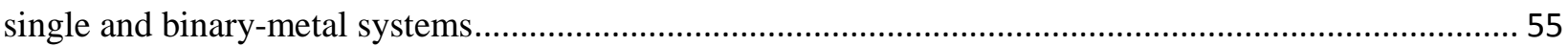

Table 17: Elution efficiency of zinc and nickel solution after three biosorption/desorption cycles using

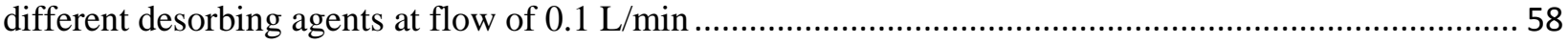

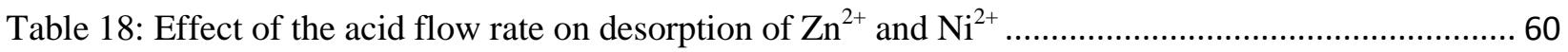

Table 19: Sorption and elution process parameters for five sorption-desorption cycles ...........................62 62

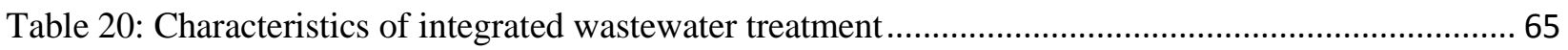

Table 21: Removal of $\mathrm{Zn}^{2+}$ at 12 hours of electro-deposition at a flow rate of $9.88{\mathrm{~L} . \mathrm{min}^{-1}}^{-\ldots . . . . . . . . . . . . . . . . . . ~} 67$

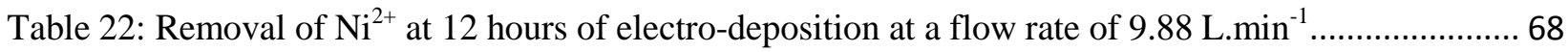

Table 23: Apparent first order rate constants for zinc ion reduction and average mass transfer coefficients during 72 hours of treatment

Table 24: Apparent first order rate constants for Nickel ion reduction and average mass transfer

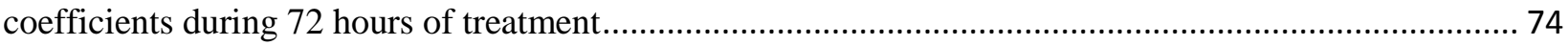

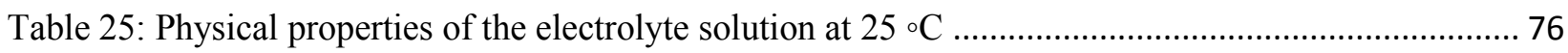




\section{List of Figures}

Figure 1: A typical breakthrough curve showing the movement of the adsorption zone, breakthrough and saturation time

Figure 2: Biosorption experimental setup: 1) pump, 2) valve, 3) flow meter, 4) adsorption columns, 5) metal ion solution feed tank, 6) desorbing agent feed tank, 7) by-pass valve for desorption process ........ 31 Figure 3: Experiment set up for electro-deposition: (1) pump, (2) by-pass or recycle valve, (3) main stream valve, (4) liquid distributor, (5) water bath, (6) electro-cell, (7) electrode spacer, (8) feed tank

Figure 4: Effect of particle size on biosorption of binary solution $\left(\mathrm{Zn}^{2+}\right.$ and $\left.\mathrm{Ni}^{2+}\right)$ in fixed-bed at bed depth $=2 \mathrm{~m}$; volumetric flow rate $=0.5 \mathrm{~L} / \mathrm{min}$; initial concentration $\left[\mathrm{Zn}^{2+}\right]_{0}=\left[\mathrm{Ni}^{2+}\right]_{0}=50 \mathrm{ppm}(60$ minutes operation time)

Figure 5: Effect of bed depth on adsorption of $\mathrm{Zn}^{2+}$ in binary solution at volumetric flow rate $=0.3 \mathrm{~L} / \mathrm{min}$; initial concentration $\left[\mathrm{Zn}^{2+}\right]_{0}=\left[\mathrm{Ni}^{2+}{ }_{0}=30 \mathrm{ppm}\right.$

Figure 6: Effect of bed depth on adsorption of $\mathrm{Ni}^{2+}$ in binary solution at volumetric flow rate $=0.3 \mathrm{~L} / \mathrm{min}$; initial concentration $\left[\mathrm{Zn}^{2+}\right]_{0}=\left[\mathrm{Ni}^{2+}\right]_{0}=30 \mathrm{ppm}$.

Figure 7: Effect of liquid flow rate on adsorption of $\mathrm{Zn}^{2+}$ in binary solution at bed depth $=1.25 \mathrm{~L} / \mathrm{min}$; initial concentration $\left[\mathrm{Zn}^{2+}\right]_{0}=\left[\mathrm{Ni}^{2+}\right]_{0}=30 \mathrm{ppm}$.

Figure 8: Effect of liquid flow rate on adsorption of $\mathrm{Ni}^{2+}$ in binary solution at bed depth $=1.25 \mathrm{~L} / \mathrm{min}$; initial concentration $\left[\mathrm{Zn}^{2+}\right]_{0}=\left[\mathrm{Ni}^{2+}\right]_{0}=30 \mathrm{ppm}$.

Figure 9: Effect of the inlet concentration on adsorption of $\mathrm{Zn}^{2+}$ in binary solution at bed depth $=1.25$

$\mathrm{L} / \mathrm{min}$; volumetric flow rate $=0.3 \mathrm{~L} / \mathrm{min}$

Figure 10: Effect of the inlet concentration on adsorption of $\mathrm{Ni}^{2+}$ in binary solution at bed depth $=1.25$

$\mathrm{L} / \mathrm{min}$; volumetric flow rate $=0.3 \mathrm{~L} / \mathrm{min}$

Figure 11: BDST model for (A) $\mathrm{Zn}^{2+}$ and (B) $\mathrm{Ni}^{2+}$ at different flow rates for at given binary initial concentration $\left[\mathrm{Zn}^{2+}\right]_{0}=\left[\mathrm{Ni}^{2+}\right]_{0}=10 \mathrm{ppm}$.

Figure 12: Comparison of metal uptakes of $\mathrm{Zn}^{2+}$ and $\mathrm{Ni}^{2+}$ in binary-metal systems at different $\mathrm{Co}[\mathrm{Zn}]$ for a given $\mathrm{Co}[\mathrm{Ni}]=10 \mathrm{mg} / \mathrm{L}$; volumetric flow rate of $0.1 \mathrm{~L} / \mathrm{min}$; and bed depths of 2 and $0.5 \mathrm{~m}$. 52

Figure 13: Comparison of metal uptakes of $\mathrm{Zn}^{2+}$ and $\mathrm{Ni}^{2+}$ in binary-metal systems at different $\mathrm{Co}[\mathrm{Zn}]$ for a given $\mathrm{Co}[\mathrm{Ni}]=100 \mathrm{mg} / \mathrm{L}$; volumetric flow rate of $0.1 \mathrm{~L} / \mathrm{min}$ and bed depth of $0.5 \mathrm{~m}$.

Figure 14: Comparison breakthrough curves of biosorption of $\mathrm{Zn}^{2+}$ in single-metals and binary solutions53 Figure 15: Comparison breakthrough curves of biosorption of $\mathrm{Ni}^{2+}$ in single-metals and binary solutions 54 Figure 16: Effect of sulfuric acid concentration on desorption of $\mathrm{Zn}^{2+}$ at flow rate of $0.1 \mathrm{~L} / \mathrm{min}$............ 58 Figure 17: Effect of sulfuric acid concentration on desorption of $\mathrm{Ni}^{2+}$ at flow rate of $0.1 \mathrm{~L} / \mathrm{min}$.............. 59 Figure 18: Effect of flow rate on desorption of $\mathrm{Zn}^{2+}$ at $0.1 \mathrm{M}\left(\mathrm{H}_{2} \mathrm{SO}_{4}\right)$ acid concentration......................... 60 Figure 19: Effect of flow rate on desorption of $\mathrm{Ni}^{2+}$ at $0.1 \mathrm{M}\left(\mathrm{H}_{2} \mathrm{SO}_{4}\right)$ acid concentration ........................ 61 Figure 20: Breakthrough curves for A) zinc and B) nickel by wheat straw for five biosorption/desorption cycles (bed depth $=2 \mathrm{~m}$; volumetric flow rate $=0.1 \mathrm{~L} / \mathrm{min} ;\left[\mathrm{Zn}^{2+}\right]_{0}=\left[\mathrm{Ni}^{2+}\right]_{0}=10 \mathrm{ppm}$ ) 63 Figure 21: Elution curves for A) zinc and B) nickel by Wheat straw for five biosorption/desorption cycles

Figure 22: Effect of current density on (A) $\mathrm{Zn}^{2+}$ and (B) $\mathrm{Ni}^{2+}$ electro-deposition at 9.88 L.min ${ }^{-1}$...... 68

Figure 23: Effect of flow rate on the removal of $\mathrm{Zn}^{2+}$ and $\mathrm{Ni}^{2+}$ at given current density of $3.75 \mathrm{~mA} . \mathrm{cm}^{-2}$ (24 hour) 70

Figure 24: Effect of volumetric flow rate on A) $\mathrm{Zn}^{2+}$ and B) $\mathrm{Ni}^{2+}$ reduction during 72 hours of treatment 71 
Figure 25: $\mathrm{Ln}(\mathrm{C} / \mathrm{Co})$ versus time for $\mathrm{Zn}^{2+}$ depositions at different flow rates .......................................... 73

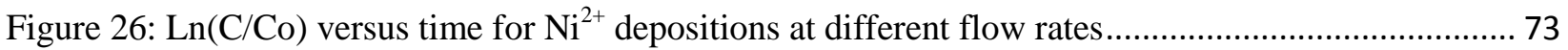

Figure 27: $\mathrm{J}_{\mathrm{D}}$ factor at various Reynolds number for the transfer of $\mathrm{Zn}^{2+}$ and $\mathrm{Ni}^{2+}$ binary in the electro-cell 


\section{List of Appendices}

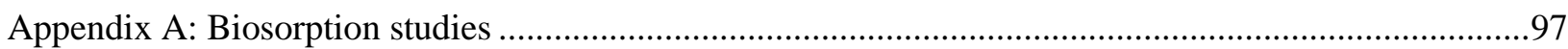

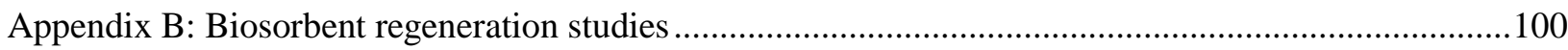

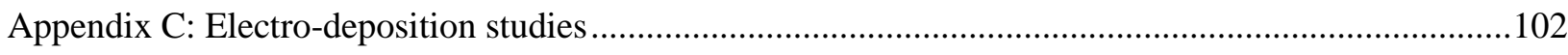

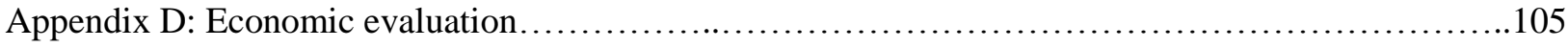




\section{Nomenclature}

\section{Symbol}

A

BDST

$\mathrm{C}$

$\mathrm{C}_{\mathrm{o}}$

$\mathrm{C}_{\mathrm{b}}$

$\mathrm{CCF}$

$\mathrm{D}_{\mathrm{i}}$

F

I

i

$\mathrm{J}_{\mathrm{D}}$

$\mathrm{k}$

$\mathrm{k}_{\mathrm{c}}$

LPM

L

M

MTZ

$\mathrm{m}$

$\mathrm{N}_{\mathrm{o}}$

$\mathrm{N}$

n

ppm

$\mathrm{q}_{\mathrm{T}}$

$\mathrm{R}$

$\mathrm{Re}$

RSM

$\mathrm{Sh}$

$\mathrm{Sc}$

$\mathrm{SS}_{\mathrm{E}}$

$\mathrm{SS}_{\mathrm{PE}}$

$\mathrm{SS}_{\mathrm{LOF}}$

$t_{b}$

$\mathrm{t}_{\mathrm{s}}$

$\mathrm{T}$

V

\section{Description}

Surface area, $\mathrm{m}^{2}$

Bed Depth Service Time

Effluent solution concentration, mg/L

Initial concentration of solute, $\mathrm{mg} / \mathrm{L}$

Breakthrough point concentration, $\mathrm{mg} / \mathrm{L}$

Central Composite Face-centered

Diffusion coefficient of a component $\mathrm{i}, \mathrm{m}^{2} / \mathrm{s}$

The Faraday constant $(96,485)$, A.s/mol

Electrical current, $\mathrm{mA}$

Current density, $\mathrm{mA} / \mathrm{cm}^{2}$

Dimensionless factor for mass transfer

Adsorption rate constant, L/mg.min

Average mass transfer coefficient, $\mathrm{m} / \mathrm{s}$

Liter/min

Characteristic length, $\mathrm{m}$

Mass of adsorbent, $g$

Mass transfer zone

Number of moles of electro-active species, mol

Adsorption capacity, mg/L

Molar flux, $\mathrm{mol} / \mathrm{m}^{2}$.s

Number of electrons

part per million

Equilibrium uptake per $\mathrm{g}$ of the adsorbent, $\mathrm{mg} / \mathrm{g}$

Universal gas constant (8.314), J/mol.K

Reynolds number

Response Surface Methodology

Sherwood number

Schmidt number

Squares of the residuals or error

Total sum of square deviations

Sum of square due to lack of fit

Service time, $\min$

Saturation time or equilibrium time, min

Absolute solution temperature, Kelvin

Throughout volume, L 


$\begin{array}{ll}\mathrm{Z} & \text { Electrical charge number } \\ \mathrm{Z} & \text { Bed depth of column, } \mathrm{m}\end{array}$

\section{Greek Symbols Description}

$\begin{array}{ll}\beta & \text { Coefficient } \\ \mu & \text { Viscosity, g/m.s } \\ \rho & \text { Density, } \mathrm{kg} / \mathrm{m}^{3} \\ \nu & \text { Superficial velocity of liquid, } \mathrm{m} / \mathrm{min} \\ \sigma & \text { Standard deviation } \\ \Delta \mathrm{G}^{\mathrm{o}} & \text { Gibb's free energy change, } \mathrm{J} / \mathrm{mol} \\ \Delta \mathrm{H}^{\mathrm{o}} & \text { Enthalpy change, } \mathrm{J} / \mathrm{mol} \\ \Delta \mathrm{S}^{\mathrm{o}} & \text { Entropy change, } \mathrm{J} / \mathrm{mol} . \mathrm{K}\end{array}$




\section{Chapter One. Introduction}

\subsection{Motivations}

Excessive heavy metals released through industrial sectors, such as: fertilizer production, metal finishing industry, mining and metal plating industry have led to a dangerous increase of heavy metals in the environment (Duruibe et al., 2007). Table 1 shows some of the negative impact of lead, mercury, cadmium, chromium (VI), zinc and nickel have on human body (U.S.

Environmental Protection Agency (EPA), 2012).

Table 1: Effects of the heavy metals on human body

\begin{tabular}{|c|c|c|}
\hline Heavy metals & Toxic Effects & References \\
\hline Lead & $\begin{array}{l}\text { - Kidney damage } \\
\text { - Disruption of nervous systems } \\
\text { - Brain damage } \\
\text { - Diminished learning abilities of } \\
\text { children }\end{array}$ & $\begin{array}{l}\text { Water Treatment Solutions } \\
\text { Lenntech, 2011a }\end{array}$ \\
\hline Mercury & $\begin{array}{l}\text { - Disruption of the nervous system } \\
\text { - Damage to brain functions } \\
\text { - DNA damage and chromosomal } \\
\text { damage } \\
\text { - Reproductive failure }\end{array}$ & $\begin{array}{l}\text { Water Treatment Solutions } \\
\text { Lenntech, } 2011 \mathrm{~b}\end{array}$ \\
\hline Cadmium & $\begin{array}{l}\text { - Bone fracture } \\
\text { - Reproductive failure and possibly } \\
\text { even infertility } \\
\text { - Damage to the central nervous } \\
\text { system } \\
\text { - Damage to the immune system }\end{array}$ & $\begin{array}{l}\text { Water Treatment Solutions } \\
\text { Lenntech, 2011c }\end{array}$ \\
\hline Chromium (IV) & $\begin{array}{l}\text {-Respiratory problems } \\
\text { - Weakened immune systems } \\
\text { - Kidney and liver damage }\end{array}$ & $\begin{array}{l}\text { Water Treatment Solutions } \\
\text { Lenntech, 2011d }\end{array}$ \\
\hline Zinc & $\begin{array}{l}\text {-Stomach cramps } \\
\text {-Skin irritations } \\
\text {-Nausea and anaemia } \\
\text {-Damaging the pancreas and disturb } \\
\text { the protein metabolism. }\end{array}$ & $\begin{array}{l}\text { Water Treatment Solutions } \\
\text { Lenntech, 2011e }\end{array}$ \\
\hline Nickel & $\begin{array}{l}\text { - Lung embolism } \\
\text { - Respiratory failure } \\
\text { - Birth defects } \\
\text { - Heart disorders }\end{array}$ & $\begin{array}{l}\text { Water Treatment Solutions } \\
\text { Lenntech, 2011f }\end{array}$ \\
\hline
\end{tabular}


In Canada, automotive, electronics, metal finishing, mining and oil sands industries form a large economic sector. These industries generate a large quantity of wastewater containing heavy metals such as $\mathrm{Zn}^{+2}$ and $\mathrm{Ni}^{+2}$ and others (Doan et al., 2008). Typically, the wastewater from the metal finishing industry (e-coating process) contains $20 \mathrm{ppm}$ each of $\mathrm{Zn}^{+2}$ and $\mathrm{Ni}^{+2}$. However, under the government regulation with regard to wastewater containing heavy metals, the maximum allowable discharge concentration of $\mathrm{Zn}^{+2}$ and $\mathrm{Ni}^{+2}$ in Toronto is 2 ppm (Table 2) (Toronto's Sewers Bylaw, 2010). Therefore, the wastewater needs to be treated before being discharged to the environment.

Table 2: Effluent discharge limits for the city of Toronto (Toronto's Sewers Bylaw, 2010)

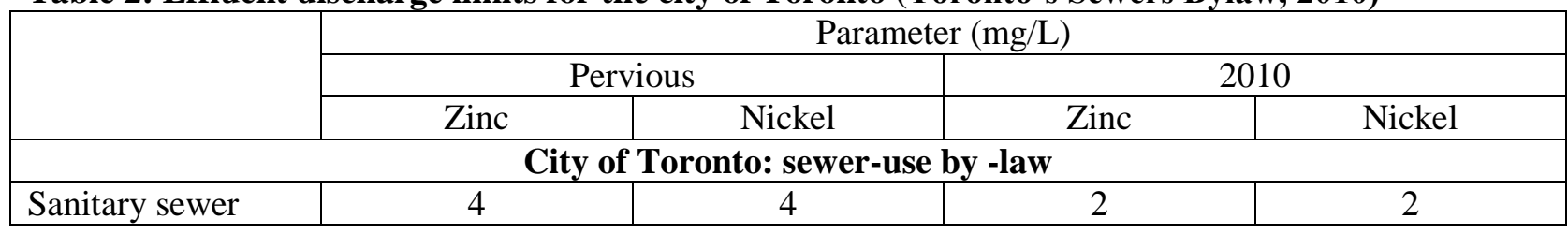

There are numerous methods to remove heavy metals from wastewater, such as: chemical precipitation, ion-exchange, adsorption by activated carbon and membrane filtration. However, most of these methods are either highly expensive or inefficient in removing heavy metals at low concentrations (Volesky, 2003; Farooq et al., 2010). Currently, chemical precipitation is widely used for the removal of metals from industrial wastewater. The major drawback of this method is the hazardous sludge generation that requires further treatment and disposal, which adds to the overall cost of the wastewater treatment (Park et al., 2010). The advantages and disadvantages of the traditional physico-chemical methods for removal of heavy metals from wastewater are listed in Table 3. 
Table 3: Advantages and disadvantages of conventional physico-chemical methods for heavy metal removal

\begin{tabular}{|c|c|c|c|}
\hline Technology & Advantages & Disadvantages & References \\
\hline Chemical precipitation & $\begin{array}{l}\text { - A well-established } \\
\text { technology } \\
\text { - High tolerance to } \\
\text { suspended solids } \\
\text { and organics }\end{array}$ & $\begin{array}{ll}- & \text { Sludge production } \\
\text { - } & \text { High capital cost } \\
& \text { (sludge handling) } \\
\text { - } & \text { Low metal selectivity }\end{array}$ & $\begin{array}{l}\text { Eccles, 1995; } \\
\text { Ahluwalia and } \\
\text { Goyal, } 2007\end{array}$ \\
\hline Ion exchange & 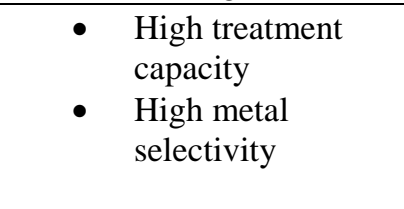 & $\begin{array}{ll}\text { - } & \text { High capital and } \\
\text { operation cost } \\
\text { - } & \text { Low tolerance to } \\
\text { organics and } \\
\text { suspended solids }\end{array}$ & $\begin{array}{l}\text { Eccles, 1995; } \\
\text { Han and Yun, 2007; } \\
\text { Ahluwalia and } \\
\text { Goyal, } 2007\end{array}$ \\
\hline $\begin{array}{l}\text { Activated carbon } \\
\text { adsorption }\end{array}$ & $\begin{array}{ll}- & \text { High heavy metal } \\
\text { removal } \\
\text { - } \\
\text { High metal } \\
\text { selectivity }\end{array}$ & $\begin{array}{ll}- & \text { High operation cost } \\
\text { - } & \text { Hard to regenerate } \\
\text { - } & \text { Low tolerance to } \\
\text { suspended solids and } \\
\text { organics }\end{array}$ & $\begin{array}{l}\text { Eccles, 1995; } \\
\text { Han and Yun, } 2007\end{array}$ \\
\hline Membrane filtration & $\begin{array}{ll}\text { - } & \text { Small footprints } \\
\text { - } & \text { High effluent } \\
\text { quality } \\
\text { - } \\
\text { Good disinfection } \\
\text { capability } \\
\text { - } \quad \begin{array}{l}\text { Low or no sludge } \\
\text { production }\end{array} \\
\end{array}$ & $\begin{array}{l}\text { - High capital cost and } \\
\text { operation cost } \\
\text { - } \quad \text { Membrane fouling }\end{array}$ & $\begin{array}{l}\text { Van Reis and } \\
\text { Zydney, 2007; Mack } \\
\text { et al., } 2004\end{array}$ \\
\hline
\end{tabular}

As the result, researchers are looking for an alternative technology for the removal of heavy metals. One of the alternative technologies has been proposed is the use of a biological material. This technique is called biosorption (Veglio and Beolchini, 1997). The main advantages of biosorption over other treatment methods are: 1) low operation cost, 2) low or no biological sludge production and 3) potential for regeneration of the biosorbent (Volesky, 2003).

A wide variety of biosorbent materials have been used to adsorb heavy metals in wastewater. These include bacterial (Tunali et al., 2006; Ziagova et al., 2007), fungal (Skowronski et al., 2001; Say et al., 2003), and agricultural by-products (Ho, 2003; Saeed et al., 2005a). However, different methods and aqueous solutions were used in various studies reported in the literature. Therefore, it is rather difficult to conclude one type of biosorbent as the most suitable material in biosorption process. In this study, wheat straw was selected as biosorbent to remove $\mathrm{Zn}^{2+}$ and 
$\mathrm{Ni}^{2+}$ binary from wastewater. Wheat straw is abundant and inexpensive in Canada (Farooq et al., 2010), and it also has a good potential for treatment of wastewater containing heavy metal ions (Lawther et al., 1995; Doan et al., 2008).

In practical operation of a full-scale biosorption process, continuous-flow columns are often preferred than batch processes (Da Costa et al., 1996; Saha et al., 2012). A Fixed-bed column provides several advantages, including: 1) high process efficiency, 2) virtually unlimited scaleup, 3) no liquid/solid separation and 4) in-situ regeneration and washing (Belter et al., 1988; Volesky, 2003). Therefore, a fixed-bed column system was used in this present study.

Furthermore, desorption of the bound metal ions from the biosorbents should be investigated. Grimm et al. (2008) and Hammaini et al. (2007) indicated that the importance of the desorption process is its recovery of bound metals ions from biomass and the regeneration of biomass. These are directly related to both reducing and saving the cost of industrial processes. Accordingly, the three common desorbing agents (hydrochloric acid, sulphuric acid and nitric acid) were examined to determine their suitability in the desorption process (Stirk and Staden, 2002; KuczajowskaZadrożna et al., 2004). Additionally, the impact of desorbing agent concentrations and flow rates on desorption performance were also investigated.

Most researchers are devoting to increase desorption efficiency and the reusability of biosorbents in their investigations (Bakkaloglu et al., 1998; Stirk and Staden, 2002; Fagundes-Klen et al., 2010). However, little experimental work focuses on the reuse and/or handing of desorbed metals in industrial production processes. This should gain a considerable attention, primarily, the effluent wastewater from desorption process typically contained high concentration of heavy 
metals which requires further treatment before being discharged to the environment. Furthermore, the reuse of valuable metals from desorption eluent can reduce the resource wastage, the material cost and also the cost of disposing hazardous metal-laden waste products. Some of the advantages of electro-deposition are: 1) low or no sludge production, 2) low maintenance cost due to a simple mechanical process (Lovley, 2000). Hence, electro-deposition process was used for recovering the heavy metals from desorption step. 


\subsection{Project Objective}

To develop an effective biosorption process for removal and recovery of heavy metal ions from wastewater, using wheat straw as biosorbent.

\section{In order to achieve the set objective, following tasks were carried out:}

i. To investigate the influence of the following parameters on biosorption performance of wheat straw:
a. Column bed depth
b. Wastewater flow rate
c. Influent metal concentration
d. Biosorbent particle size

ii. To determine best experimental conditions of a fixed bed column to maximize the biosorption service time for $\mathrm{Zn}^{2+}$ and $\mathrm{Ni}^{2+}$ binary solutions.

iii. To evaluate the applicability of the Bed Depth Service Time (BDST) model that is commonly used in simulating fixed-bed biosorption process and predicting the treatment performance.

iv. To examine $\mathrm{Zn}^{2+}$ and $\mathrm{Ni}^{2+}$ binary desorption process in the column reactor (column regeneration) and evaluate the reusability of the biosorbent for sequential $\mathrm{Zn}^{2+}$ and $\mathrm{Ni}^{2+}$ removal and recovery cycles.

v. To evaluate the performance of the electro-deposition technique for the recovery of metal ions from the concentrated $\mathrm{Zn}^{+2}$ and $\mathrm{Ni}^{+2}$ binary solutions from the desorption step. 


\section{Chapter Two: Literature Review}

\subsection{Removal of metal ions technologies}

Several methods are currently being used for the removal of heavy metals from wastewater. These technologies can be summarized as chemical precipitation, membrane filtration, ionexchange and activated carbon adsorption.

\subsubsection{Chemical precipitation}

Chemical precipitation has been the most common method to remove heavy metals and other inorganic substances from wastewater. Basically, a chelating agent, such as lime is added to the wastewater, which causes the contaminants dissolved or suspended in wastewater to forms an insoluble compound and precipitate (EPA, 2002). However, this method generates a large amount of toxic sludge that requires further treatment and disposal, which adds to the overall cost of the wastewater treatment (Park et al., 2010).

\subsubsection{Membrane filtration}

Membrane filtrations have gained quite attention for the treatment of heavy metals in wastewater (Bodnar et al., 2008). Among different membrane filtration (i.e. Ultra-filtration (UF), Nanofiltration (NF) and Reverse Osmosis (RO)), RO is most commonly applied to heavy metal removal from wastewater (Srisuwan and Thongchai, 2004; Sang et al., 2008). Reverse osmosis is a pressure-driven membrane process, where the solvent is forced to pass through the membrane by applying a hydrostatic pressure greater than the osmotic pressure of the feeding solution, while the heavy metal is retained (Crittenden et al., 2005). Some of the advantages of membrane filtration include: 1) small footprints, 2) high rejection rate and 3) no sludge production (Judd, 2006). On the other hand, one of the major drawbacks in membrane filtration is fouling. 
Membrane fouling would decrease the effluent quality, and the membrane would need to be replaced. Additionally, membrane filtration consumes a high amount of energy that increases the operational cost (Baker, 2004).

\subsubsection{Ion-exchange process}

In this process, a reversible interchange of ions between the solid and liquid phases occurs. The metal ions are removed by exchanging them with the ions held on an insoluble substance (resin) without any structural change of the resin (Dabrowski et al., 2004). Among different materials that have been used as ion exchange resin, synthetic resins are commonly preferred (Rengaraj et al., 2003). Typically, this process can effectively remove heavy metals in the range of 10 to 100

mg.L $\mathrm{L}^{-1}$, or even higher, and does not generate sludge (Bai and Bartkiewicz, 2009). Despite these advantages, ion exchange capital and operational costs are quite high (Dabrowski et al., 2004).

\subsubsection{Activated carbon adsorption}

Adsorption is a process in which contaminate (i.e. metal ions) is removed from a liquid phase by accumulation at the interface between the liquid phase and the solid phase by physical-chemical interaction (Uzun and Güze, 2000). Among different adsorbents, activated carbon is most commonly used for adsorption of heavy metals in an aqueous solution (Cheremisinoff and Cheremisinoff, 1993; Uzun and Güze, 2000). This is mainly due to its large surface area availability (Cheremisinoff and Cheremisinoff, 1993). However, the high cost for production and regeneration of the carbon is a drawback. 


\subsection{Biosorption technology}

In the last three decades due to increasing in environmental awareness and concerns, high number of research was conducted on using living or non-living microorganisms as adsorbents for the removal of low concentration metal-bearing wastewater (Modak and Natarajan, 1995). Compared with conventional technologies, such as chemical precipitation, biosorption has advantages of high efficiency and low operational cost (Volesky, 2003; Farooq et al., 2010). Biosorption involves complex mechanisms of adsorption and ion exchange with sorbing sites on the cell surface (Volesky and Holan, 1995).

\subsubsection{Biosorbent materials}

Biosorbents are mainly fall into the following categories: bacteria, fungi, algae, plants, industrial wastes, agricultural wastes and other polysaccharide materials (Farooq et al., 2010). The capabilities of live microorganisms to adsorb metallic ions have been examined (Wang et al., 2010), however, living organisms are subject to the toxic effect of heavy metals. Once the concentration of metal ion adsorbed by living organisms becomes too high, the organism's metabolism would be disrupted, thus causing the organism to die (Osman et al., 2010). Therefore, biosorbents usually are inactivated through various pre-treatment methods.

The living cells can be inactivated by physical pre-treatment using heat treatment (Maheswari and Murugesan, 2011), autoclaving and vacuum drying (Huang et al., 1988), chemical treatment with acids, alkali, detergents, or organic solvents (Bajwa et al., 2009), or mechanical disruption (Yakubu and Dudeney, 1986). The pre-treatment may enhance or reduce the metal uptake of the biomass dependent on various factors, including: the number of sites in the biosorbent material, the accessibility of the sites, the chemical state of the site, and affinity between site and metal 
(i.e., binding strength) (Vieira and Volesky, 2000). Doan et al. (2008) investigated the effect of the pre-treatment of wheat straw on the removal of $\mathrm{Zn}^{2+}$ and $\mathrm{Ni}^{2+}$ binary in a fixed-bed adsorber. They showed that the removal percentage of $\mathrm{Zn}^{2+}$ ions increased from $47 \%$ to $61 \%$ by immersing dried wheat straw in a $\mathrm{H}_{2} \mathrm{SO}_{4}$ solution for about 30 minutes. Similarly, Huang and Huang (1996) studies showed that acid-washing process produced better adsorption capacity over other treatments. This treatment would dissolve polysaccharide components in the outer cell wall layer of the biosorbent, thus producing additional binding sites. In the present study acid treatment using sulphuric acid was used to enhancing activity of the biomass.

One of the challenges in biosorption studies is the selection of an appropriate biomass that has certain characteristics for adsorption uses. The main characteristics are the cost, the metal uptake capability and the applicability at various conditions (i.e. $\mathrm{pH}$ and temperature) (Vieira and Volesky, 2000). Tables 4 to 8 show various biosorbents used to remove heavy metals

Table 4: Bacterial biosorbent used for metal removal

\begin{tabular}{|l|l|l|l|}
\hline Sorbent & Contaminate (ion) & Uptake (mg/g) & References \\
\hline Aphanotheceh alophytica & $\mathrm{Zn}$ (II) & 13.0 & $\begin{array}{l}\text { Incharoensakdi and } \\
\text { Kitjaharn, 2002 }\end{array}$ \\
\hline Streptomyces rimosus & $\mathrm{Fe}$ (III) & 22.0 & Selatnia et al., 2004 \\
\hline Aeromonas caviae & $\mathrm{Cd}$ (II) & 55.32 & Loukidou et al., 2004 \\
\hline $\begin{array}{l}\text { Corynebacterium } \\
\text { glutamicum }\end{array}$ & $\mathrm{Pb}$ (II) & 67.7 & Choi and Yun, 2004 \\
\hline Pseudomonas sp. & $\mathrm{Cd}$ (II) & 78.0 & Ziagova et al., 2007 \\
\hline Bacillus thuringiensis & $\mathrm{Ni}$ (II) & 45.9 & Oztürk, 2007 \\
\hline
\end{tabular}

Table 5: Yeast (in various forms) biosorbent used for metal removal

\begin{tabular}{|l|l|l|l|}
\hline $\begin{array}{l}\text { Source or from bio- } \\
\text { sorbent }\end{array}$ & Contaminate (ion) & Uptake $(\mathbf{m g} / \mathbf{g})$ & References \\
\hline S.cerevisiae & $\mathrm{Cu}(\mathrm{II})$ & 4.93 & Bakkaloglu et al., 1998 \\
\hline Free cells & $\mathrm{Zn}$ (II) & 23.4 & Al-Saraj et al., 1999 \\
\hline $\begin{array}{l}\text { Ethanol treated waste } \\
\text { baker's yeast }\end{array}$ & $\mathrm{Cd}$ (II) and $\mathrm{Pb}$ (II) & 15.63 and 17.5 & Goksungur et al., 2005 \\
\hline
\end{tabular}


Table 6: Fungal biosorbent for metal removal

\begin{tabular}{|l|l|l|l|}
\hline Species of Fungi & Contaminate (ion) & Uptake (mg/g) & References \\
\hline A.niger & $\mathrm{Cu}(\mathrm{II})$ & 7.22 & Rao et al., 1993 \\
\hline R.arrhizus & $\mathrm{Cr}(\mathrm{VI})$ & 9.02 & Prakasham et al., 1998 \\
\hline R.nigricans & $\mathrm{Cr}(\mathrm{III})$ & 47 & $\begin{array}{l}\text { Bai R and Abraham, } \\
2001\end{array}$ \\
\hline $\begin{array}{l}\text { Penicillium. } \\
\text { chrysogenum }\end{array}$ & $\mathrm{Cr}$ (III), Ni (II) & $27.2,13.2$ & Tan and Cheng, 2003 \\
\hline
\end{tabular}

Table 7: Seaweed biosorbent for metal removal

\begin{tabular}{|l|l|l|l|}
\hline Seaweed Type & Contaminate (ion) & Metal Uptake (mg/g) & References \\
\hline Gracilaria fisheri & $\mathrm{Cd}(\mathrm{II})$ and $\mathrm{Cu}(\mathrm{II})$ & 71 and 46 & Chaisuksant, 2003 \\
\hline Sargassum sp. & $\mathrm{Cr}(\mathrm{III})$ & 68 & Cossich et al., 2004 \\
\hline Ascophyllum nodosum & $\mathrm{Cd}(\mathrm{II})$ & 71.9 & Lodeiro et al, 2006 \\
\hline Bifurcaria bifurcata & $\mathrm{Cd}(\mathrm{II})$ & 61 & Lodeiro et al., 2006 \\
\hline
\end{tabular}

Table 8: Plant sorbent for metal removal

\begin{tabular}{|l|l|l|l|}
\hline Plant sorbet & Contaminate (ion) & Metal Uptake (mg/g) & References \\
\hline Spend grain & $\mathrm{Cd}(\mathrm{II})$ and $\mathrm{Pb}(\mathrm{II})$ & 17.3 and 35.5 & Low et al., 2000 \\
\hline $\begin{array}{l}\text { Sawdust (Pinus } \\
\text { sylvestris) }\end{array}$ & $\mathrm{Cd}(\mathrm{II})$ and $\mathrm{Pb}(\mathrm{II})$ & 9.78 and 9.25 & $\begin{array}{l}\text { Taty-Costodes, } \text { et al., } \\
\text { 2003 }\end{array}$ \\
\hline rice husk & $\mathrm{Cd}(\mathrm{II})$ & 17 & $\begin{array}{l}\text { Kumar and } \\
\text { Bandyopadhyay, 2006 }\end{array}$ \\
\hline chaff & $\mathrm{Cu}(\mathrm{II})$ and $\mathrm{Pb}(\mathrm{II})$ & 14.82 and 50.12 & Han, et al. 2006b \\
\hline
\end{tabular}

By comparing the results obtained for different biosorbent, it is very difficult to conclude one type of biosorbent as the most suitable material in biosorption process. For example, microbial biosorbents are basically small particles, with low density, poor mechanical strength and little rigidity. Even though they have merits, such as high biosorption capacity, they often suffer several drawbacks. The most important include solid-liquid separation problems, possible biomass swelling, inability to regenerate/reuse and development of high pressure drop in the column mode (Vijayaraghavan and Yun, 2008). Agricultural materials usually play an important role due to being widely and easily produced. For example, in Canada wheat straw is abundant, which makes it cost-effective and economical to be material used for biosorption (Wan Ngah and Hanafiah, 2008). 
Wheat straw comprised of about $40 \%$ cellulose, which is a natural biopolymer with ion-exchange property. This makes wheat straw a potentially good biosorbent for the treatment of wastewater containing heavy metal ions (Lawther et al., 1995). Furthermore, microorganism based and other biomasses often need to be cultured and/or tediously prepared before they can be used as biosorbents for metal ions. This would increase the cost of the overall wastewater treatment process. On the other hand, wheat straw could provide an economical source of biosorbent for the metal removal since it can be used directly without elaborated preparation (Doan et al., 2008; Tan and Xiao, 2009).

\subsection{Mechanism of metal biosorption}

Many researchers have tried to provide a solid understanding of the mechanism underlying microbial biosorption of heavy metals. According to Volesky (2003), biosorption mechanism can be classified as physico-chemical interaction between the metal and sorbing sites on the biomass surface. The microbial biosorption of a heavy metal may occur by any or a combination of complexation, coordination, ion exchange and physical adsorption, but ion exchange often dominates the whole adsorption process.

\subsubsection{Physical adsorption}

Metal ion removal from a solution may take place through physical adsorption by van der Waals forces between the metal ion and activated groups. Tsezos and Volesky (1982a and b) reported that thorium and uranium biosorption by Rhizopus arrhizus (fungal biosorbent) was partially by physical adsorption. Physical adsorption was also considered the dominant factor for nickel, zinc, cadmium, lead (Fourest and Roux, 1992) and copper (Zhou and Kiff, 1991) biosorption. 


\subsubsection{Complexation}

Complexation is defined as the complex formation of a species by the association of two or more species (Kotrba et al., 2011). Metal ion adsorption may also take place through complex formation on the cell surface where metal ions can bind to a single ligand (Kotrba et al., 2011). The research on biosorption of thorium and uranium by Rhizopus arrhizus also confirmed that the biosorption process was a combination of physical adsorption and complex formation, where metals coordinated with nitrogen of the chitin cell wall network (Tsezos and Volesky, 1981a and b). Similarly, complexation mechanism was detected in removal of calcium, magnesium, cadmium, zinc, copper and mercury accumulation by Pseudomonas syringae (Cadral, 1992).

\subsubsection{Coordination}

In coordination, the metal acts as a lewis acid that tends to acquire electrons to reach an inert state, and the ligand acts as a lewis base that can share its electron pairs with the metal (Lee Kang et al., 2012). The difference between coordination and complexation is on number of binding. A complex is a metal and ligands, but a coordination compound can have more than one complex (Kotrba et al., 2011). When the central metal atom of a complex is bound to surrounding atoms by covalent bonds with non-mental atoms, the non-metal atom is called the coordinating atom and the bond between non-mental and metal components (atoms) is called coordinate bond (Lee Kang et al., 2012). Aksu et al. (1992) demonstrated that biosorption of copper by Chara vulgaris and Zoogloea ramigera was by both physical adsorption and coordination bonding between metals and amino and carboxyl groups of cell wall polysaccharides.

\subsubsection{Ion-exchange}

Generally, cell wall of microorganism contains polysaccharides, and bivalent metal ions exchange with counter ions of the polysaccharides (Schneider et al., 2001). Kuyucak and 
Volesky (1988) examined the uptake mechanism of copper, zinc, cadmium, uranium by Sargaassum natans and Ascophyllum nodosum. It was shown these ions could exchange with ions such as $\mathrm{Zn}^{2+}, \mathrm{Cd}^{2+}$ and $\mathrm{Co}^{2+}$ resulting in the biosorption uptake of the heavy metals. Correspondingly, the biosorption of copper by fungi Ganoderma lucidium was found to be based on ion exchange mechanism (Muraleedharan and Venkobachar, 1990).

\subsection{Factors affecting biosorption process}

The effect of temperature, solution $\mathrm{pH}$, initial metal concentration and the presence of other ions are the frequently investigated parameters in biosorption studies. These factors are introduced briefly below.

\subsubsection{Effect of temperature}

Temperature is an important parameter for the sorption of metal ions, which deals with the thermodynamics of the biosorption process. Temperature would affect a number of factors in metal ions biosorption. Some of the factors include: 1) stability of the metal ion species initially placed in solution, 2) stability of micro-organism-metal complex depending on the biosorption sites and 3) micro-organism cell wall configuration (Bedell and Darnall, 1992). The effect of temperature on biosorption depends on the adsorption heat (enthalpy change).

For physical adsorption, if the adsorption heat $\Delta \mathrm{H}^{0}<0$, the adsorpion reaction is exothermic, and the capacity decreases with increasing temperature (Kapoor and Viraraghavan, 1997). The decrease in biosorption capacity at higher temperature may be due to the damage of active binding sites on the biosorbent surface (Özer and Özer, 2003). Baig et al. (2009) investigated the effect of temperature on the removal of $\mathrm{Zn}^{2+}$ and $\mathrm{Ni}^{2+}$ binary ions by wheat straw. The authors reported that the biosorption capacity decreased from 10.2 to $4.4 \mathrm{mg} \cdot \mathrm{g}^{-1}$ for zinc and 5.2 to 3.6 
$\mathrm{mg} \cdot \mathrm{g}^{-1}$ for nickel when the temperature was increased from 20 to $40^{\circ} \mathrm{C}$. Similar results were obtained by Kalavathy et al. (2005). Their study showed a decrease in biosorption capacity of rubber wood sawdust from 3.168 to $2.102 \mathrm{mg}^{-\mathrm{g}^{-1}}$ with the increase in temperature from 20 to $40^{\circ} \mathrm{C}$.

On the other hand, if biosorption is considered to be controlled only by chemisorption, $\Delta \mathrm{H}^{\mathrm{o}}>0$, the adsorption reaction is endothermic and favoured at higher temperature (Kotrba et al., 2011). Goyal et al. (2003) found that the metal uptake of Cr (VI) by Saccharomyces cerevisiae increased with temperature in the range of $25-45^{\circ} \mathrm{C}$. Muhamad et al. (2009) observed a slight increase in metal uptake of $\mathrm{Cd}^{2+}$ and $\mathrm{Cu}^{2+}$ by wheat straw with increases in temperature $\left(20-40^{\circ} \mathrm{C}\right)$.

\subsubsection{Effect of $\mathrm{pH}$}

The solution $\mathrm{pH}$ is another important factor in removal of heavy metals by biosorption. The solution $\mathrm{pH}$ strongly influences the ionization of the functional groups present on a biosorbent surface. The $\mathrm{pH}$ controls the interaction between cationic metallic species (i.e. $\mathrm{Zn}^{2+}$ and $\mathrm{Ni}^{2+}$ ions) and negatively charged functional groups on the biosorbent surface. Additionally, $\mathrm{pH}$ affects the solution chemistry: hydrolysis, complexation by organic and/or inorganic ligands, redox reactions and precipitation (Esposito et al., 2002). Many researchers have reported that biosorption uptake capacity increased with increasing $\mathrm{pH}$, but too high $\mathrm{pH}$ values would cause precipitation of metal complexes. Antunes et al. (2003) studied research on $\mathrm{Cu}^{2+}$ biosorption by Sargassum sp. and pointed out an increase in the metal uptake at $\mathrm{pH}$ from 2.0 to 3.0. Similarly, Doan et al. (2008) showed that biosorption of $\mathrm{Zn}^{+2}$ and $\mathrm{Ni}^{+2}$ binary by wheat straw increased with increases in the solution $\mathrm{pH}$ from 4.0 to 7.0 . The $\mathrm{pH}$ value above 7 was avoided during biosorption process because $\mathrm{Zn}^{2+}$ ions started to precipitate. Likewise, Saeed et al. (2005b) 
reported a sharp increase in the removal of lead, cadmium, copper, nickel and zinc by black gram husk at $\mathrm{pH}$ from 2 to 4 and a more moderate trend with further increases in $\mathrm{pH}$ from 4 to 7.0.

\subsubsection{Effect of initial metal concentration}

Another important factor is the initial metal concentration. Generally, metal uptake capacity increases with increasing initial metal concentration. This is due to fact that initial concentration provides a driving force to overcome all mass transfer resistances of the metal ions transport between the solution and the surface of the biomass. Hence, a high initial concentration provides a high driving force for the adsorption process. On the other hand, increase in initial concentration leads to faster saturation of the biomass. El-Sayed et al. (2010) shows that the metal uptake of $\mathrm{Ni}^{2+}$ and $\mathrm{Cd}^{2+}$ binary by biosorption onto rice straw increased as the initial concentration increased from 40 to $1000 \mathrm{mg} . \mathrm{L}^{-1}$. They reported that the adsorption capacity of $\mathrm{Ni}^{2+}$ increased from $3 \mathrm{mg} / \mathrm{g}$ to $19 \mathrm{mg} / \mathrm{g}$ as initial concentration increased from 40 to $1000 \mathrm{mg} \cdot \mathrm{L}^{-1}$.

\subsubsection{Effect of presence of other ions}

Generally, wastewater contains more than one type of metal ions. Studies indicated that the presence of different ions would generally impact the ions of interest accumulation (Suh and Kim, 2000). This is due to competitive adsorption of heavy metals on the surface of the biomass.

Suh and Kim (2000) showed that $\mathrm{Pb}^{2+}$ uptake capacity by Saccharomyces. cerevisiae was reduced significantly from 0.22 to $0.02 \mathrm{mmol} \mathrm{Pb}^{2+} \mathrm{g}^{-1}$ as the concentration of $\mathrm{Hg}^{2+}$ increased.

Similarly, Önal et al. (2007) compared competitive biosorption of $\mathrm{Cr}^{6+}, \mathrm{Cd}^{2+}$ and $\mathrm{Co}^{2+}$ by Chryseomonas luteola TEM 05 cells to single metal ion adsorption. Results showed the metal uptake of single metals ions was always higher in multi-components systems. 


\subsection{Wastewater treatment using a fixed-bed column reactor}

Most of the earlier investigations on heavy metal biosorption were restricted to batch equilibrium studies. Metal removal in a batch operation generally led to an inefficient utilization of the adsorption capacity of the adsorbent. This is due to the decrease of the solute (metal) concentration as the adsorption process progresses (Kotrba et al., 2011). However, in a continuous operation the adsorbent is permanently in contact with fresh metal solution, and therefore, highly efficient utilization of the adsorbent is generally achieved (Da Costa et al., 1996; Saha et al., 2012). Continuous adsorption of metal ions from a solution can be accomplished by employing different types of reactor configurations, including: 1) fixed bed column, 2) fluidized bed column and 3) completely mixed sorption column (Volesky, 2003). Among them, fixed bed column has been more extensively used, owing to its high operational yield and the relative ease of scaling up procedures to industrial capacities (Vieira and Volesky, 2000; Vijayaraghavan and Yun, 2008). Additionally, a fixed bed column is an effective unit for cyclic sorption/desorption process (Vijayaraghavan et al., 2005b).

\subsubsection{Breakthrough curve concept}

Continues biosorption dynamics in a fixed-bed column can be described by a breakthrough curve, which is usually a plot of the concentration ratio $\left(\mathrm{C} / \mathrm{C}_{\mathrm{o}}\right)$ versus the treatment time. A typical sketch of breakthrough curve is presented in Figure 1. The biosorption performance is represented by the area above the curve. Where, $\mathrm{C}$ is the concentration of the adsorbate in the effluent, $\mathrm{C}_{\mathrm{o}}$ is the concentration of the adsorbate in the influent. In the breakthrough curve, the breakthrough time or biosorption service time $\left(\mathrm{t}_{\mathrm{b}}\right)$ represents the duration of an ongoing biosorption process until the effluent concentration $\left(\mathrm{C}_{\mathrm{b}}\right)$ reaches its set effluent concentration, typically a maximum permissible discharge level. The point correlating with the column 
breakthrough is defined as breakthrough point (Hatzikioseyian et al., 1999; Volesky, 2003). In the present study, the defined sorbate concentration in the effluent is $2 \mathrm{ppm}$. Biosorption performance usually evaluated based on biomass metal uptake or biosorprion service time (Volesky, 2003). Once the biosorbent in the column is saturated with the metal ions, the effluent concentration would be the same as the influent concentration; this condition is known as the column exhaustion stage $\left(\right.$ saturation time $\left.=\mathrm{t}_{\mathrm{s}}(\min )\right)$.

In continues adsorption process, when a contaminated water is passed through the bed of adsorbent, a mass transfer zone (MTZ) is formed where continues adsorption of the solute into an adsorbent in the bed occurs. The solute is rapidly adsorbed on the first layer of the bed until the amount adsorbed is in equilibrium with influent contaminate concentration. At this time, the adsorbent is loaded to its maximum capacity, and that portion of bed is exhausted. The overall performance of a flow through sorption column is strongly related to the length of the ionexchange zone that develops during the solid-liquid contact (Hatzikioseyian et al., 1999; Chu, 2004; Srivastava and Goyal, 2010). 


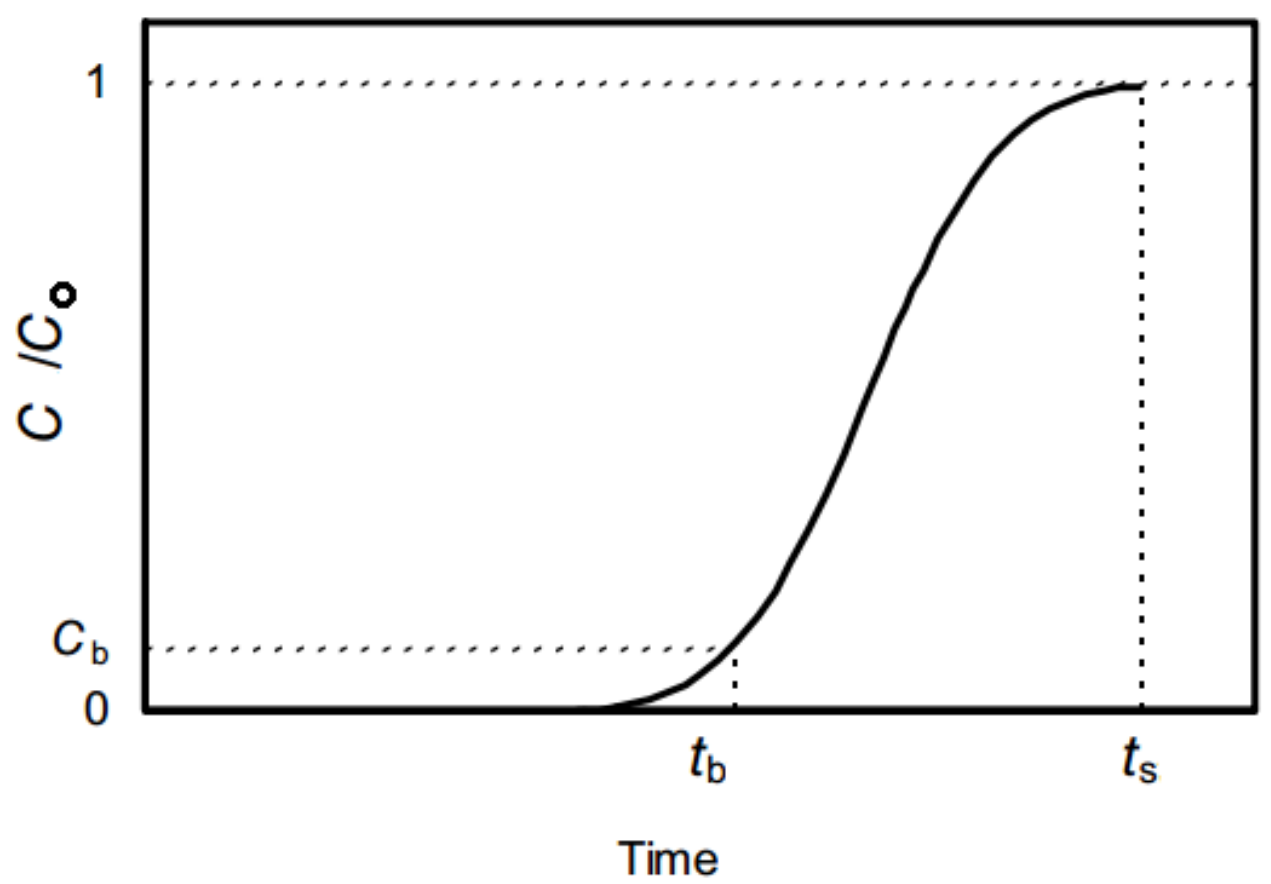

Figure 1: A typical breakthrough curve showing the movement of the adsorption zone, breakthrough and saturation time ${ }^{(\mathrm{Chu}, 2004)}$

\subsection{Factors affecting biosorption in a fixed-bed}

In view of a fixed-bed adsorption column, there are several factors affecting the performance of continue biosorption, including: 1) volumetric flow rate, 2) biosorbent particle size and 3) bed depth.

\subsubsection{Effect of volumetric flow rate}

Volumetric flow rate is an important parameter affecting biosorption of heavy metals in a fixedbed column. Generally, metal uptake of absorbent increases with increases flow rate through the columns. While, the service time decreases with increases flow rate. This behaviour is mainly due to fact that at a low rate of influent, the solute in wastewater has more time to contact with biomass which results in higher service time of heavy metals in column. The increase in adsorption capacity may be explained on the basis of mass transfer fundamentals. The reason is 
that at higher flow rate the rate of mass transfer would increase, i.e. the amount of heavy metals adsorbed onto unit bed depth (mass transfer zone) with an increasing flow rate leads to higher metal uptake (Ko et al., 2000). Many studies reported similar observation (Dursun and Aksu, 2000; Valdman et al. 2001; Texier et al., 2002).

Han et al. (2006b) used chaff to adsorb $\mathrm{Cu}^{2+}$ and $\mathrm{Pb}^{2+}$ binary from aqueous solution in a fixedbed column. It was shown that breakthrough curve occurred faster and service time reduced significantly as the flow rate increased from 3.6 to $8.3 \mathrm{ml} \cdot \mathrm{min}^{-1}$, while uptake capacity increased.

\subsubsection{Effect of biosorbent particle size}

Wang et al. (2006) investigated the impact of rice bran length particle size on biosorption of zinc. The result indicated that sorption capacity increased from 10.56 to $21.07 \mathrm{mg} / \mathrm{g}$ with decreasing particle size from $125-250$ to $<74 \mu \mathrm{m}$. This may be due to the fact that as the particle size decreased the overall surface area for the mass transfer increased (Slejko, 1985). However, if the column packed with extremely small particles, it may reduce the void space inside the biosorbent bed. This would induct poor contact between the influent solution and biosorbent, increase in pressure drop, and further increase risk of clogging (Slejko, 1985).

\subsubsection{Effect of bed depth}

Column bed depth can be defined as the length of the column packing filled with the biosorbent. It is usually considered as one of the critical factors in a fixed bed biosorption process. Many researches confirmed that the service time would increase with an increase in bed depth this is because at a longer bed depth, more binding sites are available for sorption. Similarly, metal uptake increases with increases bed depth. This increase in the adsorption capacity with that in the bed depth can be due to the increased surface area of the sorbent, providing a greater amount 
of availability binding sites for biosorption (Low et al., 1999; Zulfadhly et al., 2001; Texier et al., 2002). Vijayaraghavan et al. (2005a) showed that the service time for adsorption of copper, cobalt and nickel increased as the bed depth increased from 15 to $25 \mathrm{~cm}$.

\subsection{The Bed Depth Service Time (BDST) model}

Many researchers are trying to describe the experimental breakthrough curves using mathematical models. Most of developed models require a preliminary determination of the isotherm and mass transfer parameters (i.e. surface diffusion), which requires additional experimentation and a non-linear curve fitting (Tien, 1994). The mathematical complexity and/or the need to know many parameters from different experiments make these models rather inconvenient for practical use. For that reason, various mathematical empirical models have been developed to predict the dynamic behaviour of the column. In this study, the Bed Depth Service Time (BDST) was used to evaluate the adsorption performance of a fixed-bed column. It is important to note that this model requires no detailed data concerning the characteristics of adsorbate, the type of adsorbent and the physical properties of adsorption bed.

In the fixed bed systems, the main design criterion is to predict how long the adsorbent material will be able to sustain removing a specified amount of impurity from solution before regeneration is needed. This period of time is called the biosorption service time. Hutchins (1973) proposed a simple approach to a fixed bed adsorber to correlate a relationship between bed depth (Z) and service time $\left(t_{b}\right)$, in terms of solute concentrations and adsorption parameters $\left(\mathrm{k}\right.$ and $\left.\mathrm{N}_{\mathrm{o}}\right)$. The model is termed as the bed depth service time (BDST) model.

$t_{b}=\frac{N_{o}}{C_{o} v} Z-\frac{1}{C_{o} k} \operatorname{Ln}\left(\frac{C_{o}}{C_{b}}-1\right)$ 
Where, $t_{b}$ is the biosorption service time $(\min ), Z$ is the bed depth $(m), C_{o}$ is the initial concentration of solute (mg.L $\left.{ }^{-1}\right), C_{b}$ is the set solute concentration in the effluent (i.e., 2 mg- $\mathrm{Zn}$ $\mathrm{Ni} / \mathrm{L}), \mathrm{N}_{\mathrm{o}}$ is the adsorption capacity at $\mathrm{t}_{\mathrm{b}}\left(\mathrm{mg}^{\mathrm{L}} \mathrm{L}^{-1}\right), \mathrm{k}$ is the BDST adsorption rate constant ( $\mathrm{L} . \mathrm{mg}^{-}$ $\left.{ }^{1} \cdot \mathrm{min}^{-1}\right)$, and $\mathrm{v}$ is the superficial velocity of liquid through the column $(\mathrm{m} / \mathrm{min})$. By plotting the service time against the bed depth, the rate constant and the adsorption capacity can be calculated from the intercept and slope of the plot, respectively. Once the model coefficients are known, the model can be used to predict the service time for varied bed depths and solute concentrations in effluent of a large-scale bio-adsorber. The BDST has been widely applied in continues adsorption (Zhao and Duncan, 1998; Jusoh et al., 2007). It is important to note that the BDST typically apply to express the effect of bed depth on breakthrough curves. 


\subsection{Desorption}

Recovery of heavy metals from the sorbents is usually studied with the metal biosorption process. This process is called 'desorption'. This step is to recover bounded metal species for recycling. Also, the metal-laden sorbent can be regenerated for reuse in further treatment cycles. Thus, it helps in reducing the biosorbent replacement cost. In general, the desorption process should:

i. Yield metals in a concentrated form

ii. Restore the biosorbent close to the original conditions for effective reuse

iii. No physical change or damage on sorbing sites

While the regeneration of biosorbent might be accomplished by washing the biomass with an appropriate solution, the type, strength and flow rate of the desorbing solution needed to be determined. Generally, the desorbing agents are classified into three major categories: (i) complexing agents; (ii) competing counter cations; and (iii) proton exchangers (Davis et al., 2000; Hammaini et al., 2007). The metal desorption abilities of the complexing agents depend on their chelating power while counter cations usually act as ion-exchangers to displace the bound metal cations from biosorbents. Similar to the counter ions, proton exchangers donate their protons to recover the bound metal species. Chun-Chiu (2010) studies on recovery of copper ions from wastewater by Micrococcus luteus showed that mineral acids (i.e. sulphuric acid) were more efficient in copper recovery in the fixed-bed desorption process. The effectiveness of desorbing agents in copper recovery was in the following order:

Proton ex-changer $\left(\mathrm{HCl}, \mathrm{HNO}_{3}, \mathrm{H}_{2} \mathrm{SO}_{4},\right)>$ complexing agents $\left(\mathrm{Na}_{2}(\mathrm{EDTA})\right.$ and $\left.\mathrm{Na}_{5} \mathrm{P}_{3} \mathrm{O}_{10}\right)>$ Counter calcium ions $\left(\mathrm{CaCl}_{2}\right.$ and $\left.\mathrm{Ca}\left(\mathrm{NO}_{3}\right)_{2}\right)>$ Counter sodium ions $\left(\mathrm{NaCl}\right.$ and $\left.\mathrm{Na}_{2} \mathrm{SO}_{4}\right)$ 
Similar observations were also reported by other researchers, including: Saeed and Iqbal (2003) and Akhtar et al. (2008).

Fagundes-Klen et al. (2010) carried-out three adsorption/desorption cycles in a fixed-bed column to remove and recover copper ions using $0.1 \mathrm{~mol} / \mathrm{L}$ hydrochloric acid as a desorbing agent. The results showed that an increase in the number of cycles led to a reduction in the adsorption capacity of the alga Sargassum filipendula. This may be due to damages on sorbing sites because of the acidity of desorbing agent as the sorption/desorption cycles continued. 


\subsection{Electroplating of $\mathrm{Zn}^{2+}$ and $\mathrm{Ni}^{2+}$}

The electro-deposition of zinc alloys with group eight metals ( $\mathrm{Ni}$, Co and $\mathrm{Fe}$ ) has attracted interest because of their high corrosion resistance and mechanical properties compared to pure zinc coating (Roventi et al., 2000). In particular, developing and studying of $\mathrm{Zn}-\mathrm{Ni}$ alloy coatings for improving the corrosion resistance of steel has been growing worldwide, and it is considered as a substitute for toxic and high cost cadmium coating (Bajat et al., 2000; Beltowska-Lehman et al., 2002).

Furthermore, since mid- $17^{\text {th }}$ century, the electro-deposition process has been practiced for recovery of concentrated heavy metals from aqueous solutions (Chen, 2004; Lehmberg et al., 2005). The aim of this part of the present research is to recover the concentrated heavy metals from desorption step, using electro-deposition process.

\subsubsection{Working principle of electro-deposition}

A typical electro-deposition cell consists of two electrodes (cathode and anode), electrolyte, external wiring and loads. Each electrode may become either the anode or the cathode depending on the direction of current through the cell (Jüttner et al., 2000; Chen, 2004). When an electrode is immersed in an electrolyte solution, either ions from the electrode will go into the solution or the ions from the solution will deposit onto the electrode. This will be continuing until equilibrium is reached. The potential difference between the electrode and the electrolyte is called galvanic potential (Paunovic and Schlesinger, 1998). Since, the galvanic potential of a single electrode cannot be measured, standard hydrogen electrode is usually used as the reference electrode and its potential is arbitrarily assumed to be zero. The list of the standard electrode potentials of common half-cell reactions in aqueous solution at $25^{\circ} \mathrm{C}$ is given in Appendix $\mathrm{C}$ (Table C-1) (Bret and Bret, 1993). 


\subsection{Anomalous and normal co-deposition}

Depending on the solution composition, different reactions can occur at cathodes and anodes of an electrochemical cell. In the present study, following reactions were likely to take place within the electro-cell since the recovery of binary metal ions from the regeneration step was performed by using electro-deposition technology:

(1) Metal deposition at the cathode:

$$
\begin{array}{ll}
Z n^{2+}(a q)+2 e^{-} \leftrightarrow Z n(s) & E^{o}=-0.76 V \\
N i^{2+}+2 e^{-} \leftrightarrow N i(s) & E^{o}=-0.23 V
\end{array}
$$

(2) Side reactions at the cathode surface such as water hydrolysis decomposition, oxygen reduction and hydrogen evolution:

$$
\begin{array}{ll}
2 \mathrm{H}_{2} \mathrm{O}+2 e^{-} \leftrightarrow \mathrm{H}_{2}+2 \mathrm{OH}^{-} & E^{o}=-0.83 \mathrm{~V} \\
\mathrm{O}_{2}+4 \mathrm{H}^{+}+4 e^{-} \leftrightarrow 2 \mathrm{H}_{2} \mathrm{O} & E^{o}=+1.23 \mathrm{~V} \\
2 \mathrm{H}^{+}+2 e^{-} \leftrightarrow \mathrm{H}_{2} & E^{0}=0.00 \mathrm{~V}
\end{array}
$$

Generally, during a normal co-deposition of two metals, the metal with a higher standard reduction potential would deposit on the cathode more than the other metal with a lower standard reduction potential. According to the standard half-cell potential of $\mathrm{Zn}^{2+}(-0.76 \mathrm{~V})$ and $\mathrm{Ni}^{2+}(-$ $0.23 \mathrm{~V}$ ) (Appendix $\mathrm{C}$, Table $\mathrm{C}-1$ ), $\mathrm{Ni}^{2+}$ should deposit on the cathode more readily than $\mathrm{Zn}^{2+}$. However, many researchers who studied the electrolytic co-deposition of zinc and nickel from a solution noticed that the less noble metal, zinc in this case, deposited more readily than the more noble metal (Elkhatabi et al., 1999; Roventi et al., 2000). This behaviour is called anomalous codeposition (Brenner, 1963). 
Although the anomalous co-deposition of Zn-Ni alloys has been known since 1907, the codeposition mechanisms are not well understood and there is still no universally accepted theory. Several researchers have attempted to interpret the mechanism of the anomalous co-deposition. The first attempt was proposed by Brenner (1963), which was called the "additional agent theory". This theory suggested that the additionally agent is produced by the cathode reaction only when the current density is high enough to increase significantly the $\mathrm{pH}$ of the cathode diffusion layer. A thin layer of zinc hydroxide at the cathode surface inhibits formation of $\mathrm{Ni}$ deposits. This layer is formed due to a rise in $\mathrm{pH}$ in the cathode layer, caused by hydrogen evolution during the deposition process.

A second theory was introduced by Dahmas and Croll (1965), who conducted a comprehensive investigation on the role of $\mathrm{pH}$ at the cathode surface and its effect on anomalous co-deposition of iron-nickel alloys. They demonstrated that when the rate of hydrogen evolution increased at $\mathrm{pH}$ higher than the critical $\mathrm{pH}$ at the cathode surface resulting in the formation of ferrous hydroxide. A layer of ferrous hydroxide at the cathode blocked nickel deposit but permitted a high rate of iron deposit. After Dahms and Chroll introduced their theory, other researchers used the hydroxide suppression theory to explain the co-deposition for other systems like zinc and cobalt (Higashi et al., 1981).

Although the anomalous co-deposition is mostly expected to take place with $\mathrm{Zn}-\mathrm{Ni}$ deposition, but it is not always the case. Changing the operational parameters, especially the current density, has a significant effect on the behaviour of the deposition process. Fedrizzi et al. (1992) reported that at low current densities, transition from anomalous to normal co-deposition occurred. This may be due to the fact that at a high current density, more water would be hydrolyzed according 
to reaction $(\mathrm{R} 3)$, producing $\mathrm{OH}^{-}$for the formation of zinc hydroxide at the cathode surface. This would limit the sites on the electrode that are available for $\mathrm{Ni}^{2+}$ deposition. On the other hand, at low current density, metals in the solution would be in their ionic forms since the critical $\mathrm{pH}$ for the formation of both zinc hydroxide and nickel hydroxide was not reached. Thus, $\mathrm{Ni}^{2+}$ would be deposited more favourably than $\mathrm{Zn}^{2+}$ due to its higher standard reduction potential (Bret and Bret, 1993; Crow, 1998). Similar results were also observed by other researchers (Benballa et al., 2000). 


\section{Chapter Three: Experimental methods}

This section is divided into four parts: biosorbent pre-treatment, biosorption, desorption and electro-deposition processes. The equipment requirements for the processes are listed separately.

\subsection{Biosorbent pre-treatment}

Wheat straw was obtained from a farm in King City, North of Toronto, Ontario, Canada. The raw wheat straw was cut into four particle sizes of $0.5,1.0,1.5$, and 2.0 inches $(1.27,2.54,3.81$ and $5.08 \mathrm{~cm}$ ). Before being used in the experiments, wheat straw was pre-treated using the following steps. This pre-treatment step was recommended for the biosorption of heavy metals using plant sorbent as reported in the literature (Muhamad et al., 2009; Alam et al., 2012).

1. Washing wheat straw with distilled water about 5 minutes

2. Drying wheat straw at $60^{\circ} \mathrm{C}$ until the wheat straw weight was unchanged

3. Immersing dried wheat straw into a $0.1 \mathrm{~N}$ sulphuric acid $\left(\mathrm{H}_{2} \mathrm{SO}_{4}\right)$ solution for a half an hour

4. Washing the treated sample with distilled water until the residual $\mathrm{pH}$ was about 7.0

5. Drying the neutralized sample at $60^{\circ} \mathrm{C}$ until achieving a constant weight.

\subsection{Biosorption in a fixed-bed column}

Continuous biosorption experiments were carried out using two equal-length columns of a 0.0508 $\mathrm{m}$ inner diameter and a $1.5 \mathrm{~m}$ height, as shown in Figure 2. A 3-cm thick fiber meshes were placed on top and bottom of the packed beds of wheat straw in the columns for better flow distribution. In order to maintain a consistent packing porosity in the columns, the columns were packed with $65 \mathrm{~g}$ of wheat straw for every $0.5 \mathrm{~m}$ of the column height. The metal ion solution was continuously pumped from a feed tank to bottom of the column. Zinc sulphate and Nickel sulphate (VWR, Mississauga, ON, Canada) were used to prepare $\mathrm{Zn}^{2+}$ and $\mathrm{Ni}^{2+}$ binary mixture used in the experiments. The volumetric flow rate of the liquid was measured by a flow-meter (F- 
440 Polysulfone Flow-meter, 0.05-1 L/min). The treated wastewater samples were collected at 5 minutes interval for the first 2.5 hours, and 30 minutes for the rest of the experiment. The residual metal concentrations in the samples were measured using an atomic adsorption spectrophotometer (model Analyst 800, Perkin Elmer, Massachusetts, USA). The experiments were performed at room temperature $\left(23^{\circ} \mathrm{C}\right)$ with the solution $\mathrm{pH}$ adjusted to 7.0 using a $0.1 \mathrm{~N}$ potassium hydroxide (KOH) (Doan et al., 2008; Baig et al., 2009). The total run time for each experiment was 7 hours.

The quantity of metal adsorbed $\left(\mathrm{M}_{\mathrm{ad}}\right)$ was calculated by multiplying the area above the breakthrough curve with the liquid volumetric flow rate and initial concentration. The total amount of metal ions that entered the column was calculated as below:

$M_{\text {total }}=C_{o} \cdot Q \cdot t_{s}$

Where $C_{o}$ is initial concentration, $Q$ is liquid volumetric flow rate and $t_{s}$ is saturation time (min), which is defined as when $\mathrm{C} / \mathrm{C}_{\mathrm{o}}=1$ in the breakthrough curve. The percentage metal removal was then calculated as:

Removal $(\%)=\frac{M_{a d}}{M_{\text {Total }}} \times 100$ 

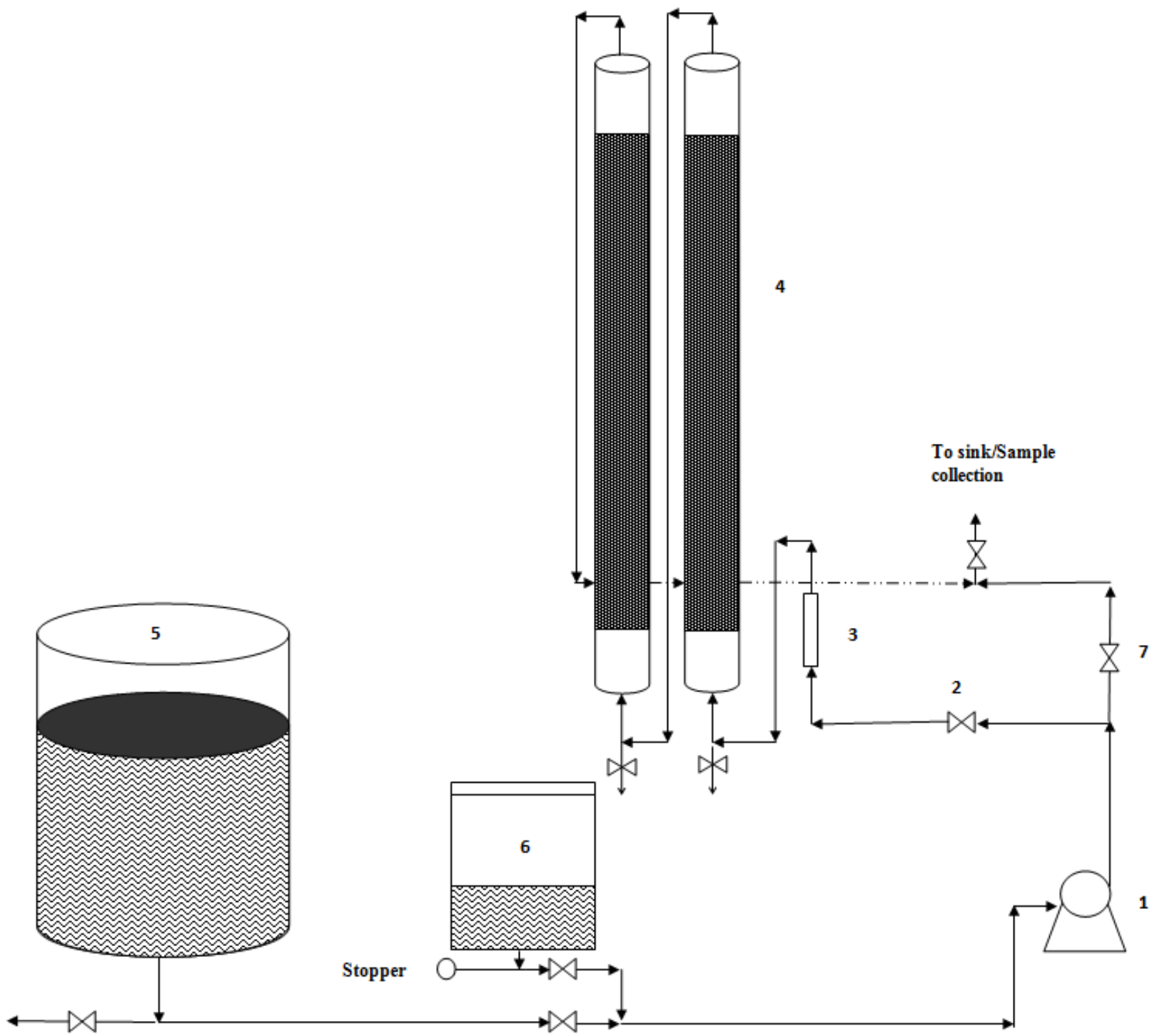

Figure 2: Biosorption experimental setup: 1) pump, 2) valve, 3) flow meter, 4) adsorption columns, 5) metal ion solution feed tank, 6) desorbing agent feed tank, 7) by-pass valve for desorption process

\subsubsection{Biosorption and experimental design}

Biosorption efficiency in a continuous system depends on numerous factors, such as: initial metal concentration, volumetric flow rate, bed depth and biosorbent particle size. Practically, in a wastewater treatment system each factor and interactions of the factors may influence the biosorption performance (Kumar et al., 2009). However, treating each factor separately would be 
very time-consuming. To overcome this difficulty, response surface methodology (RSM) can be employed to determine the best operational conditions of a fixed-bed column performance with minimum experimental runs. The RSM is a collection of mathematical and statistical techniques useful for the modeling and analysis of problems in which a response of interest is influenced by several variables and the objective is to determine the best operational conditions (Montgomery, 2005). The RSM has already been successfully applied in several fields, such as: food processing, biochemical engineering and adsorption processes for optimization (Bahadir and Rauf, 2008; Frišták et al., 2012).

In this study, Central Composite Faced-center (CCF) model, which is the standard RSM, was established on the basis Design Expert Software (Stat Ease, Version 8.0.1) for determination the best set operational conditions of a fixed-bed column. The objective was to maximize the biosorption service time for $\mathrm{Zn}^{2+}$ and $\mathrm{Ni}^{2+}$ binary solution, which service time is defined as the length of time to reach a specific effluent concentration. In this study, $2 \mathrm{mg} / \mathrm{L}$ is the limit for the heavy metal discharge. The CCF design is highly recommended design for pilot plant and full scale investigations, particularly widely applied in continuous adsorption research (Box and Draper, 1987; Eriksson et al., 1999-2008).

To improve biosorption process, several parameters, including: bed depth $(0.5-2 \mathrm{~m})$, volumetric flow rate $(0.1-0.5 \mathrm{~L} / \mathrm{min})$, initial metal concentration $(10-50 \mathrm{mg} / \mathrm{L})$ and biosorbent particle size (0.5-2 inch) were studied. However, the effect of the particle size was investigated separately from the other factors. Therefore, in the present study three most profound factors, bed depth, volumetric flow rate and initial metal concentration were used in the CCF design. Table 9 presents the selected interval of each factor (the minimum and maximum) used in the 
experimental design. The three factorial CCF design consists of 20 experiments with the first 15 experiments organized in a factorial design and experiments 16 to 20 involving the replication of the central point.

Table 9: Experimental factors and levels for the RSM model

\begin{tabular}{|l|l|c|c|c|}
\hline \multirow{2}{*}{ Code } & \multicolumn{1}{|c|}{ Name of Factor } & \multicolumn{3}{|c|}{ Factor Levels } \\
\cline { 3 - 5 } & & -1 & 0 & 1 \\
\hline A & Bed depth (m) & 0.50 & 1.25 & 2.00 \\
\hline B & Volumetric flow rate $\left(\mathrm{L} . \mathrm{min}^{-1}\right)$ & 0.10 & 0.30 & 0.50 \\
\hline C & Initial concentration $\left(\mathrm{mg} . \mathrm{L}^{-1}\right)$ & 10 & 30 & 50 \\
\hline
\end{tabular}

\subsection{Biosorbent regeneration studies}

After the best conditions for the adsorption had been determined from a series of adsorption experiments, those conditions were used in the adsorption step prior to desorption (biosorbent regeneration) of metal-laden biosorbent. The major factors, which influence the desorption process in a fixed bed are the type, strength and flow rate of the desorbing solution. In this study, the effect of hydrochloric acid, nitric acid and sulphuric acid, mineral acids, as desorbing agents at varied concentration $(0.1$ to $0.5 \mathrm{M})$ and flow rates $\left(0.05\right.$ to $\left.0.1 \mathrm{~L}^{\mathrm{min}}{ }^{-1}\right)$ on the biomass regeneration was investigated.

The acid solution was pumped to the top of the column. Prior to the regeneration, in order to remove the residual metal solution in the columns, they were washed with distilled water at a flow rate of $0.1{\mathrm{~L} . \mathrm{min}^{-1}}^{-1}$ until the effluent $\mathrm{pH}$ was about 7.0. During the biosorbent regeneration step, wastewater samples were collected every 5 minutes until no trace of $\mathrm{Zn}^{2+}$ and $\mathrm{Ni}^{2+}$ ions detected from the column effluent. The concentrations of $\mathrm{Zn}^{2+}$ and $\mathrm{Ni}^{2+}$ binary mixture in the samples were measured by using an atomic adsorption spectrophotometer. After the completion 
of the biosorbent regeneration, distilled water was used to wash the bed until the $\mathrm{pH}$ in the washing effluent stabilized near 7.0 before it was put back to the next adsorption/desorption cycle. A number of adsorption/desorption experiments were carried out at different conditions to determine the best conditions for the biosorbent regeneration.

In order to determine the reusability of the biosorbent, the cycle of sorption followed by desorption was repeated five times, using the recycled biosorbent and the best conditions previously obtained. The sorption capacity of the biosorbent was evaluated after each cycle. To determine the biosorbent weight loss after five cycles, the biosorbent was washed with distilled water, dried at $60^{\circ} \mathrm{C}$ overnight and weighed (Chun-Chiu, 2010).

The mass of desorbed metal $\left(\mathrm{M}_{\mathrm{d}}\right)$ can be calculated from the area below the elution curve (metal concentration at the outlet versus time) multiplying with the liquid volumetric flow rate. The elution efficiency (E) was defined as:

$E(\%)=\frac{M_{d}}{M_{a d}} \times 100$

\subsection{Metal recovery by electro-deposition process}

A laboratory-scale electro-cell is shown in Figure 3. In this part of the study, electro-deposition technology was used to recover the heavy metals from the regeneration step. The electro-cell was a plate-in-tank cell of $25 \mathrm{~cm}$ length, $20 \mathrm{~cm}$ wide and $5.5 \mathrm{~cm}$ high. In the electro-cell three 316stainless steel anodes and two aluminum cathodes, $18 \mathrm{~cm} \times 5 \mathrm{~cm}$ each were installed. The gap between each anode and cathode was set at $1.5 \mathrm{~cm}$. A liquid distributor with $0.5 \mathrm{~cm}$ holes was placed at the bottom of the electro-cell to spread out liquid evenly at the cell inlet. An amp-meter (Model 052-0060-2, Master Craft) was placed in series in the electric circuit to monitor the current. A feed tank was filled with an electrolyte solution (the concentrated $\mathrm{Zn}-\mathrm{Ni}$ metals 
solution from biosorbent regeneration), and $1000 \mathrm{ppm}$ of potassium chloride was added, as a supporting electrolyte, to enhance the electric current flow. The electrolyte $\mathrm{pH}$ was maintained at 5.5 - 6.0 over the experiment duration (Simonsson, 1984; Orhan et al., 2002; Doan et al., 2003). Before each run, the electrodes were cleaned by immersing them in a $0.1 \mathrm{M}$ sulphuric acid solution for half an hour and rinsing them with distilled water. Each experiment run took 72 hours. Liquid samples were collected every 10 minutes for the first 12 hours and 30 minutes until the end the experiment. The metal content of the collected samples were analyzed using the atomic adsorption spectrophotometer. The effect of the current density and the liquid flow rate on the metal ion deposition was investigated. The current density and the liquid flow rate were adjusted by controlling the supplied voltage (Model H Filtered D.C. Power Supply) and the bypass valve on the liquid inlet line, respectively.

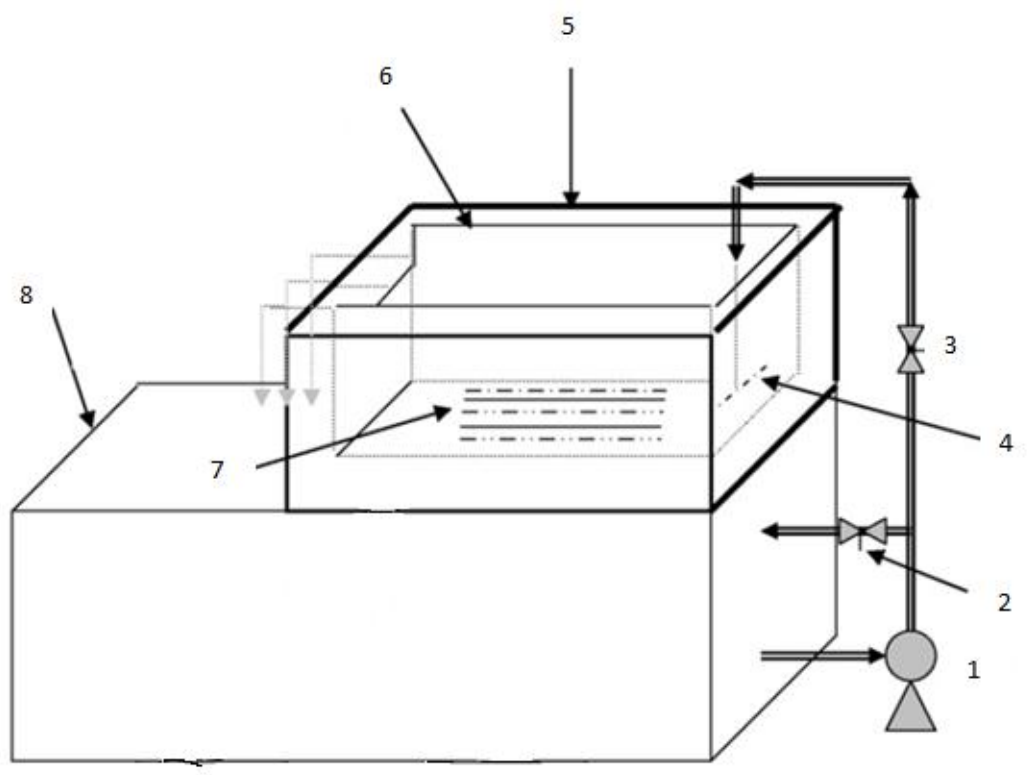

Figure 3: Experiment set up for electro-deposition: (1) pump, (2) by-pass or recycle valve, (3) main stream valve, (4) liquid distributor, (5) water bath, (6) electro-cell, (7) electrode spacer, (8) feed tank 


\subsection{Laboratory equipment}

A list of the instrumentation and laboratory equipment used in this study is shown in Table 10.

Table 10: List of the equipment used in this research

\begin{tabular}{|c|c|c|}
\hline Instrument & Model & Precision (unit) \\
\hline Balance & Model EL-200S, Setra Systems Inc & $\pm 0.001(\mathrm{mg})$ \\
\hline $\mathrm{pH}$ meter & $\begin{array}{c}\text { Model PH 2100e, Mettler Toledo, } \\
\text { Germany }\end{array}$ & \pm 0.01 \\
\hline $\begin{array}{c}\text { Atomic adsorption } \\
\text { Spectrophotometer }\end{array}$ & $\begin{array}{c}\text { Medel-800, Perkin Elemer } \\
\text { Transversely, Massachusetts, USA }\end{array}$ & --- \\
\hline Pump & $\begin{array}{c}\text { Pulsafeeder Mechanical } \\
\text { Diaphragm Pumps, 115/230V, w/ } \\
\text { Mpc Controller }\end{array}$ & $\pm 0.02(\mathrm{~L} / \mathrm{min})$ \\
\hline Flow-meter & $\begin{array}{c}\text { F-440 Polysulfone Flow-meter, } \\
\text { 0.05-1 LPM }\end{array}$ & $\pm 0.01(\mathrm{~L} / \mathrm{min})$ \\
\hline Power Supply & $\begin{array}{c}\text { Model H Filtered D.C. Power } \\
\text { Supply }\end{array}$ & --- \\
\hline Amp-meter & Model 052-0060-2, Master Craft & $\pm 1(\mathrm{~mA})$ \\
\hline Thermometer & VWR Thermometer GNPRP - \\
$20 / 110 \mathrm{C}$ & $\pm 0.1\left({ }^{\circ} \mathrm{C}\right)$ \\
\hline
\end{tabular}

- The $\mathrm{pH}$ of the wastewater was measured by using a $\mathrm{pH}$ meter. It was calibrated on a daily basis using buffer solution of 4, 7 and $10 \mathrm{pH}$. During any experimental run, adjustment to the $\mathrm{pH}$ of the wastewater was done by addition of $0.1 \mathrm{~N}$ potassium hydroxide $(\mathrm{KOH})$.

- The metering-pump used in biosorption and desorption experiments, had a flow meter in a range from 0.01 to $5 \mathrm{~L} / \mathrm{min}$, which was used along with a flowmeter (F-440 Polysulfone Flow-meter, 0.02-1 LPM). The metering pump's flow-meter was calibrated on a daily basis according to the pump instruction manual. 


\section{Chapter Four: Results and Discussion}

\subsection{Effect of biosorbent particle size}

The metal removal rates (for the first 60 minutes at which the biomass was just saturated) for different biosorbent (wheat straw) particle sizes (length) from 0.5 to 2 inches, under a set bed depth of $2 \mathrm{~m}$, volumetric flow rate of $0.5 \mathrm{~L} / \mathrm{min}$ and initial metal concentration of $50 \mathrm{mg}-\mathrm{Zn}-\mathrm{Ni} / \mathrm{L}$ is presented in Figure 4. Average adsorption rate is defined as the ratio of the metal uptake to the operational time of 60 minutes. As can be seen in Figure 4, the biosorbent particle size did not affect the removal rate of both heavy metals significantly. Similar results were also observed at varied bed depth, volumetric flow rate and initial concentration (Figure A-1 and A-2; Appendix A-1). This may be attributed to the fact that wheat straw particles are hollow cylinders with a very thin wall. The surface of the ends of the particle is very small as compared with that of the cylindrical-side surface of the particle. The total surface area of the particle is thus mainly from the cylindrical side. Therefore, the specific area (area per unit mass) of wheat straw didn't change significantly for particle sizes from 0.5 to 2.0 inches. Similar results were also observed by Doan

et al. (2008) on biosorption of $\mathrm{Zn}^{2+}$ and $\mathrm{Ni}^{2+}$ binary ions by wheat straw. In this part of study, the 0.5 inch particle size was selected to use in the subsequent fixed-bed studies. 


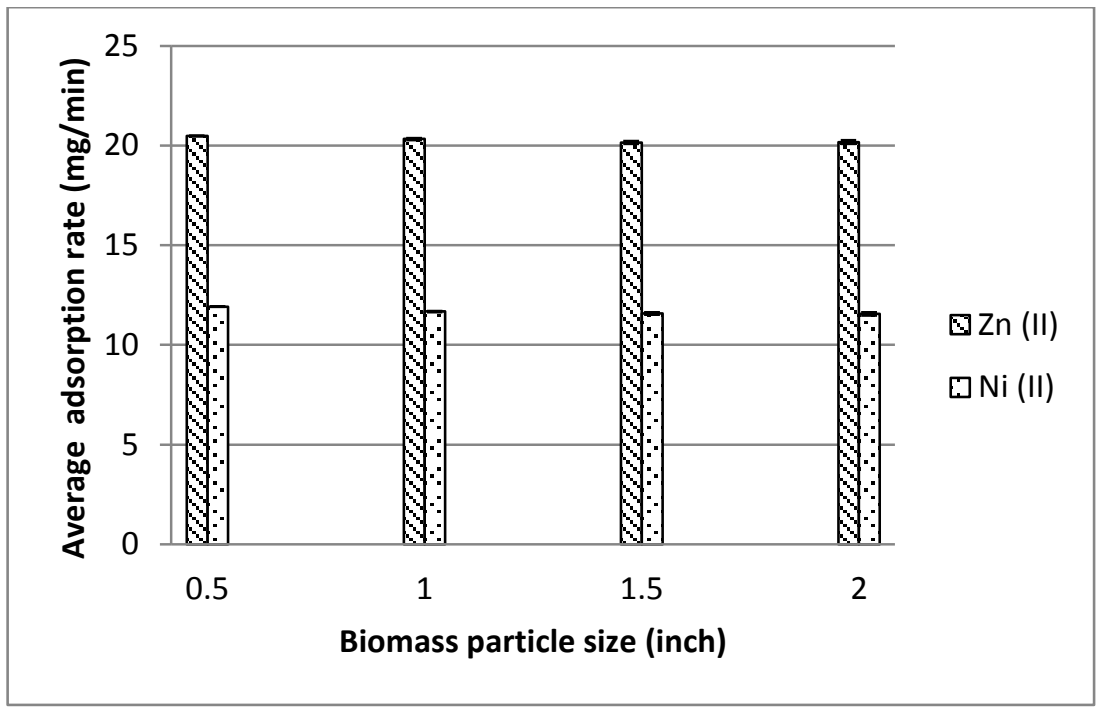

Figure 4: Effect of particle size on biosorption of binary solution $\left(\mathrm{Zn}^{2+}\right.$ and $\left.\mathrm{Ni}^{2+}\right)$ in fixed-bed at bed depth $=2 \mathrm{~m}$; volumetric flow rate $=0.5 \mathrm{~L} / \mathrm{min}$; initial concentration $\left[\mathrm{Zn}^{2+}\right]_{0}=\left[\mathrm{Ni}^{2+}\right]_{0}=50 \mathrm{ppm}(60$ minutes operation time) 


\subsection{Biosorption and experimental design}

The CCF design matrix and the experimental service times for $\mathrm{Zn}^{2+}$ and $\mathrm{Ni}^{2+}$ in binary systems are given in Table 11. The standard deviation $(\sigma)$ was calculated for $\mathrm{Zn}^{2+}$ and $\mathrm{Ni}^{2+}$ (Appendix A, A-2), as \pm 0.09 and \pm 0.09 for $\mathrm{Zn}^{2+}$ and $\mathrm{Ni}^{2+}$, respectively, indicate a good precision of the experimental data.

Table 11: CCF experimental design for adsorption of $\mathrm{Zn}^{2+}$ and $\mathrm{Ni}^{2+}$ binary ions

\begin{tabular}{|c|c|c|c|c|c|}
\hline & \multicolumn{3}{|c|}{ Factors (independent variables) } & \multicolumn{2}{|c|}{ Service Time* $(\min )$} \\
\hline Exp. No & $\begin{array}{l}\text { Bed depth }(\mathrm{A}) \\
(\mathrm{m})\end{array}$ & $\begin{array}{l}\text { Volumetric flow } \\
\text { rate (B) } \\
(\mathrm{L} / \mathrm{min})\end{array}$ & $\begin{array}{c}\text { Initial } \\
\text { concentration }(\mathrm{C}) \\
(\mathrm{mg} / \mathrm{L})\end{array}$ & $\begin{array}{l}\mathrm{Zn}^{2+} \\
\left(\mathrm{Y}_{1}\right)\end{array}$ & $\begin{array}{l}\mathrm{Ni}^{2+} \\
\left(\mathrm{Y}_{2}\right)\end{array}$ \\
\hline 1 & 0.5 & 0.1 & 10 & 18 & 12.2 \\
\hline 2 & 2 & 0.1 & 10 & 87.4 & 67.1 \\
\hline 3 & 0.5 & 0.5 & 10 & 4.88 & 3.12 \\
\hline 4 & 2 & 0.5 & 10 & 23.87 & 16.33 \\
\hline 5 & 0.5 & 0.1 & 50 & 15.3 & 5.4 \\
\hline 6 & 2 & 0.1 & 50 & 33.6 & 16.2 \\
\hline 7 & 0.5 & 0.5 & 50 & 1.6 & 0.6 \\
\hline 8 & 2 & 0.5 & 50 & 13.7 & 5.8 \\
\hline 9 & 0.5 & 0.3 & 30 & 10.0 & 4.0 \\
\hline 10 & 2 & 0.3 & 30 & 32.2 & 10.6 \\
\hline 11 & 1.25 & 0.1 & 30 & 35.0 & 15.4 \\
\hline 12 & 1.25 & 0.5 & 30 & 9.2 & 2.8 \\
\hline 13 & 1.25 & 0.3 & 10 & 47.6 & 19.5 \\
\hline 14 & 1.25 & 0.3 & 50 & 6.3 & 2.1 \\
\hline 15 & 1.25 & 0.3 & 30 & 18.2 & 7.5 \\
\hline 16 & 1.25 & 0.3 & 30 & 18.3 & 7.5 \\
\hline 17 & 1.25 & 0.3 & 30 & 18.4 & 7.4 \\
\hline 18 & 1.25 & 0.3 & 30 & 18.5 & 7.3 \\
\hline 19 & 1.25 & 0.3 & 30 & 18.4 & 7.5 \\
\hline 20 & 1.25 & 0.3 & 30 & 18.3 & 7.3 \\
\hline
\end{tabular}

* Service time: The time span to reach a specific effluent concentration; $\mathrm{C}_{\mathrm{b}}=2 \mathrm{mg} / \mathrm{L} \mathrm{Zn}^{2+} \mathrm{or} \mathrm{Ni}^{2+}$ 
Bases on Table above, the influence of different bed depth, liquid flow rates and inlet metal concentrations on biosorption service time of $\mathrm{Zn}^{2+}$ and $\mathrm{Ni}^{2+}$ can be evaluated.

\subsubsection{Effect of bed depth}

In this study, the pre-treated wheat straws were packed in the fixed bed columns with bed depth (Z) ranging from 0.5 to $2 \mathrm{~m}$. By comparing experiments 9, 10 and 15 in Table 11, the bed depth had a positive effect on the service time for both $\mathrm{Zn}^{2+}$ and $\mathrm{Ni}^{2+}$ binary biosorption. This is mainly due to a higher number of binding sites available for sorption of metal ions with a taller bed, which would lead to a longer service time.

The breakthrough curves for experiments 9, 10 and 15 in Table 11 are displayed in Figures 5 and 6 for $\mathrm{Zn}^{2+}$ and $\mathrm{Ni}^{2+}$, under initial concentration $\left[\mathrm{Zn}^{2+}\right]_{0}=\left[\mathrm{Ni}^{2+}\right]_{0}=30 \mathrm{ppm}$ and volumetric flow rate of $0.3 \mathrm{~L} / \mathrm{min}$. As shown in Figures 5 and 6, when the bed depth was increased, the curve becomes less stiff and the biosorbent takes a longer time to reach the saturation. Table 12 summarizes the performance of biosoption at varied bed depths. The results showed that as bed depth increased from $0.5 \mathrm{~m}$ to $2.0 \mathrm{~m}$, the service time for $\mathrm{Zn}^{2+}$ and $\mathrm{Ni}^{2+}$ increased from 10 min to 32.2 min and 4 min to $10.6 \mathrm{~min}$, respectively. However, the metal uptake per unit mass of wheat straw decreased as bed depth increased. This might due to fact, the concentration potential $(\Delta C)$ in upper section of the bed will decrease significantly as the taller bed depths, which lead to lower overall transfer of metals ions to biomass. Thus, the metal uptake per unit mass reduced as bed depth increased.

Vijayaraghavan et al. (2005a) observed similar results and they reported that the service time for copper, cobalt and nickel ions increased as the bed depth was increased from 15 to $25 \mathrm{~cm}$. Wu 
and $\mathrm{Yu}$ (2008) showed that the breakthrough time of 2,4-dichlorophenol by immobilized Phanerochaete chrysosporium increased with the bed depth.

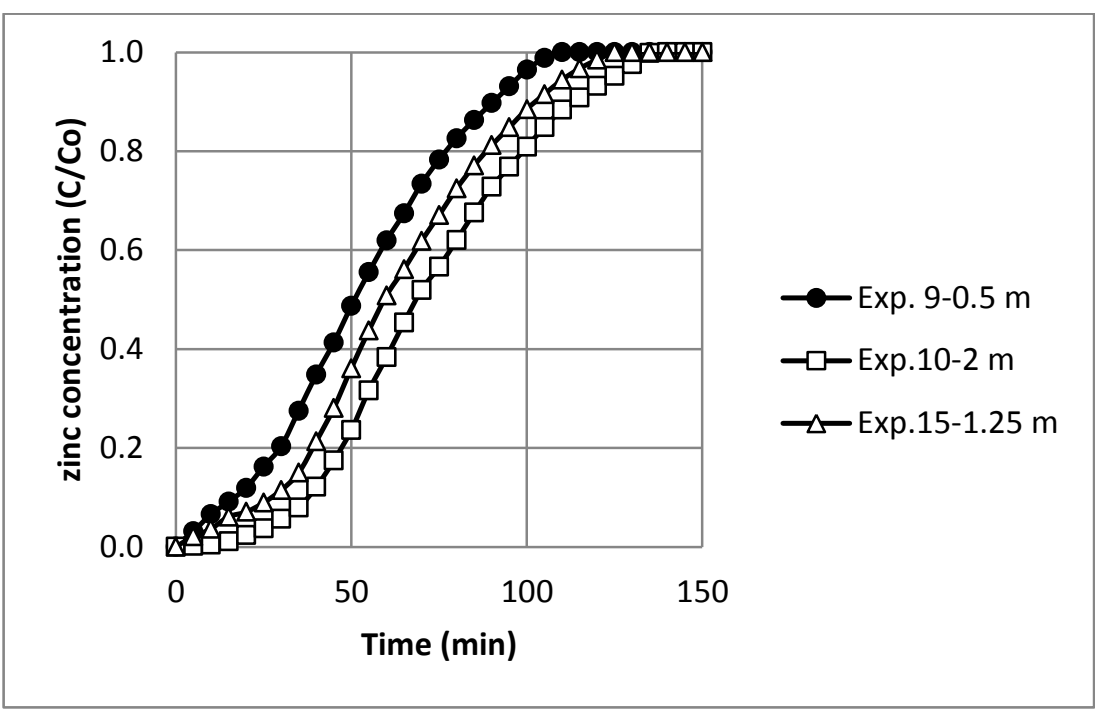

Figure 5: Effect of bed depth on adsorption of $\mathrm{Zn}^{2+}$ in binary solution at volumetric flow rate $=0.3$ $\mathrm{L} / \mathrm{min}$; initial concentration $\left[\mathrm{Zn}^{2+}\right]_{0}=\left[\mathrm{Ni}^{2+]}=30 \mathrm{ppm}\right.$

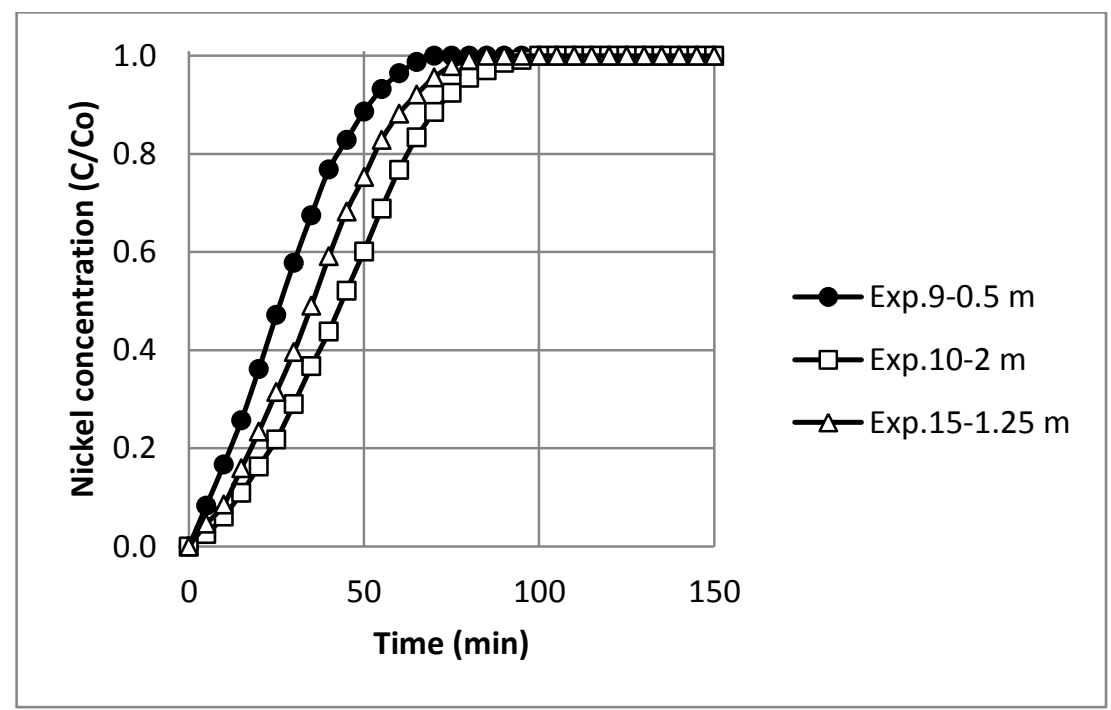

Figure 6: Effect of bed depth on adsorption of $\mathrm{Ni}^{2+}$ in binary solution at volumetric flow rate $=0.3$ $\mathrm{L} / \mathrm{min}$; initial concentration $\left[\mathrm{Zn}^{2+}\right]_{0}=\left[\mathrm{Ni}^{2+}\right]_{0}=30 \mathrm{ppm}$ 
Table 12: $\mathrm{Zn}^{2+}$ and $\mathrm{Ni}^{2+}$ biosorption performances at varied bed depths

\begin{tabular}{|c|c|c|c|c|c|c|c|c|}
\hline \multicolumn{3}{|c|}{ Experimental conditions } & \multicolumn{3}{|c|}{$\mathrm{Zn}^{2+}$} & \multicolumn{3}{|c|}{$\mathrm{Ni}^{2+}$} \\
\hline $\begin{array}{c}\text { Bed } \\
\text { depth } \\
(\mathrm{m})\end{array}$ & $\begin{array}{c}\text { Liquid } \\
\text { flow rate } \\
\left(\text { L.min }{ }^{-1}\right) \\
\end{array}$ & $\begin{array}{c}\text { Inlet } \\
\text { concentration } \\
\left(\mathrm{mg} . \mathrm{L}^{-1}\right)\end{array}$ & $\begin{array}{c}\text { Service } \\
\text { time }^{1} \\
(\mathrm{~min})\end{array}$ & $\begin{array}{c}\text { Removal } \\
\text { percentage } \\
2(\%) \\
\end{array}$ & $\begin{array}{c}\text { Metal } \\
\text { uptake }^{3} \\
\left(\mathrm{mg} \cdot \mathrm{g}^{-1}\right)\end{array}$ & $\begin{array}{c}\text { Service } \\
\text { time } \\
(\min )\end{array}$ & $\begin{array}{c}\text { Removal } \\
\text { percentage } \\
(\%) \\
\end{array}$ & $\begin{array}{c}\text { Metal } \\
\text { uptake } \\
\left(\mathrm{mg}^{\left.-g^{-1}\right)}\right.\end{array}$ \\
\hline 0.5 & 0.3 & 30 & 10.0 & 45.9 & 4.5 & 4.0 & 39.6 & 2.4 \\
\hline 1.25 & 0.3 & 30 & 18.2 & 49.8 & 3.4 & 7.5 & 42.3 & 1.9 \\
\hline 2.0 & 0.3 & 30 & 32.2 & 51.5 & 2.5 & 10.6 & 43.5 & 1.5 \\
\hline
\end{tabular}

${ }^{1}$ Service time: The length of time to reach a specific effluent concentration; $\mathrm{C}_{\mathrm{b}}=2 \mathrm{mg} / \mathrm{L} \mathrm{Zn}^{2+}$ or Ni$^{2+}$

2 The time step for $\%$ removal $=\mathrm{t}_{\mathrm{s}}(\mathrm{min}) ; \mathrm{t}_{\mathrm{s}}$ is saturation time

3 The time step for metal uptake $=t_{s}(\min )$

\subsubsection{Effect of liquid flow rate}

Volumetric flow rate significantly affects the service time of $\mathrm{Zn}^{2+}$ and $\mathrm{Ni}^{2+}$ binary solutions. This independent factor had a negative effect on service time of $\mathrm{Zn}^{2+}$ and $\mathrm{Ni}^{2+}$ ions, as seen in Table 11 (exp. 11, 12, and 15). Figures 7 and 8 represent the trend of the variation in the effluent zinc and nickel concentration against time for the flow rates $0.1,0.3$ and $0.5 \mathrm{~L} / \mathrm{min}$ at the fixed initial concentration of $30 \mathrm{mg} / \mathrm{L}$ and bed depth of $1.25 \mathrm{~m}$.

When the flow rate was increased from 0.1 to $0.5 \mathrm{~L} \cdot \mathrm{min}^{-1}$, the breakthrough curves developed faster. Table 13 shows the results obtained from experiments 11,12 and 15 for $\mathrm{Zn}^{2+}$ and $\mathrm{Ni}^{2+}$ binary mixture. The service time decreased by about $73 \%$ and $81 \%$ with increases in flow rate for $\mathrm{Zn}^{2+}$ and $\mathrm{Ni}^{2+}$, respectively. The reduction in the zinc and nickel service time at higher flow rates is due to the unavailability of sufficient retention time for solute to interact with the sorptive sites of the biomass. On the other hand, the metal uptake per unit mass of wheat straw increased with increasing flow rate. The increase in the zinc and nickel metal uptake at higher flow rates is due to increase in the rate of mass transfer of the solute adsorbed onto unit bed depth. 
A similar trend was also observed by other researchers. Han et al. (2006b) used chaff to adsorb $\mathrm{Cu}^{2+}$ and $\mathrm{Pd}^{2+}$ in a fixed-bed column. The authors reported that as the flow rate was increased from 3.6 to $8.3 \mathrm{ml} \cdot \mathrm{min}^{-1}$, the service time declined. Similarly, Kumar and Bandyopadhyay (2006) reported an increase in metal uptake with increase in the flow rate.

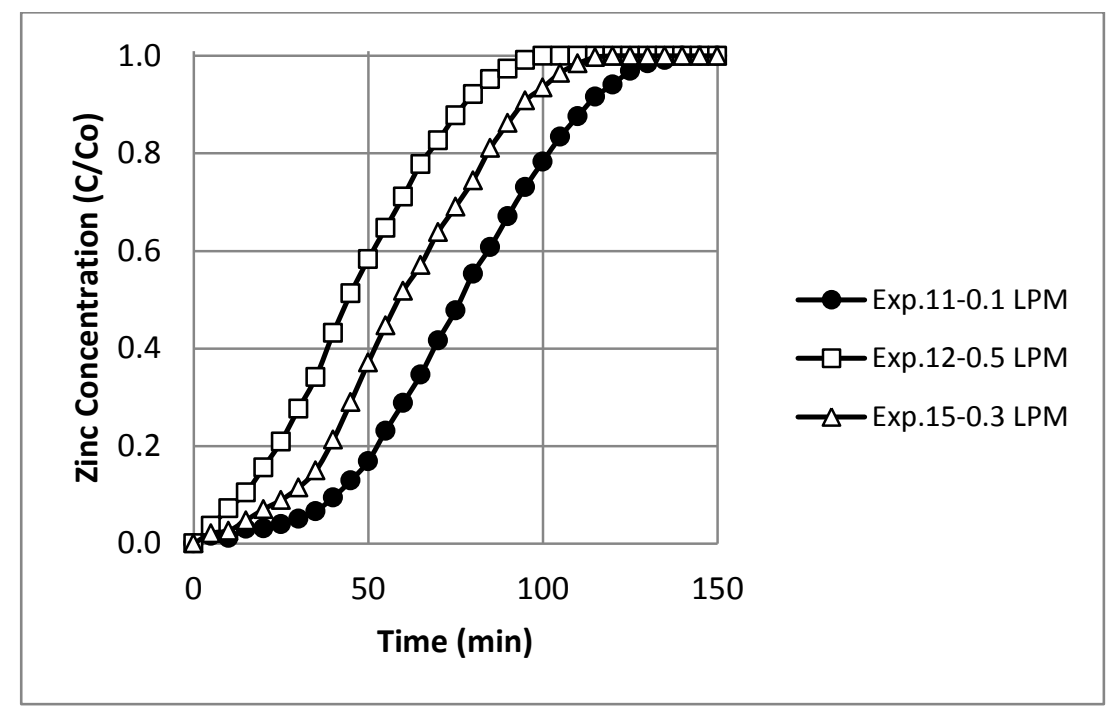

Figure 7: Effect of liquid flow rate on adsorption of $\mathrm{Zn}^{2+}$ in binary solution at bed depth $=1.25$ $\mathrm{L} / \mathrm{min}$; initial concentration $\left[\mathrm{Zn}^{2+}\right]_{0}=\left[\mathrm{Ni}^{2+}\right]_{0}=30 \mathrm{ppm}$

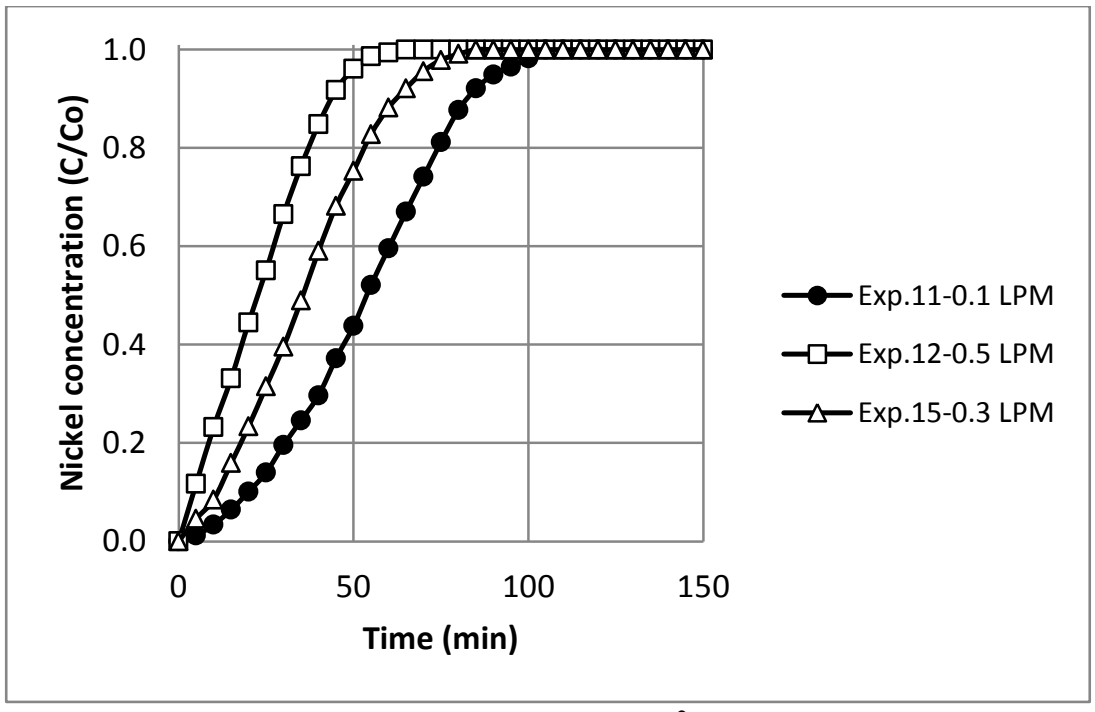

Figure 8: Effect of liquid flow rate on adsorption of $\mathrm{Ni}^{2+}$ in binary solution at bed depth $=1.25$ $\mathrm{L} / \mathrm{min}$; initial concentration $\left[\mathrm{Zn}^{2+}\right]_{0}=\left[\mathrm{Ni}^{2+}\right]_{0}=30 \mathrm{ppm}$ 
Table 13: $\mathrm{Zn}^{2+}$ and $\mathrm{Ni}^{2+}$ biosorption performances at varied inlet flow rate

\begin{tabular}{|c|c|c|c|c|c|c|c|c|}
\hline \multicolumn{2}{|c|}{ Experimental conditions } & \multicolumn{3}{c|}{$\mathbf{Z n}^{2+}$} & \multicolumn{3}{c|}{$\mathbf{N i}^{2+}$} \\
\hline $\begin{array}{c}\text { Bed } \\
\text { depth } \\
(\mathrm{m})\end{array}$ & $\begin{array}{c}\text { Liquid } \\
\text { flow rate } \\
\left(\mathrm{L}_{\left.\mathrm{min}^{-1}\right)}\right)\end{array}$ & $\begin{array}{c}\text { Initial } \\
\text { concentration } \\
\left(\mathrm{mg}_{\mathrm{L}} \mathrm{L}^{-1}\right)\end{array}$ & $\begin{array}{c}\text { Service } \\
\text { time } \\
(\mathrm{min})\end{array}$ & $\begin{array}{c}\text { Removal } \\
\text { percentage } \\
(\%)\end{array}$ & $\begin{array}{c}\text { Metal } \\
\text { uptake } \\
\left(\mathrm{mg}^{3} \mathrm{~g}^{-1}\right)\end{array}$ & $\begin{array}{c}\text { Service } \\
\text { time } \\
(\mathrm{min})\end{array}$ & $\begin{array}{c}\text { Removal } \\
\text { percentage } \\
(\%)\end{array}$ & $\begin{array}{c}\text { Metal } \\
\text { uptake } \\
\left(\mathrm{mg}_{\mathrm{g}} \mathrm{g}^{-1}\right)\end{array}$ \\
\hline 1.25 & 0.1 & 30 & 35.0 & 54.4 & 1.4 & 15.4 & 50.3 & 0.9 \\
\hline 1.25 & 0.3 & 30 & 18.2 & 49.8 & 3.4 & 7.5 & 42.3 & 1.9 \\
\hline 1.25 & 0.5 & 30 & 9.3 & 45.5 & 4.2 & 2.8 & 36.1 & 2.2 \\
\hline
\end{tabular}

Service time: The length of time to reach a specific effluent concentration; $\mathrm{C}_{\mathrm{b}}=2 \mathrm{mg} / \mathrm{L} \mathrm{Zn}^{2+}$ or Ni${ }^{2+}$

2 The time step for $\%$ removal $=\mathrm{t}_{\mathrm{s}}(\mathrm{min})$

3 The time step for metal uptake $=t_{s}(\min )$

\subsubsection{Effect of inlet concentration}

The initial concentration also plays an important role in biosorption of $\mathrm{Zn}^{2+}$ and $\mathrm{Ni}^{2+}$ binary solutions. Similar to the volumetric flow rate, the inlet metal concentration had a negative effect on the service time for both $\mathrm{Zn}^{2+}$ and $\mathrm{Ni}^{2+}$. The breakthrough data for different initial concentrations of $\mathrm{Zn}^{2+}$ and $\mathrm{Ni}^{2+}$ at fixed flow rate of $0.3 \mathrm{~L} / \mathrm{min}$ and bed depth of $1.25 \mathrm{~m}$ are presented in Figures 9 and 10, respectively, according experiments numbers 13 to 15 . At the lowest influent concentration $\left(\mathrm{C}_{\mathrm{o}}=10 \mathrm{mg}-\mathrm{Zn}-\mathrm{Ni} / \mathrm{L}\right)$, the most dispersive breakthrough curve were displayed, whereas the slopes of the curve at the highest concentration $(50 \mathrm{mg}-\mathrm{Zn}-\mathrm{Ni} / \mathrm{L})$ were the steepest. Similar trends were also reported in the column studies using immobilized $C$. vulgaris (Aksu, 1998) and immobilized Pseudomonas aeruginosa (Texier et al., 2002).

Seen in Table 14, as the inlet concentration was increased from 10 to $50 \mathrm{mg} \cdot \mathrm{L}^{-1}$, the service time decreased from 47.6 to $6.3 \mathrm{~min}$ and 24.7 to $2.1 \mathrm{~min}$ for $\mathrm{Zn}^{2+}$ and $\mathrm{Ni}^{2+}$, respectively. This is mainly due to the number of available binding sites relative to the metal ion concentration. At a low metal concentration, more binding sites are available for adsorption of ions; hence, more metal ions were adsorbed resulting in a lower metal concentration at the outlet and a longer service time. On the other hand, at a higher concentration, the number of ions competing for the 
available binding sites would be higher. The biosorbent would get saturated faster; hence, the service time becomes shorter. Furthermore, the results also indicated that initial concentration has a strong positive effect on adsorption uptake capacity. This is due to fact that initial concentration provides the driving force to overcome all mass transfer resistances of the metal ions transport between the solution and the surface of the biomass. Hence, a high initial concentration provides a high driving force for the adsorption process.

Zulfadhly et al. (2001) examined the effect of the initial concentration of lead, copper and cadmium on their adsorption in a fixed-bed of the macro fungus Pycnoporus sanguineus and found that the service time decreased with increase in initial concentrations. Likewise, Blázquez et al. (2010) observed an increase in the service time and decrease in metal uptake as the inlet chromium concentration was reduced from 100 to $10 \mathrm{mg} . \mathrm{L}^{-1}$.

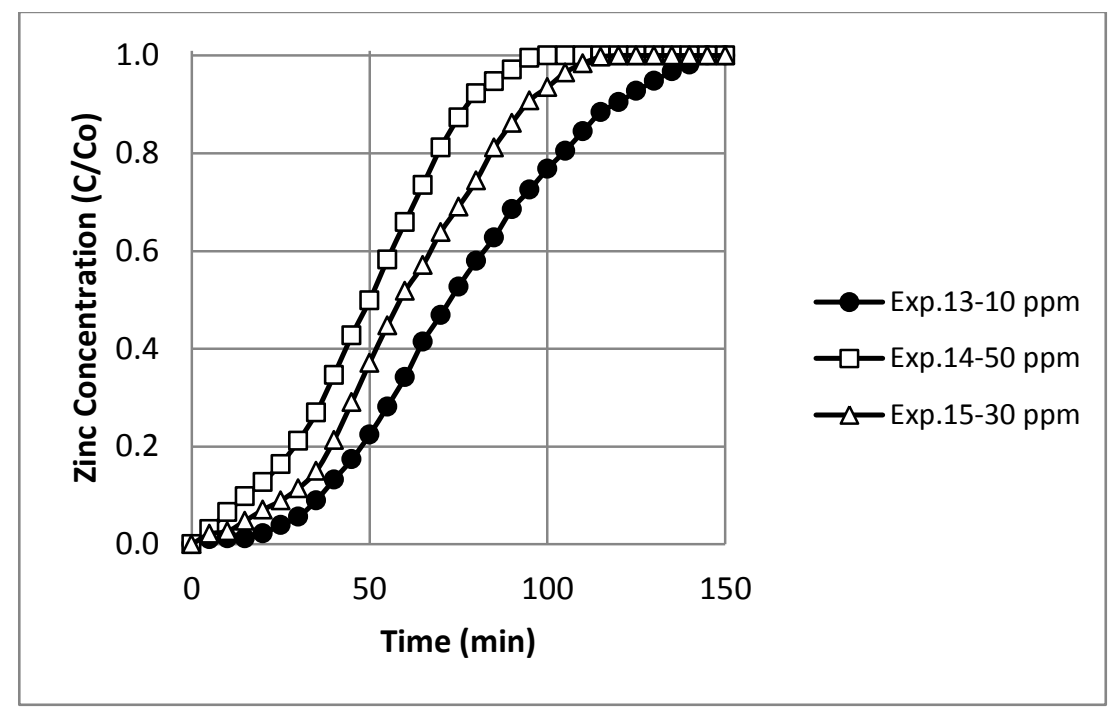

Figure 9: Effect of the inlet concentration on adsorption of $\mathrm{Zn}^{2+}$ in binary solution at bed depth = $1.25 \mathrm{~L} / \mathrm{min}$; volumetric flow rate $=0.3 \mathrm{~L} / \mathrm{min}$ 


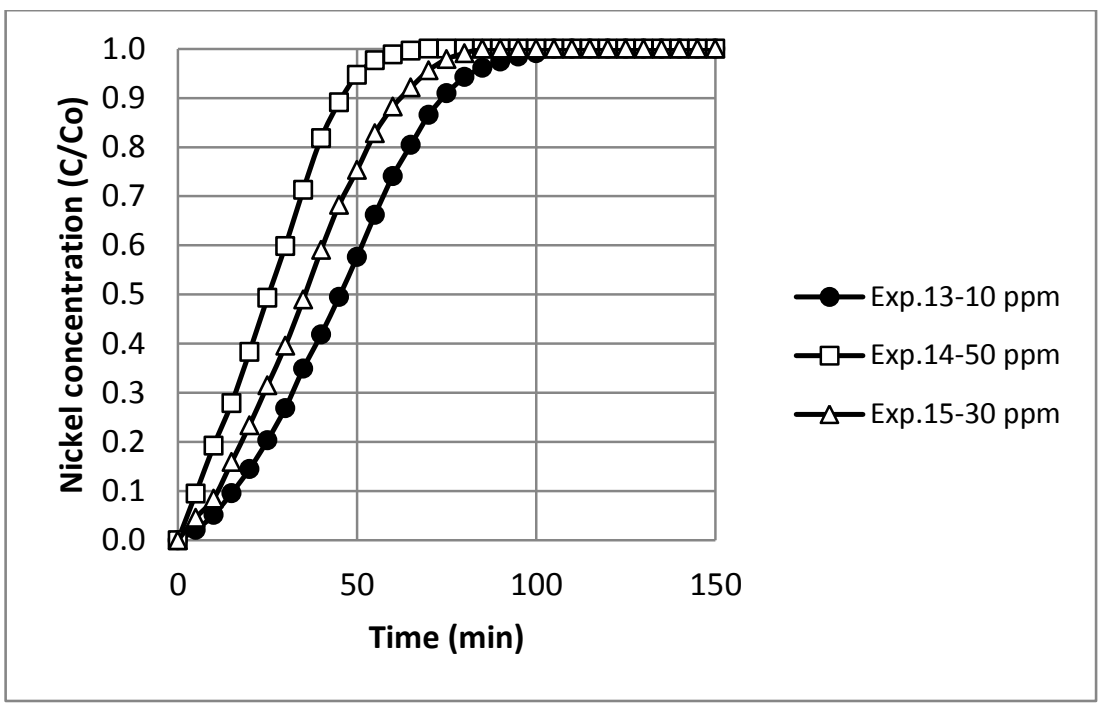

Figure 10: Effect of the inlet concentration on adsorption of $\mathrm{Ni}^{2+}$ in binary solution at bed depth = $1.25 \mathrm{~L} / \mathrm{min}$; volumetric flow rate $=0.3 \mathrm{~L} / \mathrm{min}$

Table 14: $\mathrm{Zn}^{2+}$ and $\mathrm{Ni}^{2+}$ biosorption performances at varied initial concentration

\begin{tabular}{|c|c|c|c|c|c|c|c|c|}
\hline \multicolumn{3}{|c|}{ Experimental conditions } & \multicolumn{3}{|c|}{$\mathrm{Zn}^{2+}$} & \multicolumn{3}{|c|}{$\mathrm{Ni}^{2+}$} \\
\hline $\begin{array}{c}\text { Bed } \\
\text { depth } \\
(\mathrm{m})\end{array}$ & $\begin{array}{l}\text { Liquid } \\
\text { flow rate } \\
\left(\text { L.min }^{-1}\right)\end{array}$ & $\begin{array}{c}\text { Initial } \\
\text { concentration } \\
\left(\mathrm{mg} . \mathrm{L}^{-1}\right)\end{array}$ & $\begin{array}{l}\text { Service } \\
\text { time } \\
(\min )^{1}\end{array}$ & $\begin{array}{c}\text { Removal } \\
\text { percentage } \\
(\%)^{2}\end{array}$ & $\begin{array}{c}\text { Metal } \\
\text { uptake } \\
\left(\mathrm{mg} \cdot \mathrm{g}^{-1}\right)^{3}\end{array}$ & $\begin{array}{l}\text { Service } \\
\text { time } \\
(\mathrm{min})\end{array}$ & $\begin{array}{c}\text { Removal } \\
\text { percentage } \\
(\%)\end{array}$ & $\begin{array}{c}\text { Metal } \\
\text { uptake } \\
\left(\mathrm{mg}^{\left.-g^{-1}\right)}\right.\end{array}$ \\
\hline 1.25 & 0.3 & 10 & 47.6 & 51.9 & 1.4 & 19.5 & 43.06 & 0.83 \\
\hline 1.25 & 0.3 & 30 & 18.2 & 49.8 & 3.4 & 7.5 & 42.31 & 1.99 \\
\hline 1.25 & 0.3 & 50 & 6.3 & 48.8 & 4.5 & 2.1 & 36.65 & 2.37 \\
\hline
\end{tabular}

Service time: The length of time to reach a specific effluent concentration; $\mathrm{C}_{\mathrm{b}}=2 \mathrm{mg} / \mathrm{L} \mathrm{Zn}^{2+}$ or Ni${ }^{2+}$

${ }^{2}$ The time step for $\%$ removal $=\mathrm{t}_{\mathrm{s}}(\mathrm{min})$

${ }^{3}$ The time step for metal uptake $=t_{s}(\min )$

\subsection{Best conditions of $\mathrm{Zn}^{2+}$ and $\mathrm{Ni}^{2+}$ binary biosorption system}

The results showed that breakthrough service time of the biosorption columns $\left(\mathrm{C}_{\mathrm{b}}=2 \mathrm{mg}-\mathrm{Zn}\right.$ $\mathrm{Ni} / \mathrm{L}$ ) increased with increasing bed depth, while decreased with increasing influent concentrations and flow rates, as expected. The maximum experimental service time for $\mathrm{Zn}^{2+}$ and $\mathrm{Ni}^{2+}$ were $87 \mathrm{~min}$ and $67 \mathrm{~min}$ at the bed depth of $2 \mathrm{~m}$, liquid flow rate of $0.1 \mathrm{~L} \cdot \mathrm{min}^{-1}$, initial concentration of $10 \mathrm{mg} . \mathrm{L}^{-1}$ and biomass particle size of $0.5 \mathrm{inch}$. Thus, the best performance in biosorption of $\mathrm{Zn}^{2+}$ and $\mathrm{Ni}^{2+}$ binary solutions was at smallest biosorbent particle size ( $\left.0.5 \mathrm{inch}\right)$, highest bed depth $(2 \mathrm{~m})$, lowest flow rate $\left(0.1 \mathrm{~L} \cdot \mathrm{min}^{-1}\right)$ and smallest initial concentration (10 $\mathrm{mg} / \mathrm{L}$ ), at which the outlet concentration of both metal ions were $\leq 2.0 \mathrm{ppm}$ for about $67 \mathrm{~min}$. In 
order to maintain the concentration of $\mathrm{Zn}^{2+}$ and $\mathrm{Ni}^{2+} \leq 2 \mathrm{mg} \cdot \mathrm{L}^{-1}$ at the biosorber outlet, the biosorbent needed to be regenerated every $67 \mathrm{~min}$.

\subsection{Bed Depth Service Time (BDST) model}

The BDST model correlates the bed depth and the service time. Figures 11A and 11B show the plots of the service time against the bed depth at different flow rates for $\mathrm{Zn}^{2+}$ and $\mathrm{Ni}^{2+}$ binary mixture at a fixed inlet concentration of $10 \mathrm{mg} \cdot \mathrm{L}^{-1}$. The correlation coefficients $\left(\mathrm{R}^{2}\right)$ as well as the model constants $\mathrm{k}$ and $\mathrm{N}_{\mathrm{o}}$, were estimated according to Equation (2-1), shown in Table 15. The values of correlation coefficient $\left(\mathrm{R}^{2}\right)$ are close to 1 indicating a good fit of the BDST model to experimental data. Hence, the model can be used to predict the service time of a large-scale bioadsorber. The BDST model parameter, $\mathrm{k}$, increased with change in flow rate. This could be the consequence of increased mass transfer of solute in the liquid phase to the solid phase as liquid flow rate increased. Likewise, the results indicated increase in adsorption capacity $\left(\mathrm{N}_{\mathrm{o}}\right)$ with increasing flow rate.

Table 15: The BDST model parameters obtained from fitting of breakthrough data to the model at fixed binary initial concentration $\left[\mathrm{Zn}^{2+}\right]_{0}=\left[\mathrm{Ni}^{2+}\right]_{0}=10 \mathrm{ppm}$

\begin{tabular}{|c|c|c|c|c|c|c|}
\hline & \multicolumn{3}{|c|}{$\mathrm{Zn}^{2+}$} & \multicolumn{3}{c|}{$\mathrm{Ni}^{2+}$} \\
\hline $\begin{array}{c}\text { Flow rate } \\
(\mathbf{L} / \mathbf{m i n})\end{array}$ & $\begin{array}{c}\mathbf{k} \\
\text { L/mg.min) }\end{array}$ & $\begin{array}{c}\mathbf{N}_{\mathbf{o}} \\
(\mathbf{m g} / \mathbf{L})\end{array}$ & $\mathbf{R}^{\mathbf{2}}$ & $\begin{array}{c}\mathbf{k} \\
\text { L/mg.min })\end{array}$ & $\begin{array}{c}\mathbf{N}_{\mathbf{o}} \\
(\mathbf{m g} / \mathbf{L})\end{array}$ & $\mathbf{R}^{\mathbf{2}}$ \\
\hline 0.1 & 0.0372 & 22.8 & 0.99 & 0.0294 & 17.6 & 0.99 \\
\hline 0.3 & 0.0629 & 26.2 & 0.99 & 0.0542 & 21.7 & 0.99 \\
\hline 0.5 & 0.0976 & 31.6 & 0.99 & 0.0828 & 26.1 & 0.99 \\
\hline
\end{tabular}

Ghasemi et al. (2011) used the BDST model to correlate the data obtained for biosorption of Uranium (VI) from aqueous solutions by Ca-pretreated Cystoseira indica alga. Likewise, the 
applicability of the BDST model was shown in biosorption of lead using immobilized Aeromonas hydrophila biomass (Hasan et al., 2010).

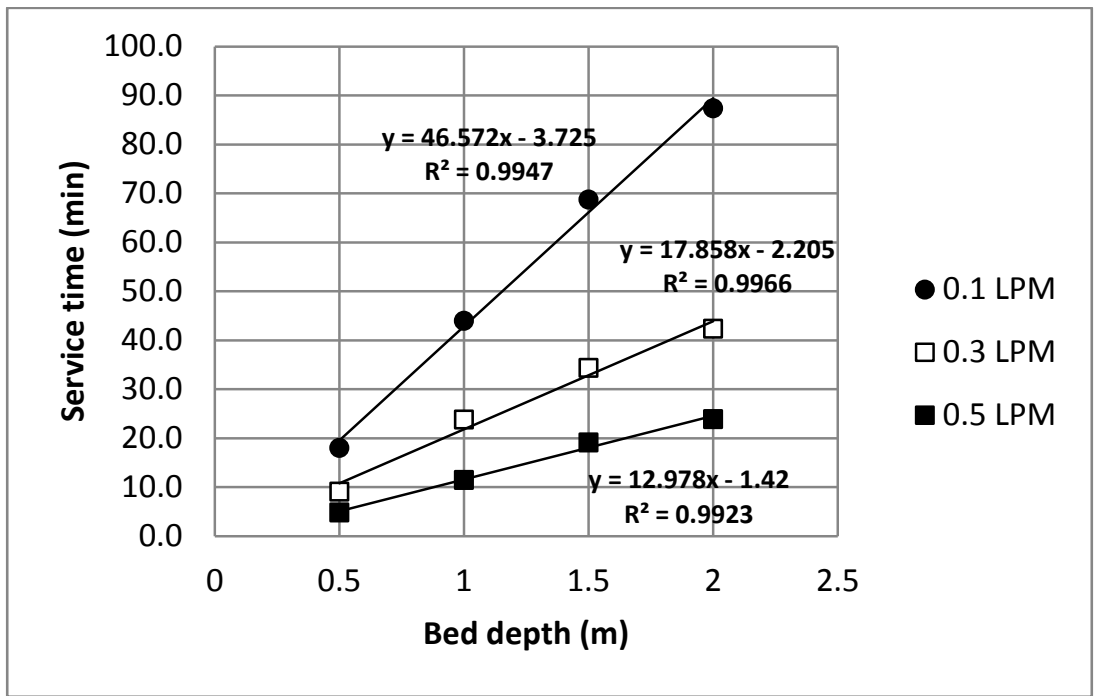

A)

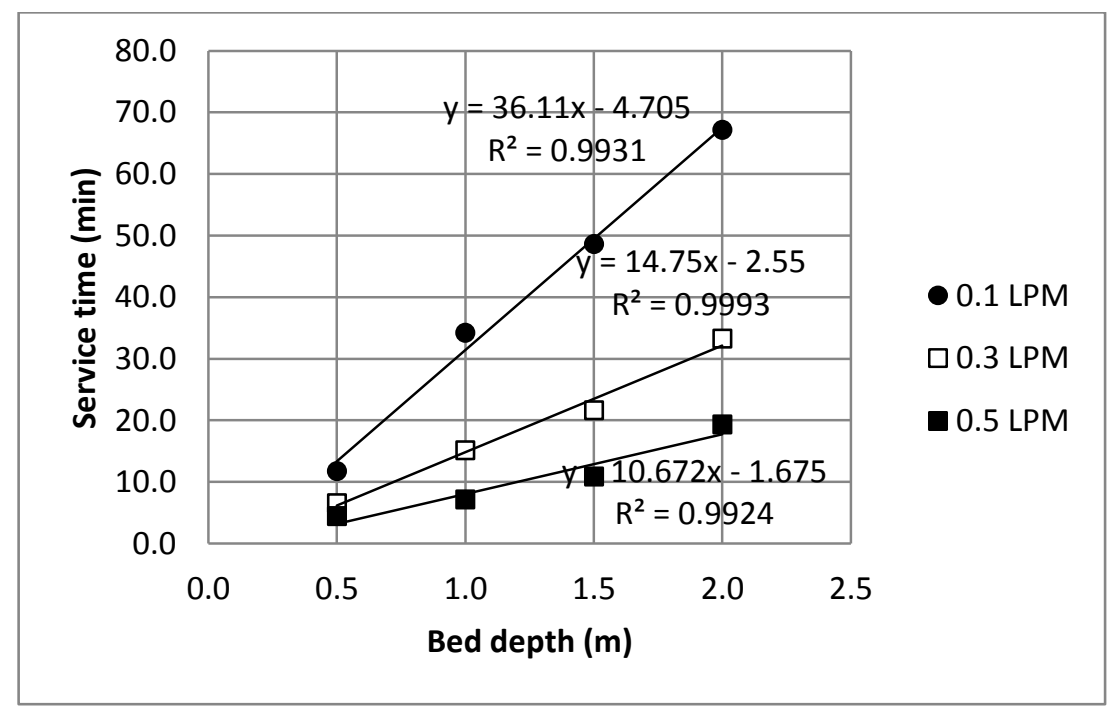

B)

Figure 11: BDST model for (A) $\mathrm{Zn}^{2+}$ and (B) $\mathrm{Ni}^{2+}$ at different flow rates for at given binary initial concentration $\left[\mathrm{Zn}^{2+}\right]_{0}=\left[\mathrm{Ni}^{2+}\right]_{0}=10 \mathrm{ppm}$

*For better evaluation the BDST model extra experiments were conducted at varied bed depths of 1 and $1.5 \mathrm{~m}$ 


\subsection{Competitive biosorption of $\mathrm{Zn}^{2+}$ and $\mathrm{Ni}^{2+}$ onto wheat straw}

Although, real wastewater contains more than one type of heavy metals, more attention has been paid to the biosorption of single-ion systems. In multi-component systems, the sorption of heavy metal ions depends not only on the specific surface properties of the biomass and on the physicochemical parameters of the solution, i.e., temperature, $\mathrm{pH}$ and initial metal-ion concentration, but also on features of those components, as well as the number of different metal ions competing for binding sites and ratio of metal concentration (Li et al., 2004). The objective of this part of study is to investigate the competition of $\mathrm{Zn}^{2+}$ and $\mathrm{Ni}^{2+}$ binary mixture at varied ratios. As well as, examine the performance of fixed-bed biosorption at best operation conditions under single-ion (Zinc and Nickel) systems.

\subsubsection{Effect of competitive ions on the sorption}

Figure 12 shows the metal uptake of $\mathrm{Zn}^{2+}$ and $\mathrm{Ni}^{2+}$ binary mixture at the given bed depth of $2 \mathrm{~m}$ and volumetric flow rate of $0.1 \mathrm{~L} / \mathrm{min}$ and varied ratio metal concentration $\left(\mathrm{C}_{\mathrm{o}-\text { Zind }} / \mathrm{C}_{\mathrm{o} \text {-Nickel }}\right)$ of $0.25,0.5,1,1.5$ and 2 . According to Figure 12 , at equally initial $\mathrm{Zn}^{2+}$ and $\mathrm{Ni}^{2+}$ concentrations $\left(\mathrm{C}_{\mathrm{o}}\right.$ Zind $/ \mathrm{C}_{\text {o-Nickel }}=10 \mathrm{ppm} / 10 \mathrm{ppm}=1$ ), the uptake capacity of zinc was higher than nickel.

Among various factors that affect the sorption preferences of a sorbent, binding of metal ions on material depends on physic-chemical properties of the metals (i.e. atomic weight and electronegativity), as well as the solubility of the solute. It has been reported that the affinity of sorption between the sites and the metal ion increases with the greater the atomic weight and electronegativity of the heavy metal, while decreases with its solubility. The explanation of each factor is shown below: 
- Atomic weight: The movement of metals with a higher atomic weight can generate higher momentum energy, which may promote the biosorption of the metal by increasing the probability of effective collision between the metal and the biosorbent surface. Hence, a higher atomic weight leads to a higher biosorption preference by the biosorbent (Hassle, 1974; Sağ et al., 2002).

- Electro-negativity: A general rule in heavy metal biosorption is that the higher charged the ions, the higher the affinity. In other words, more electronegative metal ions will be more strongly attracted to the surface (Kotrba et al., 2011).

- Solubility: The more soluble compound generally adsorbed less than the insoluble compound because the more soluble compound has stronger affinity with the solvent than does the less soluble one (Benefield et al., 1982).

According to results obtained, the selectivity order for metal ions towards wheat straw is:

$$
\mathrm{Zn}^{2+}>\mathrm{Ni}^{2+}
$$

This might due to the fact that 1) zinc has a higher atomic weight (atomic weight $=65.38 \mathrm{Da}$ ) than nickel (58.69 Da) and 2) $\mathrm{Zn}^{2+}$ has a lower aqueous solubility than $\mathrm{Ni}^{2+}$ (Fraile et al., 2005). It is important to note that even though the electro-negativity of $\mathrm{Zn}^{2+}(1.65 \chi)$ is lower than $\mathrm{Ni}^{2+}$

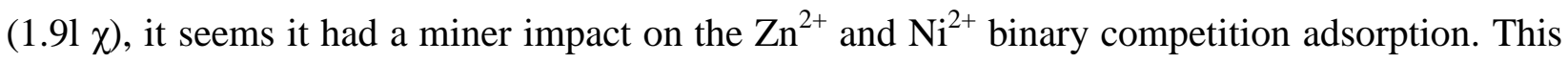
order was also observed by Sheng et al. (2004), Saeed et al. (2005b) and Hanif et al. (2007).

Furthermore, even though zinc has a higher affinity toward wheat straw than nickel, as initial concentration of zinc was doubled from a ratio of $1\left(\mathrm{C}_{\mathrm{o}-\text { Zind }} / \mathrm{C}_{\mathrm{o}-\mathrm{Nickel}}=10 / 10\right)$ to a ratio of $2\left(\mathrm{C}_{\mathrm{o}}\right.$ Zind $/ \mathrm{C}_{\text {o-Nickel }}=20 / 10$ ), the uptake capacity only increased slightly about $5 \%$ in bed depth of $2 \mathrm{~m}$ 
(Figure 12). This might be due to fact that there was an abundance of sorbing sits on biomass surface in the tall bed of $2 \mathrm{~m}$ high while the concentration of $\mathrm{Zn}^{2+}$ and $\mathrm{Ni}^{2+}$ in the influent to the adsorber was low.

For the observation of the competition adsorption of a binary mixture of $\mathrm{Zn}^{2+}$ and $\mathrm{Ni}^{2+}$, further experiments were conducted with the reduction of bed depth from 2 to $0.5 \mathrm{~m}$, volumetric flow rate of $0.1 \mathrm{~L} / \mathrm{min}$ and increasing the influent concentration based on varied $\mathrm{C}_{\mathrm{o}-\mathrm{Zinc}} / \mathrm{C}_{\mathrm{o}-\mathrm{Nickel}}$ concentration ratios $(0.25,0.5,1,1.5$ and 2$)$ with $\mathrm{C}_{\mathrm{o}}[\mathrm{Ni}]=100 \mathrm{mg} / \mathrm{L}$ (Figures 12 and 13). The results indicated that $\mathrm{Zn}^{2+}$ uptake increased by more than $80 \%$ as the concentration ratio was increased, while the uptake of $\mathrm{Ni}^{2+}$ decreased by $50 \%$ (Figure 13). The breakpoint ratio is at 0.65 , beyond which the preferred metal ions; $\mathrm{Zn}^{2+}$ in this case, would displace the less preferable species from the biosorbent. This would lead the two different metal species would compete with each other for the limiting amount of binding sites available in the short bed. It is important to note that despite the fact the bed depth was reduced from $2 \mathrm{~m}$ to $0.5 \mathrm{~m}$, in Figure 12, at given $\mathrm{C}_{\mathrm{o}}[\mathrm{Ni}]=10 \mathrm{mg} / \mathrm{L}$ the competition of $\mathrm{Zn}^{2+}$ and $\mathrm{Ni}^{2+}$ in adsorbtion is not obvious. This indicated that the influent concentrations of $\mathrm{Zn}^{2+}$ and $\mathrm{Ni}^{2+}$ overlook the competitive adsorption in this part of study. It is relevant to note that the maximum metal uptakes of both $\mathrm{Zn}^{2+}$ and $\mathrm{Ni}^{2+}$ remained relatively constant for all concentration ratios used in the experiments. 


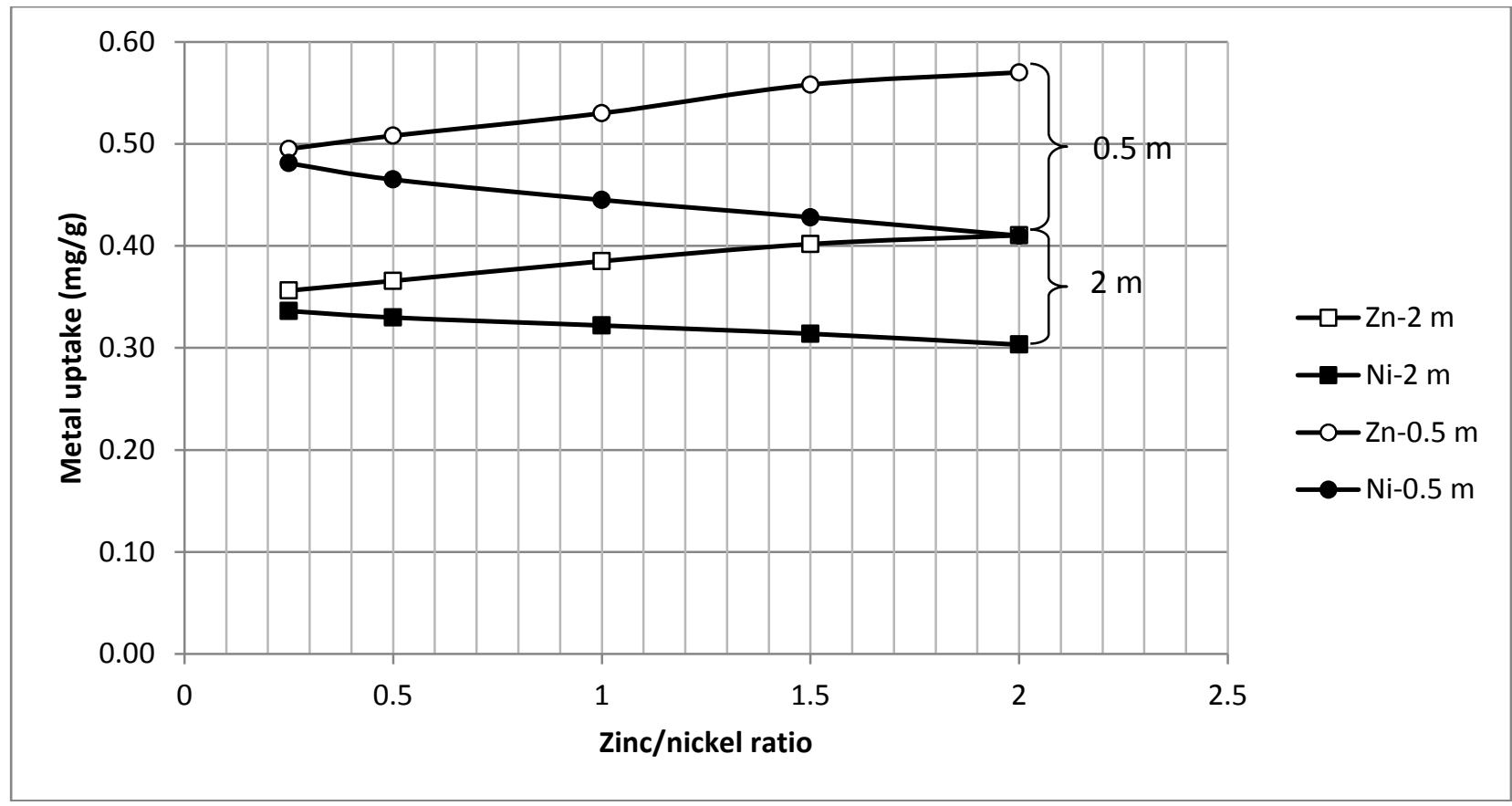

Figure 12: Comparison of metal uptakes of $\mathrm{Zn}^{2+}$ and $\mathrm{Ni}^{2+}$ in binary-metal systems at different $\mathrm{Co}[\mathrm{Zn}]$ for a given $\mathrm{Co}[\mathrm{Ni}]=10 \mathrm{mg} / \mathrm{L}$; volumetric flow rate of $0.1 \mathrm{~L} / \mathrm{min}$; and bed depths of 2 and 0.5 m.

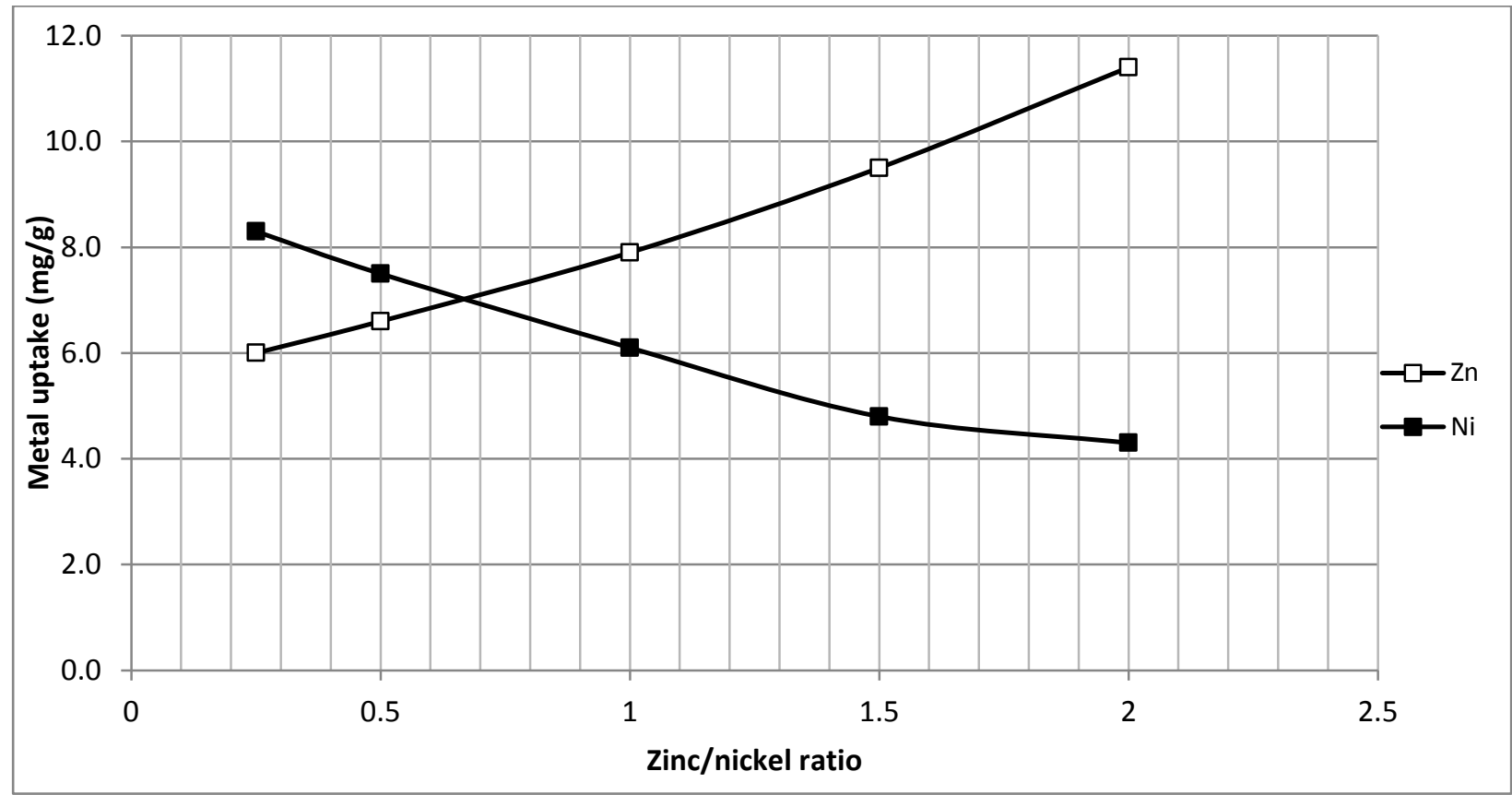

Figure 13: Comparison of metal uptakes of $\mathrm{Zn}^{2+}$ and $\mathrm{Ni}^{2+}$ in binary-metal systems at different $\mathrm{Co}[\mathrm{Zn}]$ for a given $\mathrm{Co}[\mathrm{Ni}]=100 \mathrm{mg} / \mathrm{L}$; volumetric flow rate of $0.1 \mathrm{~L} / \mathrm{min}$ and bed depth of $0.5 \mathrm{~m}$. 


\subsubsection{Biosorption of single component heavy metal solution}

The fixed-bed biosorption in the single component were also investigated. Similar to Section 3.2, experiments were carried out by introducing the single-metal influent solutions into the fixed-bed columns with $2 \mathrm{~m}$ bed depth at $0.1 \mathrm{~L} / \mathrm{min}$ inlet upward flow rate. Zinc sulphate and Nickel sulphate were used to prepare $\mathrm{Zn}^{2+}$ and $\mathrm{Ni}^{2+}$ single-metal influent solutions at $\mathrm{pH}$ 7.0. The concentration of each metal species was fixed at $10 \mathrm{mg} / \mathrm{L}$. The breakthrough curves of the $\mathrm{Zn}^{2+}$ and $\mathrm{Ni}^{2+}$ in binary and single ions systems at bed depth of $2 \mathrm{~m}$, volumetric flow rate of $0.1 \mathrm{~L} / \mathrm{min}$ and initial concentration of $10 \mathrm{mg} / \mathrm{L}$ are presented in Figures 14 and 15, respectively.

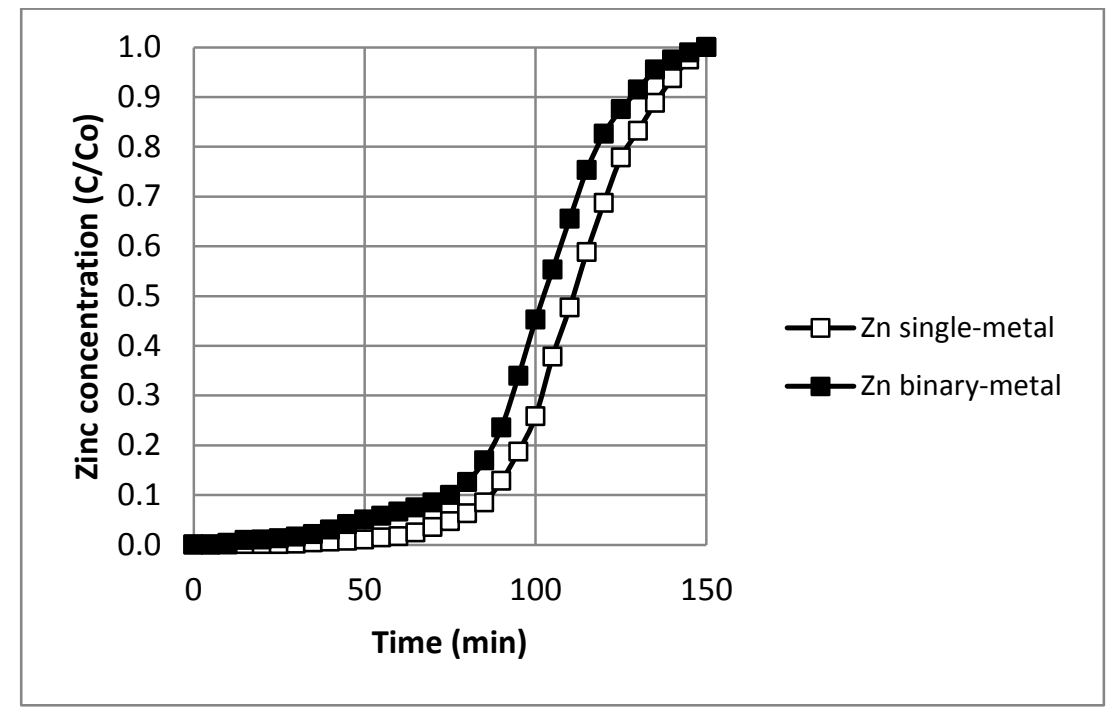

Figure 14: Comparison breakthrough curves of biosorption of $\mathrm{Zn}^{2+}$ in single-metals and binary solutions 


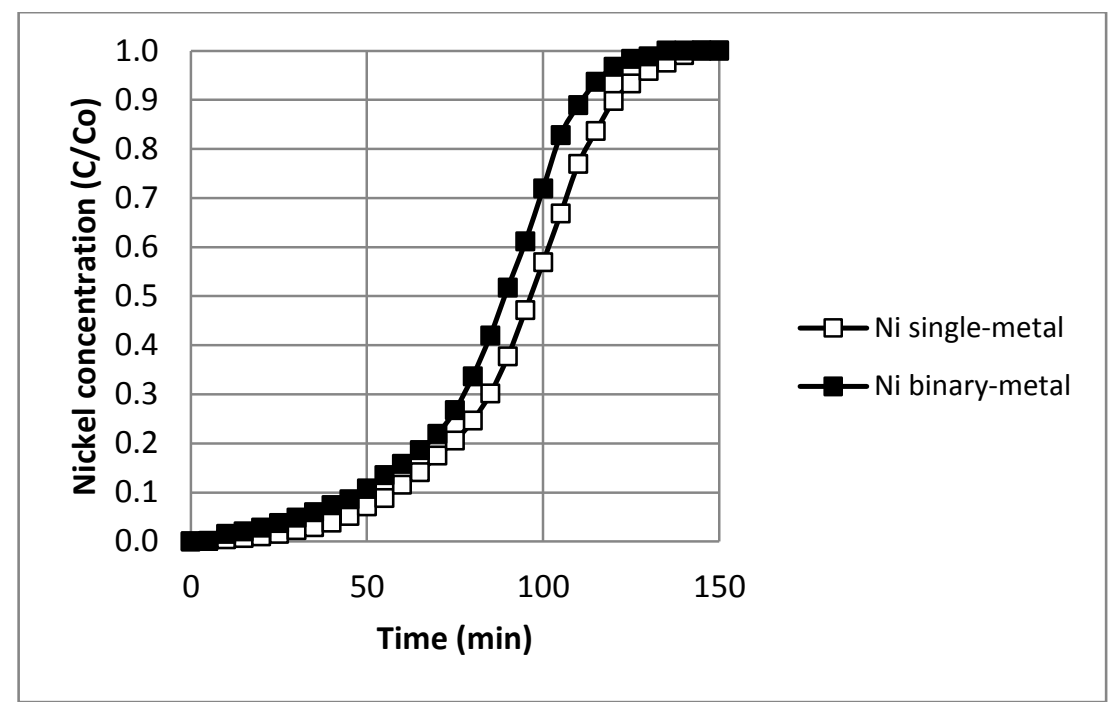

Figure 15: Comparison breakthrough curves of biosorption of $\mathrm{Ni}^{2+}$ in single-metals and binary solutions

These two figures illustrate that service times increased for both heavy metals in single-metal solutions compared with the binary-metal systems. This was due to less competition for the binding sites for the target metal ions. Table 16 summarizes the adsorption capacity, percentage removal and service time in single and binary systems. The results indicated that adsorption capacity and removal percentage for the binary mixture was lower than that for the single component system. For instance, in case where $\mathrm{Zn}$ was set as a primary component, the adsorption capacity increased by about $9 \%$ by changing the systems from binary to single component.

Kaewsarn (2000) investigated the effect of other heavy metal ions on $\mathrm{Cu}^{2+}$ uptake by Durvilaea potatorum. The author reported that $\mathrm{Cu}^{2+}$ uptake was significantly affected by other heavy metals $\left(\mathrm{Ag}^{+}, \mathrm{Mn}^{2+}, \mathrm{Co}^{2+}, \mathrm{Ni}^{2+}, \mathrm{Zn}^{2+}, \mathrm{Fe}^{2+}, \mathrm{Cd}^{2+}, \mathrm{Pb}^{2+}\right)$. Similarly, Sengil and Özacar (2009) studied the competitive biosorption of $\mathrm{Pb}^{2+}, \mathrm{Cu}^{2+}$ and $\mathrm{Zn}^{2+}$ on valonia tannin resin (VTR) in multi-metals combination and compared with single metal solution. The experimental results indicated that the 
uptake capacity and percentage removal of one metal ion were reduced by the presence of the other metal ion.

Table 16: Comparison uptake capacity, percentage removal and service time of $\mathrm{Zn}^{2+}$ and $\mathrm{Ni}^{2+}$ ions in single and binary-metal systems

\begin{tabular}{|c|c|c|c|c|c|c|}
\hline \multirow{2}{*}{$\begin{array}{c}\text { Metal } \\
\text { ion }\end{array}$} & \multicolumn{3}{|c|}{ Single-metal systems } & \multicolumn{3}{c|}{ Binary-metal systems } \\
\cline { 2 - 7 } & $\begin{array}{c}\text { Service } \\
\text { time } \\
(\mathrm{min})\end{array}$ & $\begin{array}{c}\text { Removal } \\
\text { percentage } \\
(\%)\end{array}$ & $\begin{array}{c}\text { Uptake } \\
\text { capacity } \\
(\mathrm{mg} / \mathrm{g})\end{array}$ & $\begin{array}{c}\text { Service } \\
\text { time } \\
(\mathrm{min})\end{array}$ & $\begin{array}{c}\text { Removal } \\
\text { percentage } \\
(\%)\end{array}$ & $\begin{array}{c}\text { Uptake } \\
\text { capacity } \\
(\mathrm{mg} / \mathrm{g})\end{array}$ \\
\hline $\mathrm{Zn}$ (II) & 94 & 72.5 & 0.414 & 87 & 66.7 & 0.385 \\
\hline $\mathrm{Ni}$ (II) & 73 & 67.6 & 0.351 & 67 & 62.2 & 0.324 \\
\hline
\end{tabular}




\section{6 $\mathrm{Zn}^{2+}$ and $\mathrm{Ni}^{2+}$ binary desorption studies}

The development of metal biosorbents should not concentrate only on evaluating their biosorption characteristics. Regeneration and reuse of the biosorbent should be considered too. Before the desorption step was carried out, the biosorption step was done with $2 \mathrm{~m}$ bed depth, 10

$\mathrm{mg} / \mathrm{L}$ equally $\mathrm{Zn}^{2+}$ and $\mathrm{Ni}^{2+}$ binary influent concentrations, a $0.1 \mathrm{~L} / \mathrm{min}$ inlet upward flow rate and 0.5 inch particle size.

In this part of the present study, experiments were carried out to examine the effectiveness of the type, concentration and flow rate of the desorbing agent for desorption process. These studies were carried out in the fixed-bed system.

\subsubsection{Effect of the type of desorbing agent and concentration}

Among different desorbing agents, mineral acids like hydrochloric acid, nitric acid and sulphuric acid have been proven to be more effective than other elute chemicals (Stirk and Staden, 2002; Kuczajowska-Zadrożna et al., 2004). This part of the present study investigated the effect of hydrochloric acid, nitric acid and sulphuric acid as desorbing agents on wheat straw regeneration process at varied concentrations from 0.1 to $0.5 \mathrm{M}$ at given flow rate of $0.1 \mathrm{~L} / \mathrm{min}$. Table 17 summarizes the effect of desorbing agents in the three biosorption/desorption cycles. The results in Table 17 show that the elution efficiency decreased significantly when the concentration was increased from 0.1 to $0.5 \mathrm{~mol} . \mathrm{L}^{-1}$. This might be due to the precipitation of metal ions with dissociated anions of the acid. For example, sulphuric acid was dissociated into sulphate anions and hydrogen ions. The metal sulphate precipitate deposited on the biosorbent, and hence, couldn't be desorbed to the solution. Figures 16 and 17 demonstrate desorption curves for $\mathrm{Zn}^{2+}$ and $\mathrm{Ni}^{2+}$ at varied acid concentration of sulfuric acid as desorbing agent. At higher acid 
concentration, the metal concentration in the desorbed solution dropped faster and sharper during $\mathrm{Zn}^{2+}$ and $\mathrm{Ni}^{2+}$ desorption process. Desorption curves for $\mathrm{Zn}^{2+}$ and $\mathrm{Ni}^{2+}$ solution at given electrolyte flow rate of $0.1 \mathrm{~L} / \mathrm{min}$ for hydrochloric acid, nitric acid are shown in Figures B-1, B-2, B-3 and B-4 (Appendix B-1).

Addour et al. (1999) used $\mathrm{HCl}$ as a desorbing agent for the regeneration of Streptomyces rimosus biosorbent laden with $\mathrm{Zn}^{2+}$. They recovered about $90 \% \mathrm{Zn}^{2+}$ at the concentration of 0.1 mol. $\mathrm{L}^{-1}$ while about $50 \%$ at a high concentration of $0.5 \mathrm{~mol} \cdot \mathrm{L}^{-1}$.

Furthermore, the effect of the type of desorbing agent on biomass regeneration was also examined and shown in Table 17. For the first cycle, hydrochloric acid gives the highest elution efficiency followed by sulfuric acid. However, as the cycles continued the elution efficiency with hydrochloric acid decreased more substantially compared to the other desorption agents. This may due to the acid strength of the desorbing agent. Hydrochloric acid has the highest acid strength $(\mathrm{pKa}=-6.3)$ followed by sulfuric acid $(\mathrm{pKa}=-3)$ and nitric acid $(\mathrm{pKa}=-1.4)($ Hill and Petrucci, 1996). Therefore, hydrochloric acid would cause more damage to sorbing sites or accessibility to the binding sites than other desorbing agents as the cycles progressed (Volesky et al., 2003). Consequently, sulfuric acid $\left(\mathrm{H}_{2} \mathrm{SO}_{4}\right)$ at $0.1 \mathrm{M}$ was chosen for the fixed-bed desorption process since it showed a better performance in zinc and nickel recovery throughout the three cycles. 
Table 17: Elution efficiency of zinc and nickel solution after three biosorption/desorption cycles using different desorbing agents at flow of $0.1 \mathrm{~L} / \mathrm{min}$

\begin{tabular}{|l|c|l|l|l|l|l|l|}
\hline & & \multicolumn{3}{|c|}{ Elution efficiency (\%)-Zinc } & \multicolumn{3}{c|}{ Elution efficiency (\%)-Nickel } \\
\hline $\begin{array}{c}\text { Desorbing } \\
\text { agent }\end{array}$ & $\begin{array}{c}\text { Acid } \\
\text { concentration } \\
(\mathbf{M})\end{array}$ & Cycle 1 & Cycle 2 & Cycle 3 & Cycle 1 & Cycle 2 & Cycle 3 \\
\hline \multirow{2}{*}{$\begin{array}{l}\text { Hydrochloric } \\
\text { acid (HCl) }\end{array}$} & 0.1 & 87.3 & 75.9 & 63.1 & 86.1 & 74.9 & 62.2 \\
\cline { 2 - 8 } & 0.3 & 73.3 & 60.1 & 46.9 & 72.2 & 59.2 & 46.2 \\
\hline \multirow{2}{*}{$\begin{array}{l}\text { Sulfuric acid } \\
\left(\mathrm{H}_{2} \mathrm{SO}_{4}\right)\end{array}$} & 0.5 & 67.4 & 53.2 & 39.4 & 66.5 & 52.5 & 38.9 \\
\cline { 2 - 8 } & 0.1 & 83.1 & 80.6 & 76.6 & 82.4 & 79.9 & 75.9 \\
\hline \multirow{2}{*}{$\begin{array}{l}\text { Nitric acid } \\
\left(\mathrm{HNO}_{3}\right)\end{array}$} & 0.3 & 69.7 & 64.8 & 58.3 & 68.2 & 63.4 & 57.1 \\
\cline { 2 - 8 } & 0.5 & 64.1 & 57.7 & 50.2 & 63.7 & 57.3 & 47.8 \\
\cline { 2 - 8 } & 0.3 & 60.9 & 78.4 & 74.5 & 79.9 & 77.4 & 73.5 \\
\hline
\end{tabular}

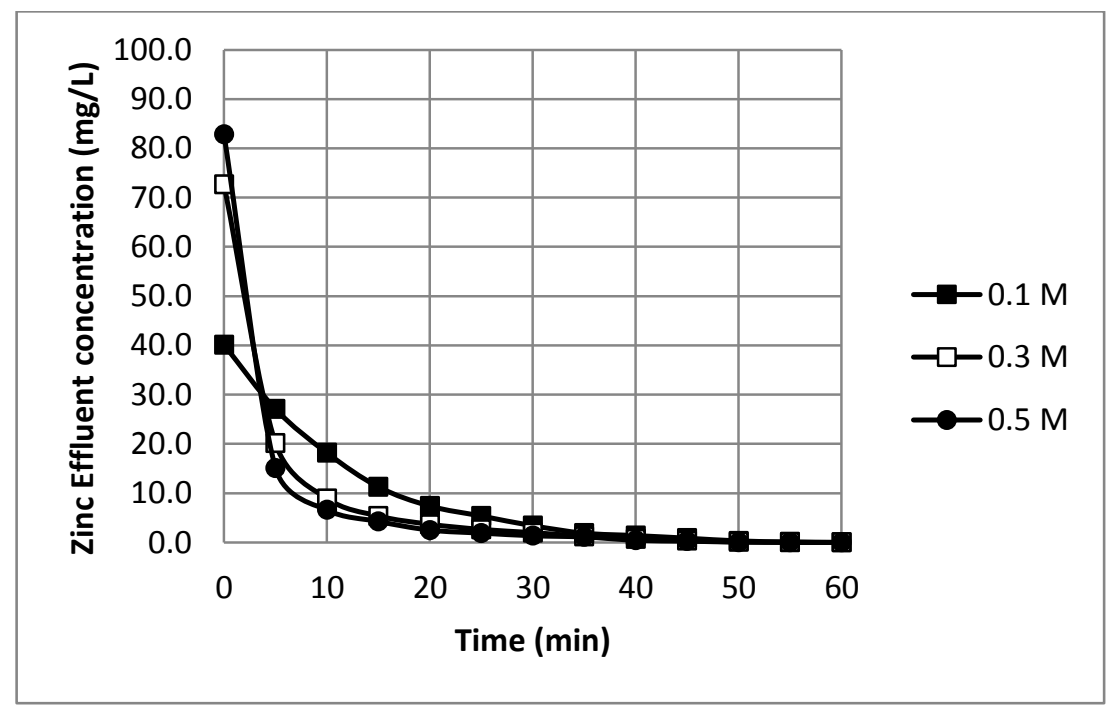

Figure 16: Effect of sulfuric acid concentration on desorption of $\mathrm{Zn}^{2+}$ at flow rate of $0.1 \mathrm{~L} / \mathrm{min}$ 


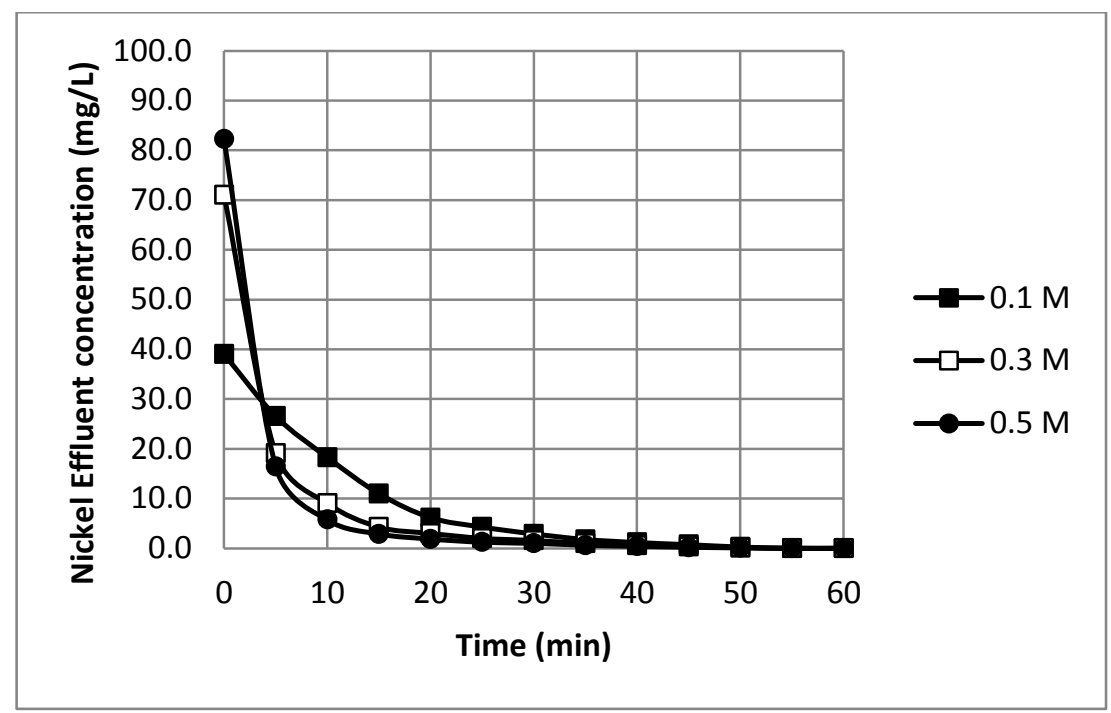

Figure 17: Effect of sulfuric acid concentration on desorption of $\mathrm{Ni}^{2+}$ at flow rate of $0.1 \mathrm{~L} / \mathrm{min}$

\subsubsection{Effect of desorbing agent flow rate}

The effect of flow rate in the range of 0.05 to $0.1 \mathrm{~L} \cdot \mathrm{min}^{-1}$ was investigated. Table 18 summarizes the amount of metal ions desorbed and the elution efficiency for $\mathrm{Zn}^{2+}$ and $\mathrm{Ni}^{2+}$ binary solutions at different flow rates. The results show that at $0.1 \mathrm{M}$, as the flow rate was reduced from 0.1 to 0.05 L.min ${ }^{-1}$, the amount of desorbed ions and the elution efficiency for both $\mathrm{Zn}^{2+}$ and $\mathrm{Ni}^{2+}$ increased significantly. This was mainly due to increases in the resident time of the desorbing agent solution in the column, which resulted in more exchange of metal ions previously adsorbed on the biomass with $\mathrm{H}^{+}$in the eluent solution. This is in agreement with the results of a study on biosorption and desorption of $\mathrm{Cu}^{2+}$ and $\mathrm{Pb}^{2+}$ using chaff by Han et al. (2006b). The authors reported that as the flow rate was decreased from 2.6 to $1.2 \mathrm{~mL} \cdot \mathrm{min}^{-1}$, the metal desorbed and the elution efficiency increased.

Figures 18 and 19 show the desorption profiles of $\mathrm{Zn}^{2+}$ and $\mathrm{Ni}^{2+}$ binary under various flow rate (0.05 to 0.1 L.min ${ }^{-1}$ ). The elution curves for both metal ions exhibited a similar trend, a sharp 
decrease in the beginning followed by a gradual decrease. The desorbing agent concentration and flow rate had significant influences on the overall desorption efficiency and the metal ions recovery. The highest desorption efficiency was observed at the lowest concentration of $0.1 \mathrm{M}$ and the flow rate of $0.05 \mathrm{~L} . \mathrm{min}^{-1}$. Therefore, the flow rate $\left(0.05 \mathrm{~L} . \mathrm{min}^{-1}\right)$ together with $0.1 \mathrm{M}$ $\mathrm{H}_{2} \mathrm{SO}_{4}$ were chosen for the following desorption studies.

Table 18: Effect of the acid flow rate on desorption of $\mathrm{Zn}^{2+}$ and $\mathrm{Ni}^{2+}$

\begin{tabular}{|c|c|c|c|c|}
\hline \multirow{2}{*}{$\begin{array}{c}\text { Eluent Flow rate } \\
(\mathbf{L P M})\end{array}$} & $\begin{array}{c}\text { Metal } \\
\text { desorbed } \\
(\mathbf{m g})\end{array}$ & $\begin{array}{c}\text { Elution } \\
\text { efficiency }\end{array}$ & $\begin{array}{c}\text { Metal } \\
\text { desorbed } \\
(\mathbf{m g})\end{array}$ & $\begin{array}{c}\text { Elution } \\
\text { efficiency }\end{array}$ \\
\hline 0.1 & 49.0 & 83.1 & 46.3 & 82.4 \\
\hline 0.07 & 54.1 & 92.4 & 51.1 & 91.0 \\
\hline 0.05 & 56.5 & 96.4 & 54.4 & 95.2 \\
\hline
\end{tabular}

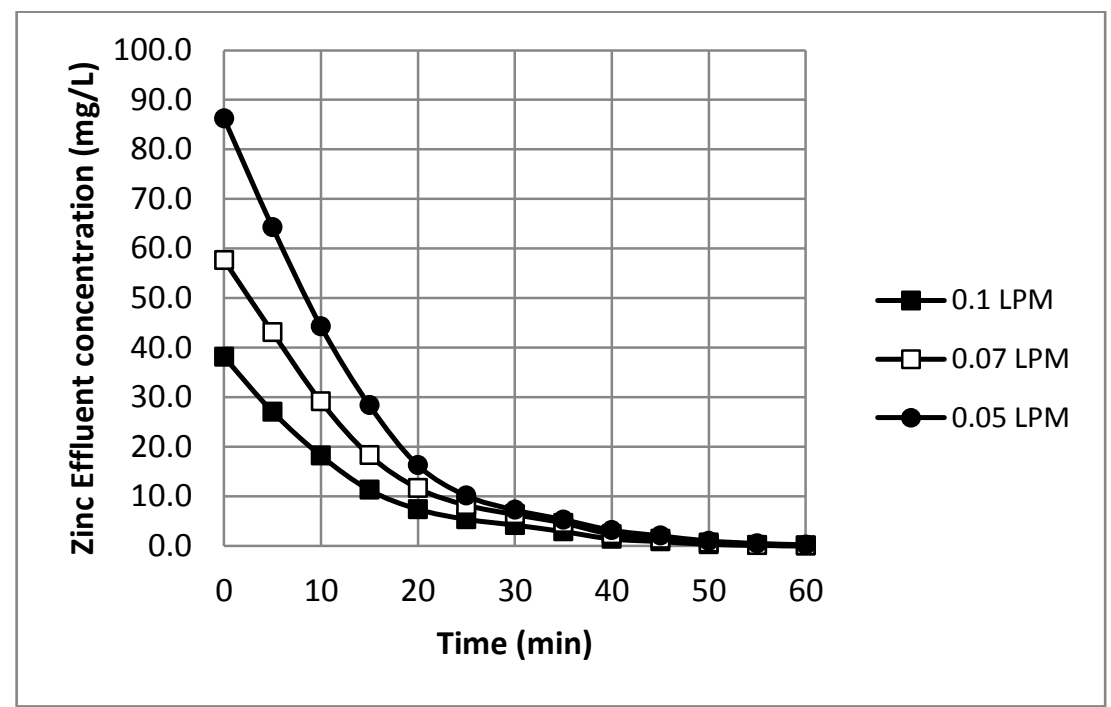

Figure 18: Effect of flow rate on desorption of $\mathrm{Zn}^{2+}$ at $0.1 \mathrm{M}\left(\mathrm{H}_{2} \mathrm{SO}_{4}\right)$ acid concentration 


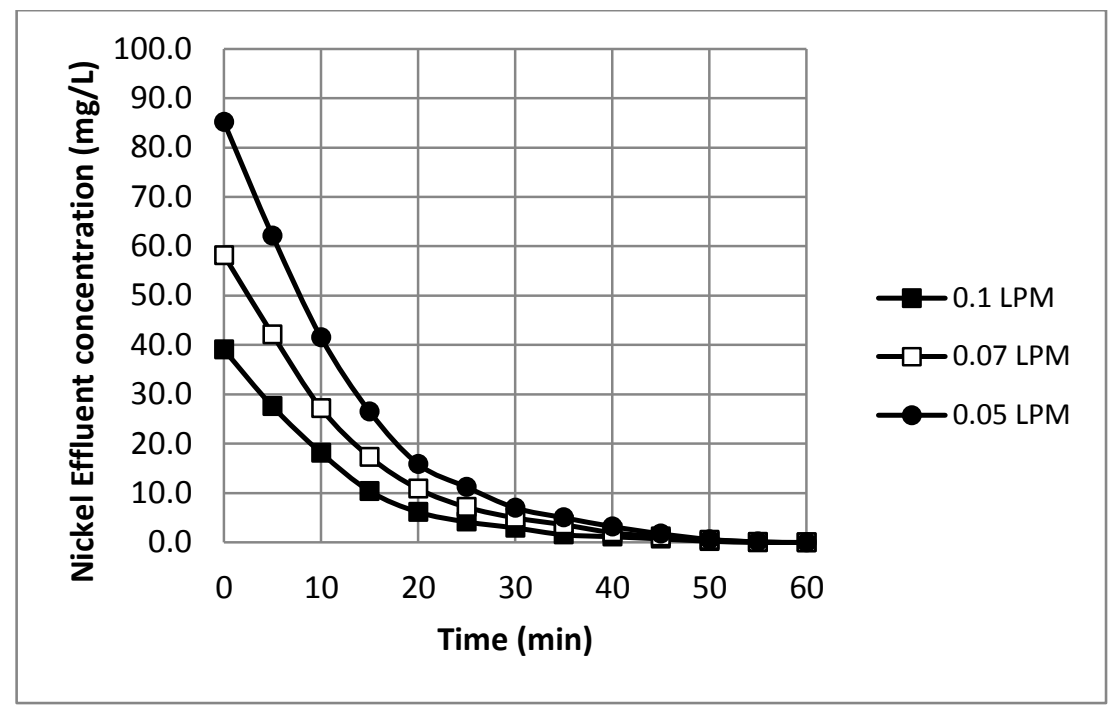

Figure 19: Effect of flow rate on desorption of $\mathrm{Ni}^{2+}$ at $0.1 \mathrm{M}\left(\mathrm{H}_{2} \mathrm{SO}_{4}\right)$ acid concentration

\subsection{Successive removal and recovery of zinc and nickel binary solutions}

The reusability of an adsorption column is another critical issue to be evaluated. This sub-section reports the performance of wheat straw in five successive biosorption/desorption cycles. The biosorption process was carried out at best operation conditions (Section 3.2) until reaching the breakthrough point for $\mathrm{Ni}^{2+}\left(\mathrm{C}_{\mathrm{b}}=2 \mathrm{mg} \cdot \mathrm{L}^{-1}\right)$. The desorption process was the performed by introducing a $0.1 \mathrm{M} \mathrm{H}_{2} \mathrm{SO}_{4}$ solution downward the column at a flow rate of $0.05 \mathrm{~L}^{-\mathrm{min}^{-1}}$ until no trace of zinc and nickel detected in the desorption effluent. The metal uptake capacity, the percentage metal removal and the desorption efficiency were evaluated for all cycles. Each experiment was repeated three times.

Table 19 summarizes the changes in the metal sorption capacity of wheat straw, the percentage metal removal and the elution efficiency for all cycles. At the end of the fifth cycle, the wheat straw was dried at $60^{\circ} \mathrm{C}$ for 24 hours and weighed. The biosorbent weight decreased from the initial weight of $260 \mathrm{~g}$ to $247 \mathrm{~g}$, equivalent to a 5\% weight loss. The results show that the sorption capacity and the percentage metal removal decreased slightly over five 
sorption/desorption cycles. Even though some biomass weight loss was observed at end of five cycles, the wheat straw retained its zinc and nickel uptake capacity in all the five cycles examined. The sorption breakthrough curves for $\mathrm{Zn}^{2+}$ and $\mathrm{Ni}^{2+}$ binary solutions in five biosorption/desorption cycles are presented in Figures 20A and 20B. As seen in Figure 20A and 20B, the breakthrough time decreased and the effluent concentration increased with the number of cycles. The elution curves of zinc and nickel at best operation conditions in all the five cycles is shown in Figures 21A and 21B. The elution curves observed in all the cycles for both metal ions exhibited a similar trend, a sharp decrease at the beginning followed by a gradual decrease. Therefore, the reusability of wheat straw for $\mathrm{Zn}^{2+}$ and $\mathrm{Ni}^{2+}$ removal at set operational conditions is viable. The biosorption/desorption process effectively converted about a simulated wastewater at $10 \mathrm{mg} / \mathrm{L}$ of $\mathrm{Zn}^{2+}$ and $\mathrm{Ni}^{2+}$ each to a concentrated $\mathrm{Zn}^{2+}$ and $\mathrm{Ni}^{2+}$ desorption effluent at about 342 ppm each. Such effluent can be recovered using an electro-deposition process.

Table 19: Sorption and elution process parameters for five sorption-desorption cycles

\begin{tabular}{|c|c|c|c|c|}
\hline $\begin{array}{l}\text { Metal } \\
\text { (Ions) }\end{array}$ & Cycle no. & $\begin{array}{c}\text { Uptake } \\
\text { Capacity }^{1} \\
\text { (mg/g) }\end{array}$ & $\begin{array}{c}\text { Metal } \\
\text { removal }^{2} \\
(\%)\end{array}$ & $\begin{array}{l}\text { Elution } \\
\text { efficiency } \\
(\%)\end{array}$ \\
\hline Zinc & 1 & $0.227 \pm 0.001$ & 98.2 & $96.9 \pm 0.2$ \\
\hline & 2 & $0.223 \pm 0.001$ & 96.6 & $95.4 \pm 0.4$ \\
\hline & 3 & $0.220 \pm 0.001$ & 95.8 & $93.6 \pm 0.4$ \\
\hline & 4 & $0.218 \pm 0.001$ & 94.9 & $92.3 \pm 0.4$ \\
\hline & 5 & $0.216 \pm 0.001$ & 93.2 & $91.3 \pm 0.5$ \\
\hline Nickel & 1 & $0.220 \pm 0.001$ & 95.2 & $95.8 \pm 0.3$ \\
\hline & 2 & $0.219 \pm 0.002$ & 94.4 & $94.4+0.3$ \\
\hline & 3 & $0.216 \pm 0.001$ & 93.7 & $92.9 \pm 0.3$ \\
\hline & 4 & $0.215 \pm 0.001$ & 93.1 & $91.6 \pm 0.3$ \\
\hline & 5 & $0.213 \pm 0.001$ & 92.4 & $90.2+0.5$ \\
\hline
\end{tabular}

\footnotetext{
${ }^{1}$ The time step for metal uptake $=55(\mathrm{~min})$
}

${ }^{2}$ The time step for $\%$ removal $=55(\mathrm{~min})$ 


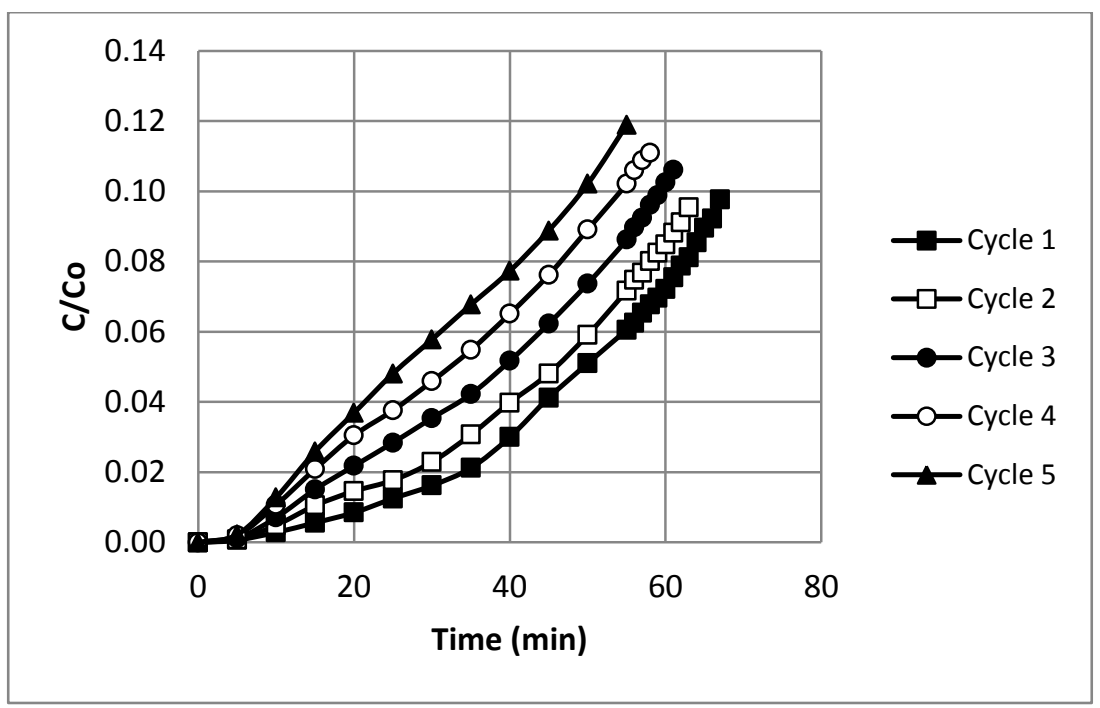

A)

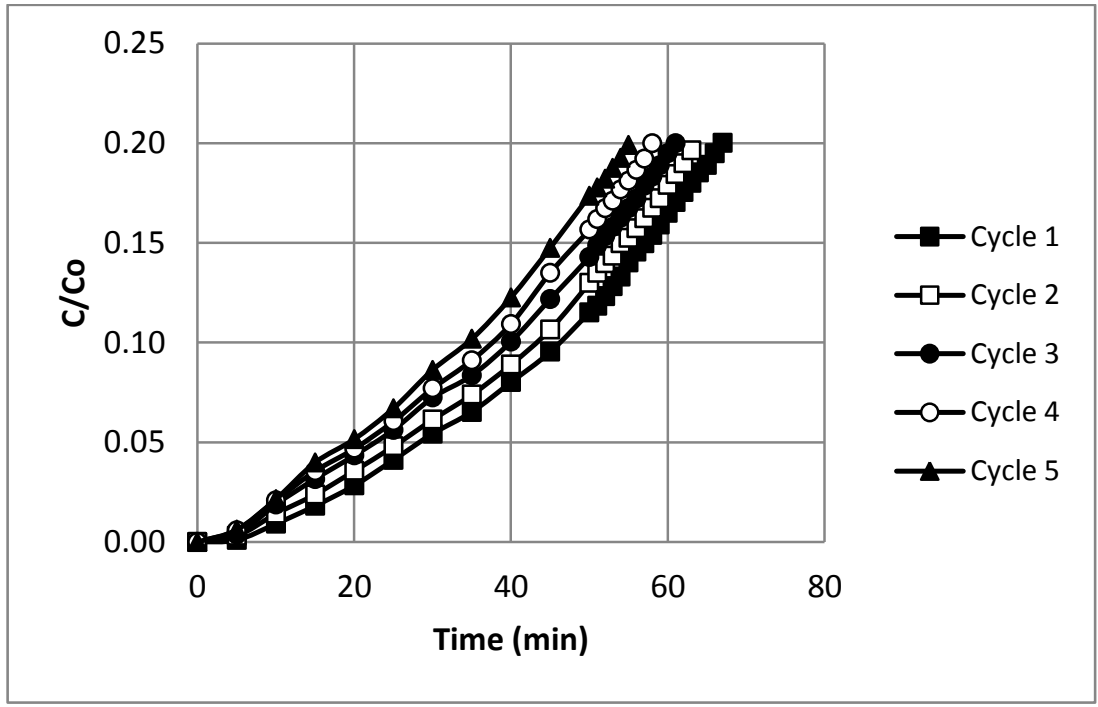

B)

Figure 20: Breakthrough curves for $A$ ) zinc and B) nickel by wheat straw for five biosorption/desorption cycles $\left(\right.$ bed depth $=2 \mathrm{~m}$; volumetric flow rate $=0.1 \mathrm{~L} / \mathrm{min} ;\left[\mathrm{Zn}^{2+}\right]_{0}=\left[\mathrm{Ni}^{2+}\right]_{0}=$ 10 ppm) 


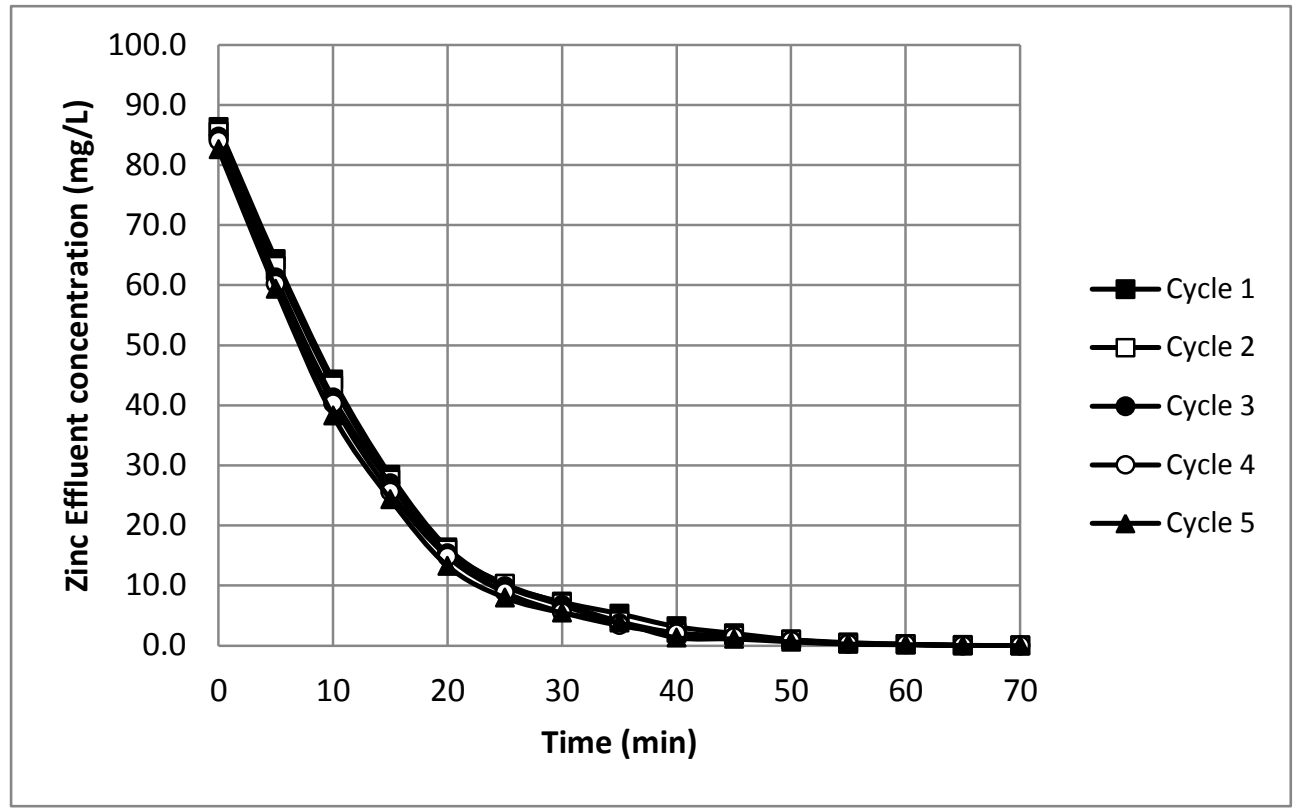

A)

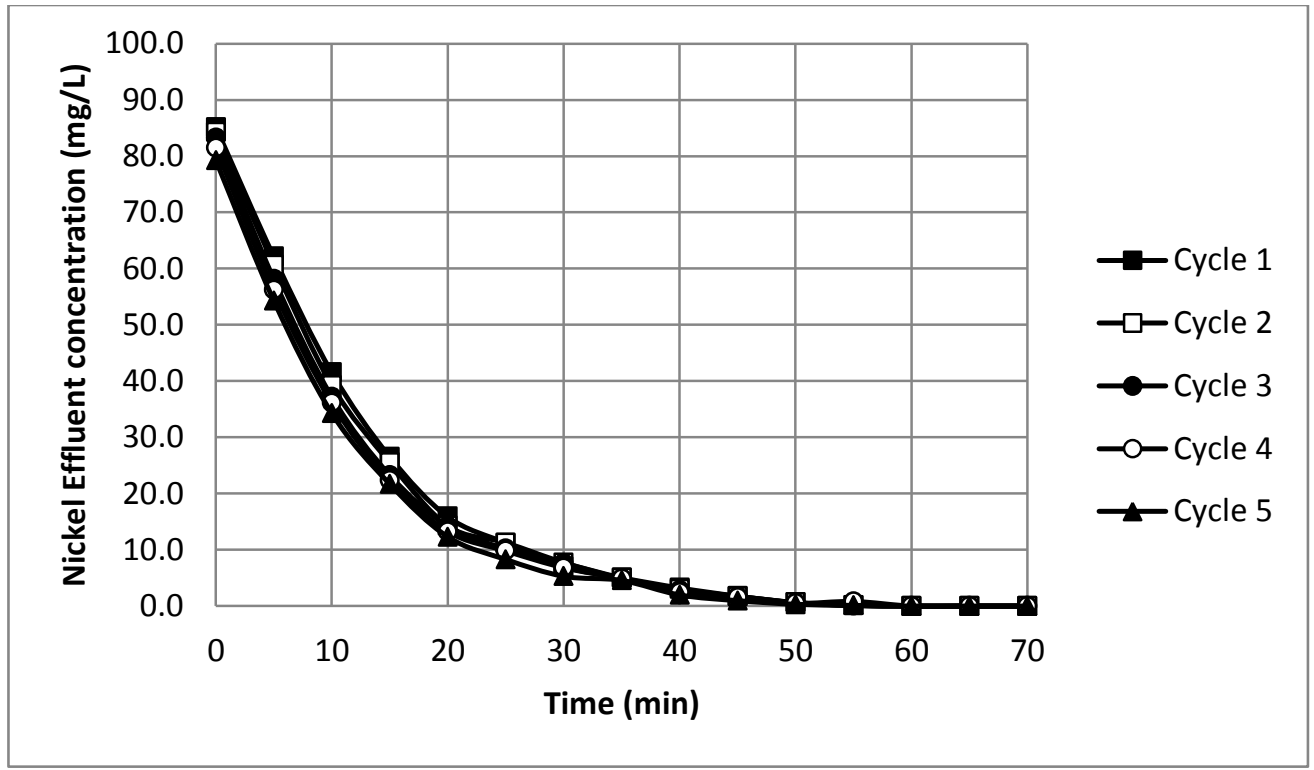

B)

Figure 21: Elution curves for A) zinc and B) nickel by Wheat straw for five biosorption/desorption cycles 


\subsection{Recovery of desorbed zinc and nickel: electro-deposition}

In the integrated treatment (Section 4.7), the results showed good efficiency in zinc and nickel recovery throughout the five sequential cycles. The concentrated $\mathrm{Zn}^{2+}$ and $\mathrm{Ni}^{2+}$ binary solutions from the desorption step were introduced into an acid $\mathrm{Zn}-\mathrm{Ni}$ alloy plating bath as electrolyte solutions. Table 20 shows zinc and nickel binary concentrations from the integrated treatment.

Table 20: Characteristics of integrated wastewater treatment

\begin{tabular}{|l|l|}
\hline Metal Ion & Unit \\
\hline Zinc & $342.68 \mathrm{ppm}$ \\
\hline Nickel & $323.43 \mathrm{ppm}$ \\
\hline
\end{tabular}

\subsubsection{Zn-Ni electro-deposition recovery process}

There are several factors that affect the performance of an electro-deposition process. The electrolyte $\mathrm{pH}$ is one of the most important factors that have a crucial effect on the metal removal. Doan et al. (2003) studied the effect of the electrolyte $\mathrm{pH}$ on $\mathrm{Zn}^{2+}$ and $\mathrm{Ni}^{2+}$ binary electro-deposition. The data indicated that the best metal deposition occurred at an electrolyte $\mathrm{pH}$ of about 6.0. Simonsson (1984) also reported the highest rate of zinc recovery was accomplished at the solution $\mathrm{pH}$ of about 6.0 , and increasing $\mathrm{pH}$ lead to chemical precipitation of zinc hydroxide. Likewise, Orhan et al. (2002) studied nickel deposition from an aqueous solution. They reported that the highest nickel deposition was at the bulk pH of about 5.5-6.0. Therefore, in the current study, the $\mathrm{pH}$ value of the electrolyte was set at 5.5-6.

In the current study, the effect of current density and liquid flux on electro-deposition performance was studied. 


\subsubsection{Effect of current density}

Current density is one of the critical factors controlling the deposition rate. In this study, the effect of the current density in a range of 3.75 to $27.50 \mathrm{~mA} \cdot \mathrm{cm}^{-2}$ on the electro-deposition of $\mathrm{Zn}^{2+}$ and $\mathrm{Ni}^{2+}$ binary solutions was investigated. Shown in Tables 22 and 23 , as the current density was increased from 3.75 to $27.50 \mathrm{~mA} . \mathrm{cm}^{-2}, \mathrm{Zn}^{2+}$ removal increased about 3.4 times. On the other hand, a significant decrease in $\mathrm{Ni}^{2+}$ removal was observed.

According to the standard half-cell potential of $\mathrm{Zn}^{2+}(-0.76 \mathrm{~V})$ and $\mathrm{Ni}^{2+}(-0.23 \mathrm{~V}), \mathrm{Ni}^{2+}$ should deposit on the cathode more readily than $\mathrm{Zn}^{2+}$. As shown in Tables 21 and 22, at the lowest current density $\left(9.75 \mathrm{~mA} . \mathrm{cm}^{-2}\right)$ normal co-deposition occurred, but as the current density was increased, anomalous co-deposition took place. This may be due to the fact that at a high current density, more water would be hydrolyzed according to reaction (R3) (Section 2.9.4), producing $\mathrm{OH}^{-}$for the formation of zinc hydroxide at the cathode surface. This would limit the sites on the electrode that are available for $\mathrm{Ni}^{2+}$ deposition. On the other hand, at low current density, metals in the solution would be in their ionic forms since the critical $\mathrm{pH}$ for the formation of both zinc hydroxide and nickel hydroxide was not reached. Thus, $\mathrm{Ni}^{2+}$ would be deposited more favourably than $\mathrm{Zn}^{2+}$ due to its higher standard reduction potential (Bret and Bret, 1993; Crow, 1998). AbouKrisha et al. (2007) studied co-deposition of Zn-Ni alloy using sulphate electrolytes. The authors reported that the percentage of nickel in the deposited $\mathrm{Zn}-\mathrm{Ni}$ alloy decreased from $82.9 \%$ to $11.5 \%$ while the $\mathrm{Zn}$ content increased from $17.1 \%$ to $88.5 \%$ with increases in the current density from 1.0 to $30 \mathrm{~mA} \cdot \mathrm{cm}^{-2}$. Similar results were also observed by other researchers (Fedrizzi et al., 1992; Roventi et al., 2000; Lehmberg et al., 2005). 
The effect of current density on the effluent metal ions is presented in Figure 22A and 22B. As the current density increased, $\mathrm{Zn}^{2+}$ concentration decreased more quickly from the initial concentration of $342.7 \mathrm{mg} . \mathrm{L}^{-1}$ to the effluent concentration limit of $2 \mathrm{mg} . \mathrm{L}^{-1}$. The times to reach the concentration limit at current densities of 3.75, 9.30, 19.94 and $27.50 \mathrm{~mA} . \mathrm{cm}^{-2}$ were 55.6, 26, 20 and 17.5 hours, respectively. On the other hand, the effluent concentration limit for $\mathrm{Ni}^{2+}$ could not be reached over 72 hours when the current density was set at $9.30 \mathrm{~mA} . \mathrm{cm}^{-2}$ or higher. Therefore, the current density of $3.75 \mathrm{~mA} / \mathrm{cm}^{2}$ was selected to use in the rest of the electrodeposition study.

In this study, two forms of deposit were observed: a layer of gray metallic deposit and a pale green deposit, which was spongy and loosely attached to the cathode surface. At a high current density, zinc-nickel deposits had grayish appearance which consists of mainly metallic zinc and some metallic nickel and zinc hydroxide. While, the pale green loose deposit is mainly nickel hydroxide with some zinc hydroxide. Similar observation was reported by Abibsi et al. (1991) and Sheela et al. (2002). On the other hand, at low current density (nickel-rich), the gray deposit was semi-bright.

Table 21: Removal of $\mathrm{Zn}^{2+}$ at 12 hours of electro-deposition at a flow rate of $9.88 \mathrm{~L}^{\mathrm{min}}{ }^{-1}$

\begin{tabular}{|c|c|c|}
\hline $\begin{array}{c}\text { Concentration } \\
(\mathbf{p p m})\end{array}$ & $\begin{array}{c}\text { Current Density } \\
\left(\mathrm{mA} \cdot \mathrm{cm}^{-2}\right)\end{array}$ & $\begin{array}{c}\text { Removal } \\
\text { Percentage (\%) }\end{array}$ \\
\hline \multirow{4}{*}{342.7} & 3.75 & 25.9 \\
\cline { 2 - 3 } & 9.30 & 50.0 \\
\cline { 2 - 3 } & 19.94 & 75.2 \\
\cline { 2 - 3 } & 27.50 & 89.1 \\
\hline
\end{tabular}


Table 22: Removal of $\mathrm{Ni}^{2+}$ at 12 hours of electro-deposition at a flow rate of $9.88 \mathrm{~L} . \mathrm{min}^{-1}$

\begin{tabular}{|c|c|c|}
\hline $\begin{array}{c}\text { Concentration } \\
(\mathbf{p p m})\end{array}$ & $\begin{array}{c}\text { Current Density } \\
\left(\mathrm{mA} \cdot \mathrm{cm}^{-2}\right)\end{array}$ & $\begin{array}{c}\text { Removal } \\
\text { Percentage (\%) }\end{array}$ \\
\hline \multirow{4}{*}{323.4} & 3.75 & 59.2 \\
\cline { 2 - 3 } & 9.30 & 29.8 \\
\cline { 2 - 3 } & 19.94 & 19.2 \\
\cline { 2 - 3 } & 27.50 & 4.90 \\
\hline
\end{tabular}

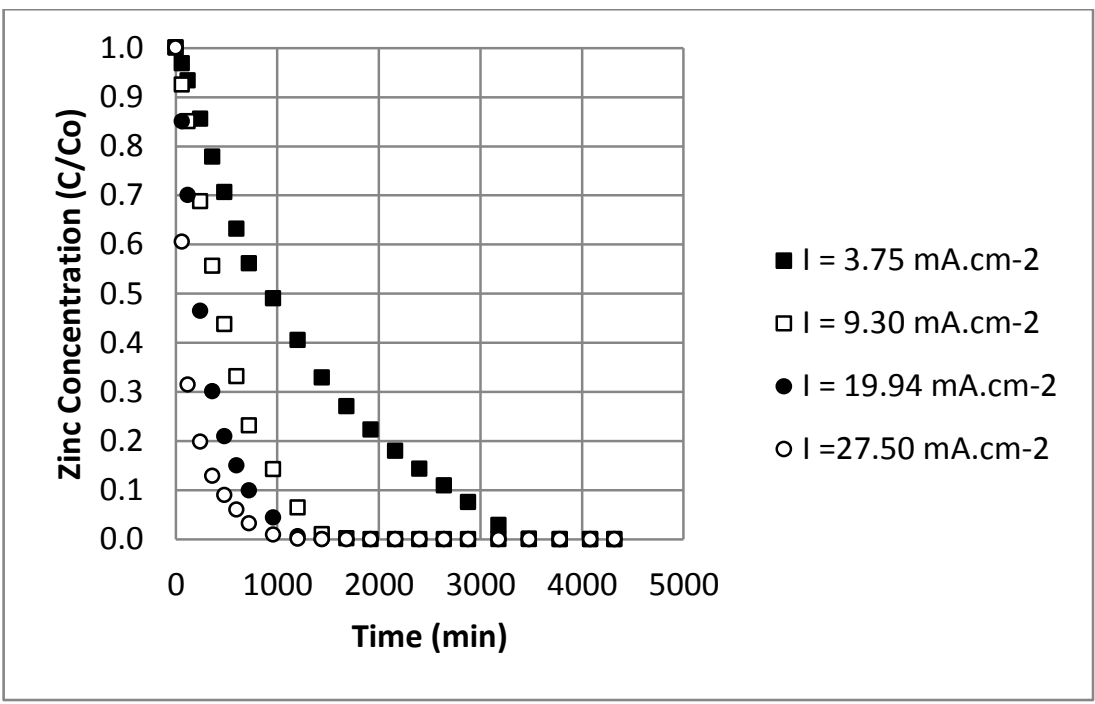

A)

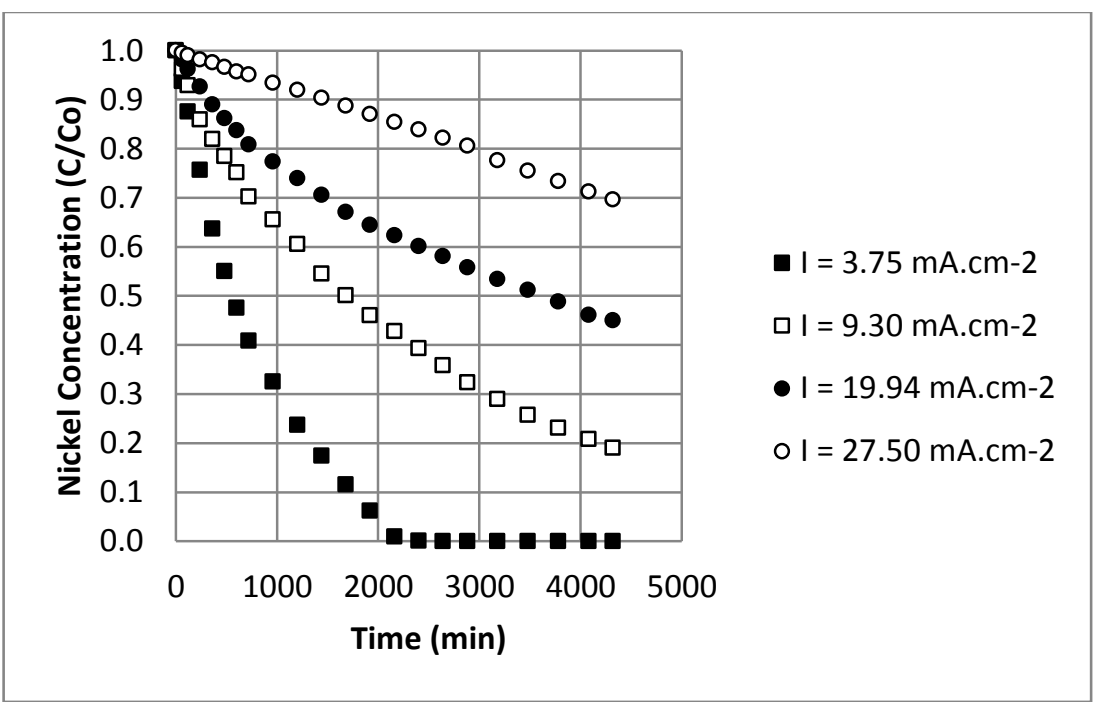

B)

Figure 22: Effect of current density on (A) $\mathrm{Zn}^{2+}$ and (B) $\mathrm{Ni}^{2+}$ electro-deposition at $9.88 \mathrm{~L} . \mathrm{min}^{-1}$ 


\subsubsection{Effect of volumetric flow rate}

The liquid flow rate is another important parameter that needs to be controlled during the electrodeposition process. Varied flow rates from 0.90 to $9.88 \mathrm{~L} \cdot \mathrm{min}^{-1}\left(0.0015\right.$ to $\left.0.0165 \mathrm{~m}^{3} \cdot \mathrm{m}^{-2} \cdot \mathrm{s}^{-1}\right)$ were used in this study while maintaining the bulk $\mathrm{pH}$ at $5.5-6$ and current density of 3.75 $\mathrm{mA} / \mathrm{cm}^{2}$. Figure 23 presents the effect of the electrolyte flow rate on the percentage removal of $\mathrm{Zn}^{2+}$ and $\mathrm{Ni}^{2+}$ binary solutions over 24 hours of operation. The results indicate that $\mathrm{Ni}^{2+}$ removal increased slightly about $11 \%$ as the flow rate was increased while the percentage removal of $\mathrm{Zn}^{2+}$ increased more substantially about $17 \%$. This is because of as flow increased, the mass transfer of metal ions from the bulk liquid to the cathode increased. Additionally, since there was a higher initial concentration of $\mathrm{Zn}$ ions than $\mathrm{Ni}$ ions in electrolyte solution originally, hence, a high initial concentration provides a high driving force for the deposition process.

Similar trend was reported by Doan and Saidi (2008) for electro-deposition of $\mathrm{Zn}^{2+}$ and $\mathrm{Ni}^{2+}$ binary at varied flow rates from 0.0021 to $0.017 \mathrm{~m}^{3} \cdot \mathrm{m}^{-2} \cdot \mathrm{s}^{-1}$. The metal electro-deposition curves at varied flow rate are presented in Figures 24A and 24B. The results indicated that as the flow rate was increased, the required time to reduce the effluent heavy metal concentration down to the discharge (2 ppm) limit decreased. Therefore, the best operation conditions to maintain the concentration of $\mathrm{Zn}^{2+}$ and $\mathrm{Ni}^{2+} \leq 2 \mathrm{mg} \cdot \mathrm{L}^{-1}$ is at the current density of $3.75 \mathrm{~mA} \cdot \mathrm{cm}^{-2}$ and the flow rate of $9.88 \mathrm{~L} \cdot \mathrm{min}^{-1}$ for a total treatment time of 60 hours. 


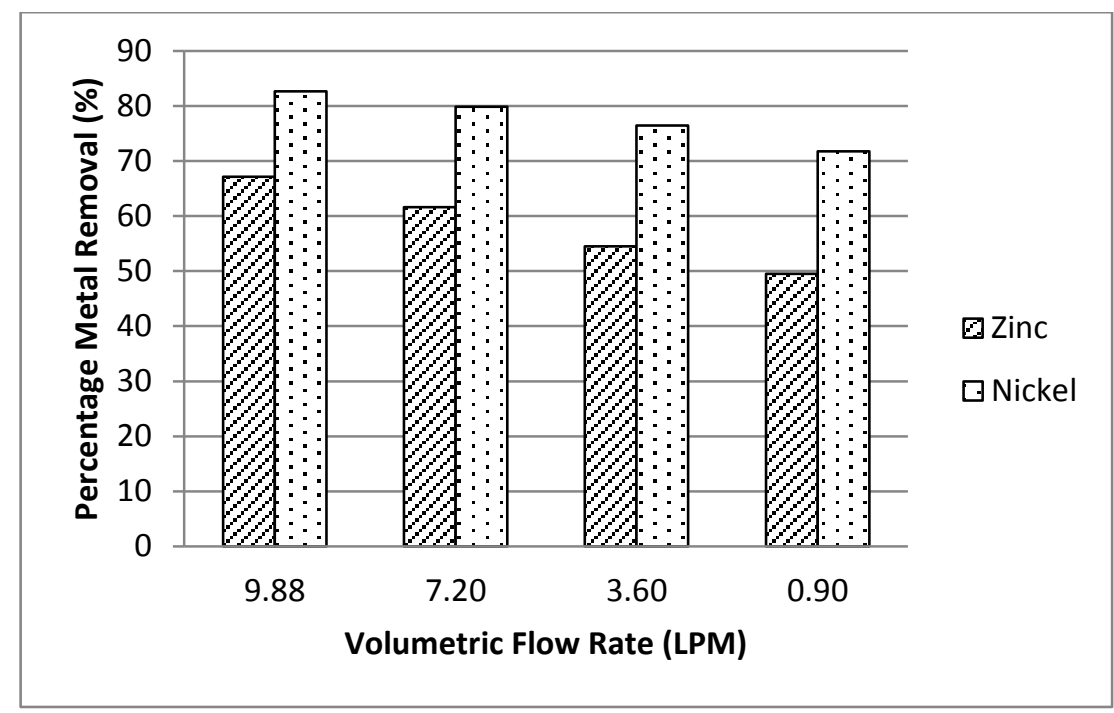

Figure 23: Effect of flow rate on the removal of $\mathrm{Zn}^{2+}$ and $\mathrm{Ni}^{2+}$ at given current density of 3.75 mA.cm ${ }^{-2}$ (24 hour) 


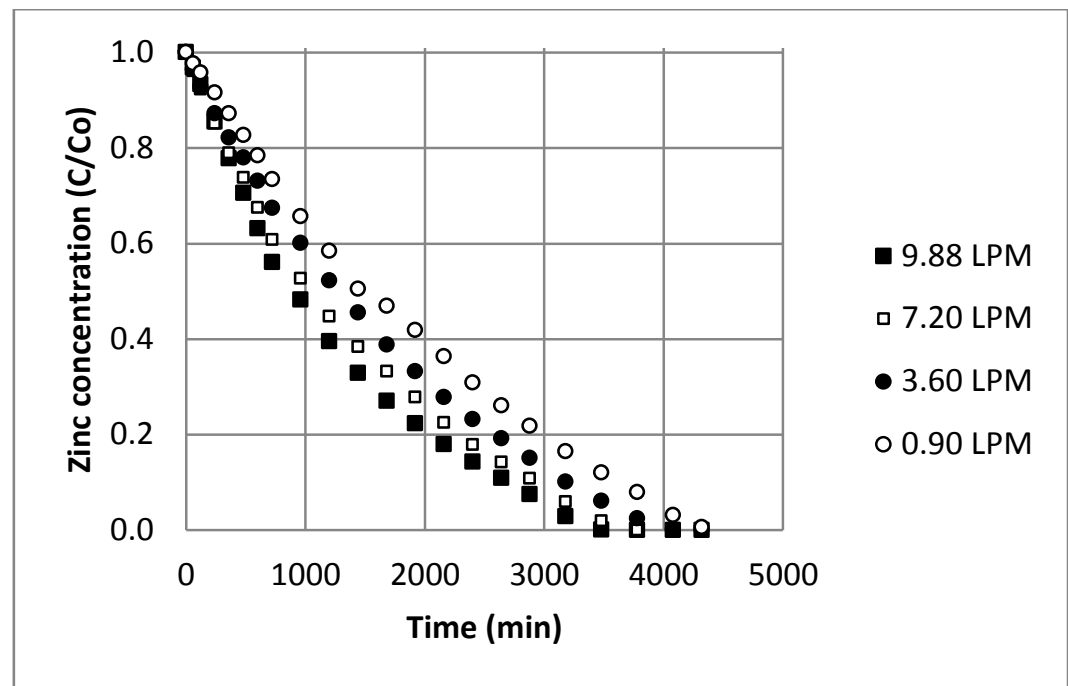

A)

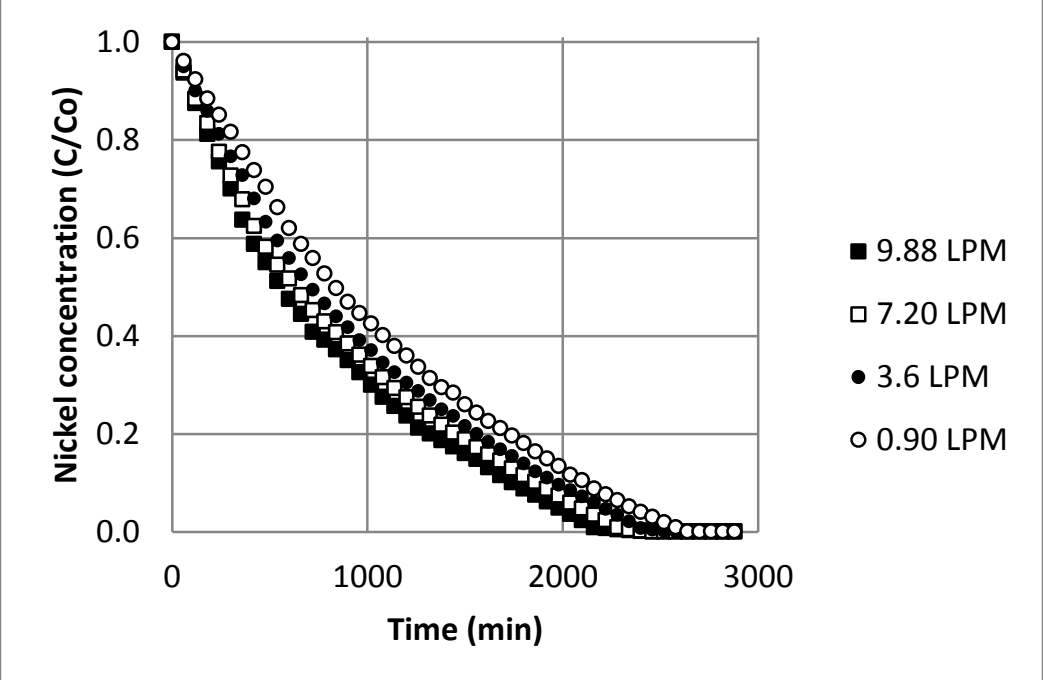

B)

Figure 24: Effect of volumetric flow rate on $\mathrm{A}$ ) $\mathrm{Zn}^{2+}$ and $\mathrm{B}$ ) $\mathrm{Ni}^{2+}$ reduction during 72 hours of treatment

\subsection{Electro-deposition kinetics}

In the present study, the variation of the metal concentration with the treatment time exhibited an exponential decay (Figures 24A and 24B), indicating that the removal of the ions followed a firstorder kinetics that can be expressed as:

$r=\frac{d C}{d t}=-k C$ 
Integrating Equation (4-1) gives:

$\operatorname{Ln}\left(\frac{C}{C_{o}}\right)=-k t$

Where $k\left(\mathrm{~min}^{-1}\right)$ is the first-order rate constant and $r(\mathrm{mg} / \mathrm{L} . \mathrm{min})$ is the removal rate.

As can be seen in Figures 25 and 26, the values of the coefficient of determination for both $\mathrm{Zn}^{2+}$ and $\mathrm{Ni}^{2+}$ are closed to 1 , indicating that first-order model is suitable to describe the kinetics of $\mathrm{Zn}^{2+}$ and $\mathrm{Ni}^{2+}$ deposition. The values of $\mathrm{k}$ were found to increase from 0.0005 to $0.0008 \mathrm{~min}^{-1}$ for $\mathrm{Zn}^{2+}$ and 0.001 to $0.0014 \mathrm{~min}^{-1}$ for $\mathrm{Ni}^{2+}$ with increases in the flow rate from 0.90 to $9.88 \mathrm{~L} \cdot \mathrm{min}^{-1}$. This is comparable to the data obtained for deposition of $\mathrm{Zn}^{2+}$ by Doan and Saidi (2008). However, the rate constant of $\mathrm{Ni}^{2+}$ was about 5 times higher than their reported values. This may be due to the fact that in Doan and Saidi's work the solution also contained LAS (a contaminate) that might compete with metal ions for electrons at the cathode. LAS compound was not present in the solution used in the present study. 


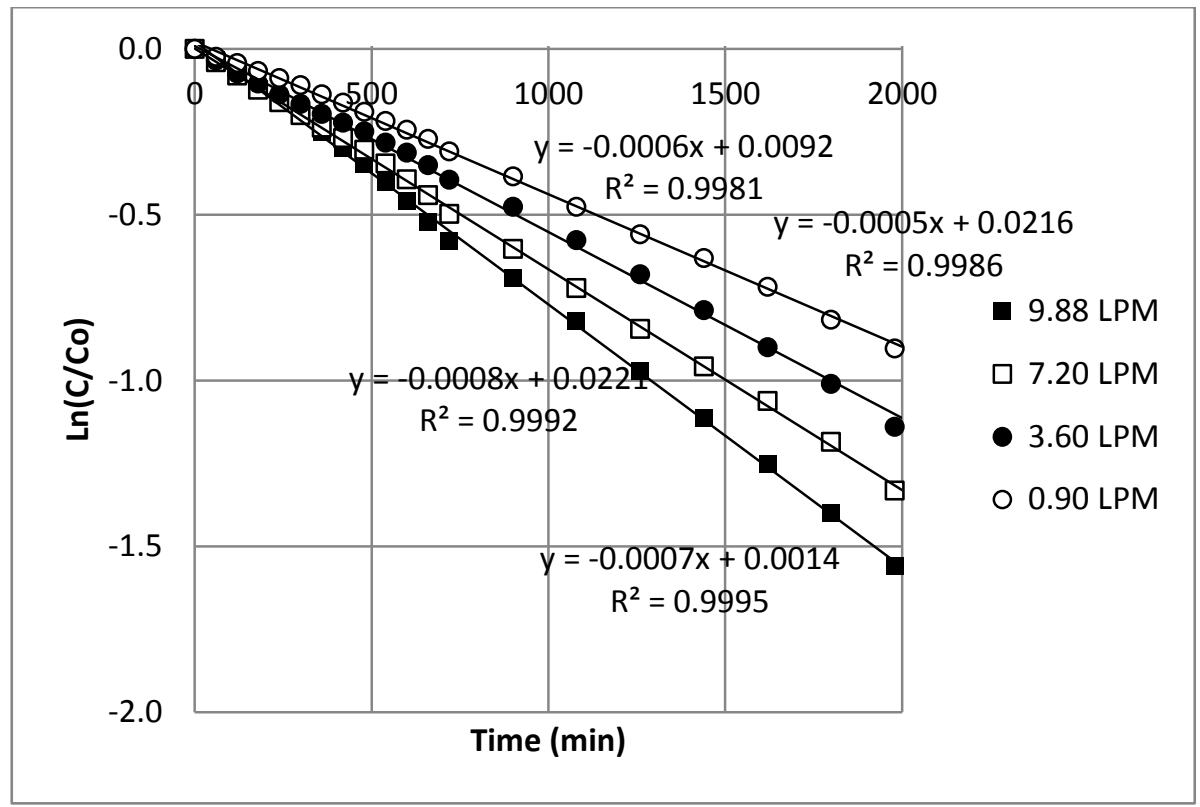

Figure 25: $\mathrm{Ln}(\mathrm{C} / \mathrm{Co})$ versus time for $\mathrm{Zn}^{2+}$ depositions at different flow rates

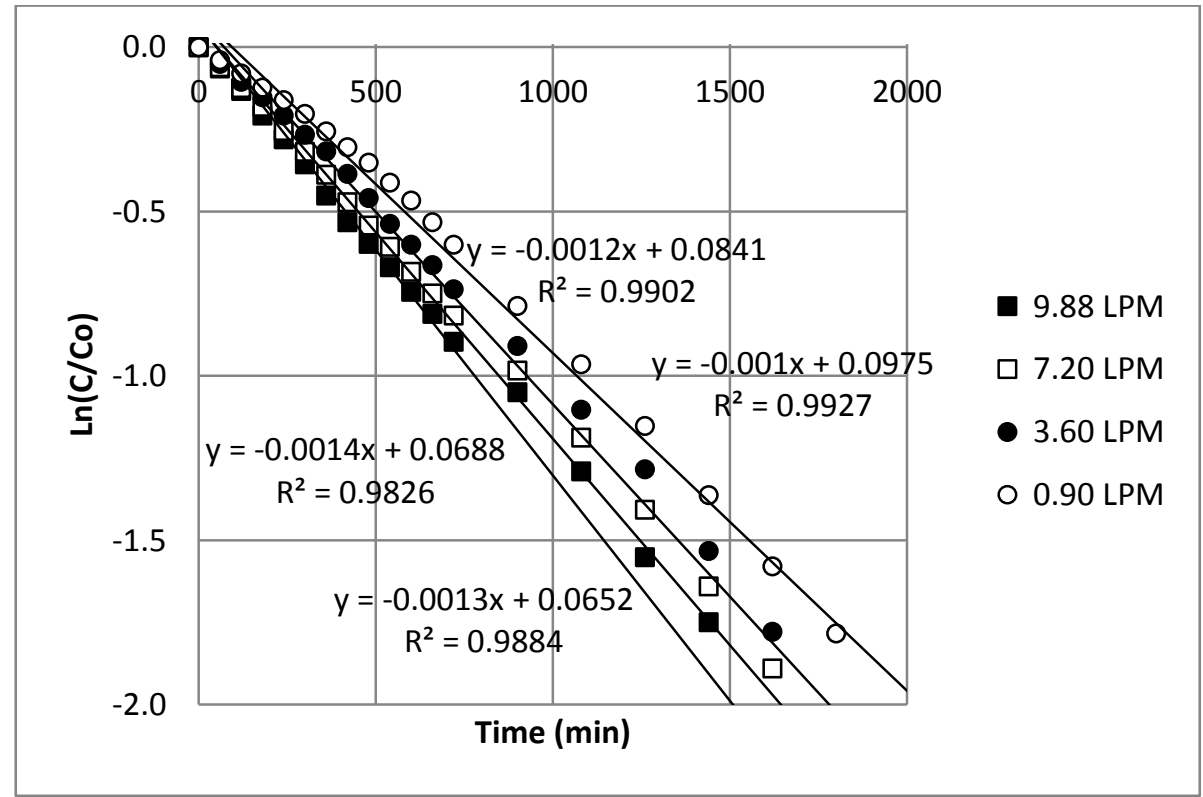

Figure 26: $\mathrm{Ln}(\mathrm{C} / \mathrm{Co})$ versus time for $\mathrm{Ni}^{2+}$ depositions at different flow rates

Furthermore, for design and performance evaluation of an electro-deposition process, the mass transfer coefficient is required. The mass transfer coefficient, $k_{\mathrm{c}}$, can be estimated using the following equation (Bird et al., 2002). 
$k_{c}=\frac{r_{m}}{A \cdot\left(C-C_{S}\right)}$

where $r_{m}$ is the mass transfer rate of metal ions from the bulk liquid to a flat plate cathode $\left(\mathrm{cm}^{3} \cdot \mathrm{mg} / \mathrm{L} \cdot \mathrm{min}\right), \mathrm{C}_{\mathrm{s}}$ is the metal concentration at the cathode surface $\left(\mathrm{mg} \cdot \mathrm{L}^{-1}\right)$ and $\mathrm{A}$ is the cathode surface area $\left(\mathrm{cm}^{2}\right) . \mathrm{C}_{\mathrm{s}}$ could be assumed to be zero since the metal deposition is a very fast reaction (Treybal, 1987). By combining Equations (4-1) and (4-3), the mass transfer coefficient, $\mathrm{k}_{\mathrm{c}}$, can be expressed as below:

$k_{c}=k \frac{V}{A}$

where $\mathrm{V}$ is the volume of electrolyte (L). From kinetic rate constant values obtained from the experimental data, values of the mass transfer coefficient can be calculated from Equation (4-4). Apparent rate constants, $\mathrm{k}$, and average mass transfer coefficients, $\mathrm{k}_{\mathrm{C}}$, are summarized in Tables 23 and 24.

Table 23: Apparent first order rate constants for zinc ion reduction and average mass transfer coefficients during 72 hours of treatment

\begin{tabular}{|l|l|l|}
\hline $\begin{array}{c}\text { Volumetric Flow } \\
\text { Rate } \\
(\mathrm{LPM})\end{array}$ & $\begin{array}{c}\text { Apparent rate } \\
\text { constant, } \mathrm{k} \\
\left(\mathrm{min}^{-1}\right)\end{array}$ & $\begin{array}{c}\text { Average mass } \\
\text { transfer } \\
\text { coefficient, } \mathrm{k}_{\mathrm{c}} \\
\left(\mathrm{cm} \cdot \mathrm{min}^{-1}\right)\end{array}$ \\
\hline 0.90 & 0.0005 & $0.972 \times 10^{-2}$ \\
\hline 3.60 & 0.0006 & $1.173 \times 10^{-2}$ \\
\hline 7.20 & 0.0007 & $1.362 \times 10^{-2}$ \\
\hline 9.88 & 0.0008 & $1.555 \times 10^{-2}$ \\
\hline
\end{tabular}

Table 24: Apparent first order rate constants for Nickel ion reduction and average mass transfer coefficients during 72 hours of treatment

\begin{tabular}{|l|l|l|}
\hline $\begin{array}{c}\text { Volumetric Flow } \\
\text { Rate } \\
(\mathrm{L} / \mathrm{min})\end{array}$ & $\begin{array}{c}\text { Apparent rate } \\
\text { constant, } \mathrm{k} \\
\left(\mathrm{min}^{-1}\right)\end{array}$ & $\begin{array}{c}\text { Average mass } \\
\text { transfer } \\
\text { coefficient, } \mathrm{k}_{\mathrm{c}} \\
\left(\mathrm{cm} \cdot \mathrm{min}^{-1}\right)\end{array}$ \\
\hline 0.90 & 0.0010 & $1.943 \times 10^{-2}$ \\
\hline 3.60 & 0.0012 & $2.334 \times 10^{-2}$ \\
\hline 7.20 & 0.0013 & $2.531 \times 10^{-2}$ \\
\hline 9.88 & 0.0014 & $2.722 \times 10^{-2}$ \\
\hline
\end{tabular}


Furthermore, the dimensionless $\mathrm{J}_{\mathrm{D}}$ factor for mass transfer is often used to correlate the experimental data. The $\mathrm{J}_{\mathrm{D}}$ factor can be expressed as:

$J_{D}=\frac{S h}{R e . S c^{1 / 3}}$

or

$J_{D}=\frac{k_{c} \cdot L}{D_{A B} \cdot \operatorname{Re} \cdot S c^{1 / 3}}$

Where Sh is the Sherwood number $\left(\frac{k_{c} \cdot L}{D_{A B}}\right), \operatorname{Re}$ is the Reynolds number $\left(\frac{D . \rho \cdot u}{\mu}\right), \mathrm{Sc}$ is the Schmidt number $\left(\frac{\mu}{\rho \cdot D_{A B}}\right), L$ is the characteristic length (in the present study, it is the hydraulic diameter of the opened-channel electro-cell, $L=0.086 \mathrm{~m}), D_{\mathrm{AB}}$ is the diffusivity of the metal ion in liquid, $u$ is the fluid superficial velocity, $\mu$ and $\rho$ are fluid viscosity and density, respectively. The physical and transport properties of the electrolyte used in the calculations are given in Table 25 . The values of the $\mathrm{J}_{\mathrm{D}}$ factor for mass transfer obtained are plotted with the Reynolds number in Figure 27. The correlations for the $\mathrm{J}_{\mathrm{D}}$ factor can thus be written as:

$$
\begin{aligned}
& J_{D}=7.08 \mathrm{Re}^{-0.815} \text { for } \mathrm{Zn}^{2+} \\
& \mathrm{J}_{\mathrm{D}}=20.01 \mathrm{Re}^{-0.864} \text { for } \mathrm{Ni}^{2+}
\end{aligned}
$$

By equating Equations (4-6) and (4.7) and rearranging the resultant equation with Re placed in on side of equation, one can see that the mass transfer coefficient, $\mathrm{k}_{\mathrm{c}}$, for $\mathrm{Zn}^{2+}$ is proportional to Reynolds number, hence, the liquid velocity in the electrochemical cell to the exponent of 0.18 (equation (4-10)). Similarly, by combining Equations (4-6) and (4-8), the mass transfer coefficient for $\mathrm{Ni}^{2+}$ appear to be dependent to liquid velocity $\left(\mathrm{kc} \propto \mathrm{u}^{0.14}\right.$ ) (equation (4-11)). The correlations in Equations (4-10) and (4-11) allow estimations of the mass transfer coefficient at varied the liquid velocity in the electrochemical cell. 


$$
\frac{k_{C} \cdot L}{D_{A B} \cdot S c^{1 / 3}}=R e^{0.18} \text { for } \mathrm{Zn}^{2+}
$$

or

$$
\begin{aligned}
& \frac{k_{c} \cdot L}{D_{A B} \cdot S c^{1 / 3}}=\left(\frac{D . \rho \cdot u}{\mu}\right)^{0.18} \text { for } \mathrm{Zn}^{2+} \\
& \frac{k_{c} \cdot L}{D_{A B} \cdot S c^{1 / 3}}=\left(\frac{D \cdot \rho \cdot u}{\mu}\right)^{0.14} \text { for } \mathrm{Ni}^{2+}
\end{aligned}
$$

Table 25: Physical properties of the electrolyte solution at $25 \circ \mathrm{C}$

\begin{tabular}{|l|l|l|}
\hline & \multicolumn{1}{|c|}{$\mathbf{Z n}^{2+}$} & \multicolumn{1}{c|}{$\mathbf{N i}^{2+}$} \\
\hline Density, $\rho\left(\mathrm{kg} \cdot \mathrm{m}^{-3}\right)^{1}$ & 946 & 946 \\
\hline Viscosity, $\mu\left(\mathrm{kg} \cdot \mathrm{m}^{-1} \cdot \mathrm{s}^{-1}\right)^{1}$ & 0.000964 & 0.000964 \\
\hline Diffusion coefficient, $\mathrm{D}_{\mathrm{AB}}\left(\mathrm{m}^{2} . \mathrm{s}^{-1}\right)^{2}$ & $7.02 \times 10^{-10}$ & $6.13 \times 10^{-10}$ \\
\hline
\end{tabular}

${ }^{1}$ measured values using a pycnometer for density (VWR Canada, Mississauga,Ontario) and a viscometer (model V-2000 Series II, Cannon Instrument Co., PA, USA)

${ }^{2}$ esminated values (Bird et al., 2002)

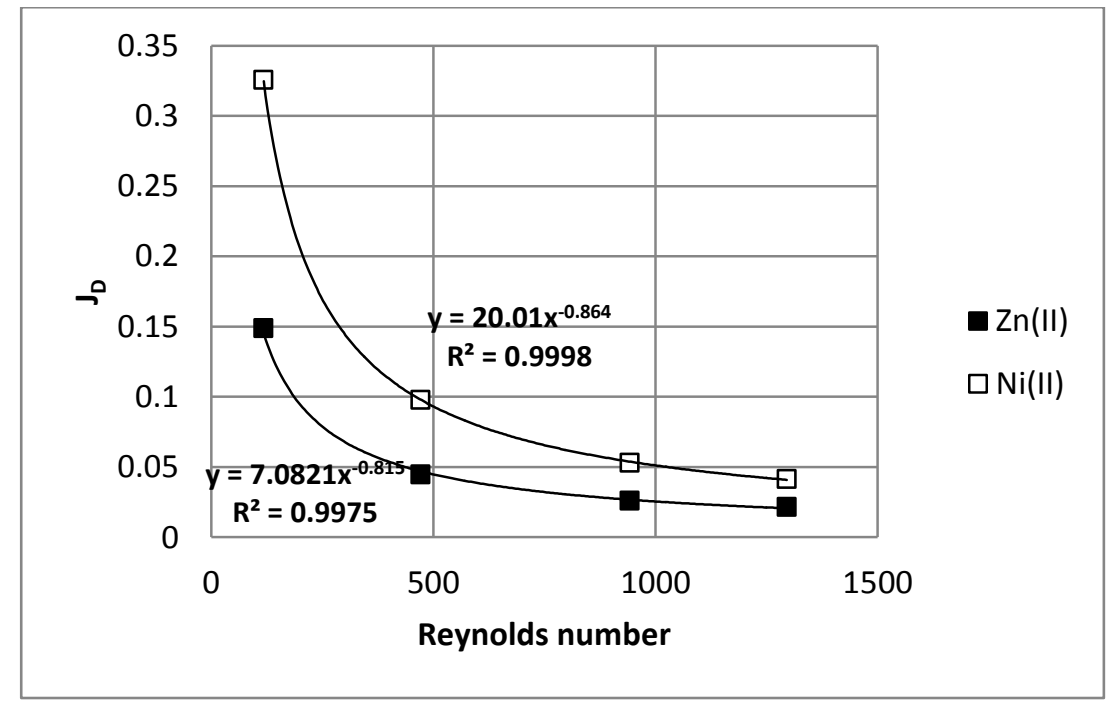

Figure 27: $\mathrm{J}_{\mathrm{D}}$ factor at various Reynolds number for the transfer of $\mathrm{Zn}^{2+}$ and $\mathrm{Ni}^{2+}$ binary in the electro-cell 


\section{Economic evaluation}

In the last three decades due to increasing in environmental awareness and concerns, high number of research was conducted on using living or non-living microorganisms as adsorbents for removal of low concentration metal-bearing wastewater (Modak and Natarajan, 1995). While many researchers consider biosorption as an alternative solution to remove heavy metals at low concentration from wastewater, the process has not been applied in full scaled as yet. This part of study is to evaluate the economic feasibility of this study comparative to chemical precipitation process.

Currently, chemical precipitation is widely used for the removal of metals from industrial wastewater. The metal removal and recovery can be accomplish by addition of appropriate chemicals, followed by conventional solid-liquid removal that could be by sedimentation, flotation, filtration, in extreme cases even by more expensive centrifugation (EPA., 2000). There are certain disadvantages of this type of water treatment, including leaving behind "hazardous sludge" which needs to be safely disposed. This adds to the overall cost of the wastewater treatment (Park et al., 2010). Iron Mountain Mine Shasta County, California, reported that the operational cost (i.e. chemical usage and handling sludge generation) was estimated as \$0.067/L for removal of the heavy metals, practically zinc and nickel at range 0-30 ppm, using chemical precipitation. The average wastewater flow rate of the plant is $230 \mathrm{~L} / \mathrm{min}$ (USEPA Iron Mountain Mine Superfund Site, 2009). Similar cases have been reported at varied wastewater treatment plants that use chemical precipitation, including Leviathan Mine Site Alpine County, California (EPA Hardrock Mining Innovative Technology Case Studies, 2006). 
In this study, the economic evaluation of recovery of $\mathrm{Zn}^{2+}$ and $\mathrm{Ni}^{2+}$ binary from wastewater using integrated biosorption and electro-deposition was performed using best operational conditions in all biosorption, desorption and electro-deposition processes. All economic parameters (e.g. price) used in this evaluation are referred to Canada market in 2009. The cost of wheat straw is $\$ 24$ per ton biomass (Alberta Agriculture and Rural Development, 2009). The cost of each individual processes has been estimated as, $\$ 0.0044, \$ 0.0044$ and $\$ 0.0085$ per liters for biosorption, desorption and electro-deposition, respectively. The total cost of operation is estimated as $\$$ 0.0173 per Liter. Therefore, the recovery of the heavy metals using Integrated Biosorption and Electro-deposition has great advantages from both technical and economical perspectives over the chemical precipitation technology.

It is important to note that despite the relative simplicity and cost-effectiveness of biosorption process, the technology based on it is as yet unproven and for its field success it requires continued research and development effect. Development of such a technology would require filling in a number of gaps in knowledge concerning metal sorption by biomass, such as a better understanding mechanism of metal biosorption. Furthermore, despite the fact that industrial effluents contain several metal ions simultaneously, little attention has been given to sorption of metals from multi-metal solutions. It is essential to realize that industrial effluents can differ from each other a great deal even though the technological processes where they originate may be turning out similar end-products. Therefore, biosorption is still is in its early development stages and further improvements in both performance and cost-effectiveness can be expected (Volesky, 2003; Kotrba et al., 2011). 


\section{Conclusion}

The study presented in this thesis aimed at the development an effective wastewater treatment process from removal and recovery of $\mathrm{Zn}^{2+}$ and $\mathrm{Ni}^{2+}$ binary mixture from wastewater. A central composite face-centered (CCF) method was used to obtain best operational conditions for biosorption of $\mathrm{Zn}^{2+}$ and $\mathrm{Ni}^{2+}$ binary solution in a fixed bed column packed with wheat straw as biosorbent. The effect of bed depths from 0.5 to $2.0 \mathrm{~m}$, liquid flow rates from 0.1 to $0.5 \mathrm{~L} . \mathrm{min}^{-1}$, biosorbent particle sizes of 0.5 to 2 inches and initial concentrations from 10 to $50 \mathrm{mg} \mathrm{\textrm {L } ^ { - 1 }}$ on biosorption performance was investigated. The results showed that the breakthrough service time of the biosorption columns $\left(\mathrm{C}_{\mathrm{b}}=2 \mathrm{mg}-\mathrm{Zn}-\mathrm{Ni} / \mathrm{L}\right)$ increased with increasing bed depth, while decreased with increasing influent concentrations and flow rates, as expected. The best operational conditions were found as follows: a $2 \mathrm{~m}$ bed depth, $10 \mathrm{mg}-\mathrm{Zn}-\mathrm{Ni} / \mathrm{L}$ binary influent concentrations, a $0.1 \mathrm{~L} / \mathrm{min}$ inlet upward flow rate and 0.5 inch length particle size.

The BDST model was applied in this study to predict the breakthrough curves of $\mathrm{Zn}^{2+}$ and $\mathrm{Ni}^{2+}$ binary mixture biosorption in a fixed bed of wheat straw. The BDST provided a good correlation between the bed depth and service time at varied flow rates.

For biomass regeneration, the effect the type of desorbing agent, the concentration and the flow rate on recovery of $\mathrm{Zn}^{2+}$ and $\mathrm{Ni}^{2+}$ binary mixture was investigated. The effect of hydrochloric acid, nitric acid and sulphuric acid as desorbing agents on wheat straw regeneration process at varied concentrations from 0.1 to $0.5 \mathrm{M}$ and flow rate ranging from 0.05 to $0.1 \mathrm{~L} / \mathrm{min}$ was investigated. The results indicated that hydrochloric acid was poor desorbing agents. The best performance was observed at a $\mathrm{H}_{2} \mathrm{SO}_{4}$ concentration of $0.1 \mathrm{M}$ and a flow rate of $0.05 \mathrm{~L} \cdot \mathrm{min}^{-1}$. 
To test the reusability of wheat straw fixed-bed column, a total of five successive biosorption/desorption cycles were performed. The biosorption runs were conducted up to the breakthrough point $\left(\mathrm{C}_{\mathrm{b}}=2 \mathrm{mg}-\mathrm{Zn}-\mathrm{Ni} / \mathrm{L}\right)$. Desorption processes were ceased when no trace of $\mathrm{Zn}^{2+}$ and $\mathrm{Ni}^{2+}$ ions detected in the column effluent. The results showed that wheat straw retained its zinc and nickel uptake capacity in all the five cycles examined.

Lastly, electrode-position was used to recover metals from the concentrated zinc and nickel binary solution from the desorption step. In this study, the impact of the current density (3.75 to $\left.27.50 \mathrm{~mA} / \mathrm{cm}^{2}\right)$ and the electrolyte volumetric flow rate $(0.90$ to $9.88 \mathrm{~L} / \mathrm{min})$ was investigated. The results showed that a normal co-deposition of Ni-Zn at a low current density $\left(3.75 \mathrm{~mA} . \mathrm{cm}^{-2}\right)$ while an anomalous co-deposition at higher current densities. The most suitable operational conditions were determined at the current density of $3.75 \mathrm{~mA} / \mathrm{cm}^{2}$ and the volumetric flow rate of $9.88 \mathrm{~L} / \mathrm{min}$ with an operational time of approximately 60 hours to reduce both metal ion concentrations to below 2 ppm. 


\section{Recommendation}

The following recommendations are made for future studies:

1. As the mechanism of biosorption on wheat straw is complex phenomenon. It would be useful to investigate the structure of wheat straw using different methods, (i.e. Scanning Electron Microscopy (SEM)) to find out the chemical groups on structure;

2. Explore the potential application of wheat straw to wastewater from industrial effluents;

3. Explore spectroscopic techniques (i.e. Atomic Force Microscopy (AFM)) and some industrial standard methods to investigate deposit characteristics of $\mathrm{Zn}-\mathrm{Ni}$ plating and evaluate the feasibility of $\mathrm{Zn}^{2+}$ and $\mathrm{Ni}^{2+}$ binary reuse through electro-plating; 


\section{References}

Abibsi, A., Dennis, J.K., Short, N.R., 1991. The effect of plating variables on zinc-nickel alloy electrodeposition. Trans. Inst. Metal, Finish. 69, 145-148.

Abou-Krisha, M. M., Assaf, F. H., and Toghan, A. A., 2007. Electrodeposition of Zn-Ni alloys from sulfate bath. J. Solid. State. Electrochem. 11, 244-252

Addour, L., Belhocine, D., Bouderis, N., Comeau, Y., Pauss, A. and Mameri, N., 1999. Zinc uptake by Streptomyces rimosus biomass using a packed-bed column. J. Chem. Technol. Biotechnol. 74, 1089-1095

Ahluwalia, S. S. and Goyal, D., 2007. Microbial and plant derived biomass for removal of heavy metals from wastewater. Bioresour. Technol, 98, 2243-2257

Akhtar, N., Iqbal, M., Zafar, S.I. and Iqbal, J, 2008. Biosorption characteristics of unicellular green alga Chlorella sorokiniana immobilized in loofa sponge for removal of $\mathrm{Cr}$ (III). J. Environ. Sci. 20, 231-239

Aksu, Z., Sag, Y. and Kutrrsal, T., 1992. The biosorption of copper (II) by C. vulgaris and Z. ramigera. Environ. Technol. 13, 579-586

Aksu, Z., 1998. Biosorption of heavy metals by microalgae batch and continuous systems. In: Wong, Y-S., Tam, N. F. Y. (Eds), Algae for Wastewater Treatment. Springer-Verlag and Landes Bioscience, Germany, 37-53

Al-Saraj, M., Abdel-Latif, M.S., El-Nahal, I. and Baraka, R., 1999. Bioaccumulation of some hazardous metals by sol-gel entrapped microorganisms. J. Non-Cryst. Solids, 248,137-140

Alam, M., Nadeem, R. and Jilani, M.I., 2012. Pb(II) removal from wastewater using Pomegranate waste biomass. Inter.J.Che.Biochem.Sci., 1, 24-29.

Alberta Agriculture and Rural Development, 2009. What is Straw Worth? - Frequently Asked Questions. Retrieved April 24/2013, Available from http://www1.agric.gov.ab.ca/\$department/deptdocs.nsf/all/faq7514

Antunes, W.A., Luna, A.S., Henriques, C.A. and da Costa, A.C., 2003. An evaluation of copper biosorption by a brown seaweed under optimized conditions. Electron. J. Biotechnol. 6, 174-184

Aqeel Ashraf, M., Wajid, A., Mahmood, K., Jamil Maah, M. and Yusoff, I., 2011. Low cost biosorbent banana peel (Musa sapientum) for the removal of heavy metals. SRE, 6, 4055-4064

Arief, V.O., Trilestari, K., Sunarso, J., Indraswati, N. and Ismadji, S., 2008. Recent Progress on Biosorption of Heavy Metals from Liquids Using Low Cost Biosorbents: Characterization, Biosorption Parameters and Mechanism Studies. Clean Soil Air Water. 36, 937-962 
Ayoob, S. and Gupta, A.K., 2007. Sorptive response profile of an adsorbent in the defluoridation of drinking water. The Chem. Eng. J. 133, 273-281

Bahadir, K.K. and Rauf, M.A., 2008. Response Surface Methodology (RSM) Analysis of Photoinduced Decoloration of Toludine Blue, The. Chem. Eng. J. 136, 25-30

Bai, Y. and Bartkiewicz, B., 2009. Removal of Cadmium from Wastewater Using Ion Exchange Resin Amberjet 1200H Columns. Polish. J. of Environ. Stud. 18, 1191-1195

Bai R, S. and Abraham, T.E., 2001. Biosorption of Cr(VI) from aqueous solution by Rhizopus nigricans, Bioresour. Technol. 79, 73-81

Baig, K.S, Doan, H.D. and Wu, J., 2009. Multicomponent isotherms for biosorption of $\mathrm{Ni}^{2+}$ and $\mathrm{Zn}^{2+}$, Desalination, 249, 429-439

Bajwa, R., Javaid, A. and Manzoor, T., 2009. Ni (II) and Cu (II) Removal by Chemically Treated Biomass of Rhizopus apphizus, Pak. J. Phytopathol. 21, 45-48

Bajat, J.B., Kačarević-Popović, Z., Mišković-Stanković, V.B. and Maksimović, M.D., 2000. Corrosion behavior of epoxy coatings electrodeposited on galvanized steel and steel modified by Zn-Ni alloys. Prog. Org. Coat. 39, 127-135

Baker, R., 2004. Membrane Technology and Applications. John Wiley \& Sons Ltd, England.

Bakkaloglu, I., Butter, T.J., Evison, L.M., Holland, F.S. and Hancockt, I.C., 1998. Screening of various types biomass for removal and recovery of heavy metals $(\mathrm{Zn}, \mathrm{Cu}, \mathrm{Ni}$ ) by biosorption, sedimentation and desorption. Water. Sci. Technol. 38, 269-277

Bedell, G.W. and Darnall, D.W., 1992. Immobilization of nonviable biosorbent algal biomass for the recovery of metal ions, in Biosorption of Heavy Metals, B. Volesky, Editor. CRC Press, Boca Raton, 314-326

Beltowska-Lehman, E., Ozga, P., Swiatek, Z. and Lupi, C., 2002. Electrodeposition of Zn-Ni protective coatings from sulfate-acetate baths. Surf. Coat. Technol. 151-152, 444-448.

Belter, P.A, Cussler, E.L, Hu, W-S., 1988. Bioseparations: Downstream Processing for Biotechnology, John Wiley and Sons

Benballa, M., Nils, L., Sarret, M. and Müller, C., 2000. Zinc-nickel Codeposition in Ammonium baths. Surf.Coat.Technol. 123, 55-61

Benefield, L.D., Judkins, J.F. and Weand, B.L., 1982. Process Chemistry for water and Wastewater Treatment. Prentice-Hall, Inc., New Jersey

Bird, R.B., Stewart, W.E. and Lightfoot, E.N., 2002. Transport Phenomena, second ed., John Wiley \& Sons, Inc., New York 
Blázquez, G., Calero, M., Hernáinz, F., Tenorio, G. and Martín-Lara, M.A., 2010. Batch and Continuous Packed Column Studies of Chromium (III) Biosorption by Olive Stone. Enviro. Prog. Sus. Ene.30, 576-585

Bodnar, M., Hajdu, I., Hartmann, J.F. and Borbely, J., 2008. Toxic Heavy Metal Ions Removal from Waste Water by Membrane Filtration of PGA-based Nanoparticles. Nanotech 2008 Conference Abstract, University of Debrecen, HU

Bohart, G.S., Adams, E.Q., 1920. Some aspects of the behavior of charcoal with respect to chlorine. J. Am. Chem. Soc. 42, 523-529

Box, G.E.P and Draper, N.R., 1987. Empirical Model-building and response surfaces, John Wiley \& Sons, New York.

Brenner, A., 1963. Electrodeposition of Alloys. Principles and Practice, Volume 2. Academic Press, New York

Bret, C.M.A. and Bret, A.M.O., 1993. Electrochemistry Principles, Methods and Applications, Oxford University Press. England

Cadral, J.P.S., 1992. Selective binding of metal ions to Pseudomonas syringae cells. Microbios. $71,47-53$

Chaisuksant, Y., 2003. Biosorption of cadmium (II) and copper (II) by pretreated biomass of marine alga Gracilaria fisheri. Environ. Technol. 24, 1501-1508.

Cossich, E.S., Da silva, E.A., Tavares, C.R.G., Filho, L.C., Ravagnani, T.M.K., 2004. Biosorption of chromium (III) by biomass of seaweed Sargussum sp. in a fixed-bed column. Adsorption, 10, 129-138.

Chen, S., 2004. Electrochemical technologies in wastewater treatment, Sep. Purif. Technol. 38, $11-41$

Cheremisinoff, P.N. and Cheremisinoff, N.P., 1993. Carbon adsorption for pollution control, PTR Prentice Hall, New Jersey

Choi, S.B., Yun, Y.S., 2004. Lead biosorption by waste biomass of Corynebacterium glutamicum generated from lysine fermentation process. Biotechnol. Lett. 26, 331-6

Chu, K.H., 2004. Improved fixed bed models for metal biosorption. The Chem. Eng. J. 97, 233239

Chun-Chiu, L., 2010. Removal and recovery of toxic metal contaminants from process effluents using integrated biosorption and electroplating. Ph.D., Dept. of Applied Biology and Chemical Technology, The Hong Kong Polytechnic University 
Crini, G., 2005. Recent developments in polysaccharide-based materials used as adsorbents in wastewater treatment. Prog. Polym. Sci. 30, 38-70

Crittenden, J.C., Rhodes Trussell, R., Hand, D.W., Howe, K.J., Tchobanoglous, G., 2005. Water Treatment - Principles and Design, 2nd Edition. John Wiley \& Sons, Inc. New York

Crow, D.R., 1998. Principles and Applications of Electrochemistry. Stanley Thornes Ltd., cheltenham

Dąbrowski, A., Hubicki, Z., Podkościelny, P. and Robens, E., 2004. Selective removal of the heavy metal ions from waters and industrial wastewaters by ion-exchange method. Chemosphere. $56,91-106$

Da Costa, A.C.A, Da Mesquita, L.M.S. and Tornovsky, J., 1996. Batch and Continues Heavy Metals Biosorption by brown Seaweed from a Zinc-producing Plant, Minerals. Eng. 9, 811-82

Davis, T.A., Volesky, B. and Vieira, R.H.S.F., 2000. Sargassum seaweed as biosorbent for heavy metals. Wat. Res. 34, 4270-4278.

Dahma, H. and Croll, I.M., 1965. The anomalous codeposition of iron nickel alloys. $J$. Electrochem. Soc. 112, 771-775

Doan, H.D., Wu, J., Boithi, E. and Storrar, M., 2003. Treatment of Wastewater using A Combined Biological and Electrochemical Technique. J. Chem. Technol. Biotechnol. 78, 632-641

Doan, H.D., Lohi, A., Dang, V.B.H., and Dang-Vu, T., 2008. Removal of $\mathrm{Zn}^{2+}$ and $\mathrm{Ni}^{2+}$ by adsorption in a fixed-bed of wheat straw, Process Safety and Environment Protection. 86, 259267

Doan, H.D., and Saidi, M., 2008. Simultaneous removal of metal ions and linear alkylbenzene sulfonate by combined electrochemical and photocatalytic process. J. Hazard. Mater. 158, 557567

Dursun, A.Y. and Aksu, Z., 2000. Biodegradation kinetics of ferrous (II) cyanide complex ions by immobilized Pseudomonas fluorescens in a packed column reactor. Process. Biochem. 35, 615-622

Duruibe, J.O., Ogwuegbu, M.O.C. and Egwurugwu, J.N., 2007. Heavy metal pollution and human biotoxic effects. Int. J. Phys. Sci. 2, 112-118

Eccles, H., 1995. Removal of heavy metals from effluent streams - why select a biological process?. Inter. Biodeter. Biodegra.35, 5-16

Elkhatabi, F., Benballa, M., Sarret, M. and Müller, C., 1999. Dependence of coating characteristics on deposition potential for electrodeposited Zn-Ni alloys. Electrochimica Acta. 44, $1645-1653$ 
El-Sayed, G.O., Dessouki, H.A., and Ibrahim, S.S., 2010. Biosorption of Ni (II) and Cd (II) Ions from Aqueous Solutions onto Rice Straw, Chem. Sci. J.CSJ-9

EPA., 2000. Wastewater technology sheet: chemical precipitation. United State Environmental Protection, Retrieved September 19, 2012, Available from http://water.epa.gov/scitech/wastetech/upload/2002_06_28_mtb_chemical_precipitation.pdf

EPA hardrock Mining Innovative Technology Case Studies, 2006. Leviathan Mine, CompostFree Sulfate-Reducing Bioreactor Treatment of Aspen Seep, U.S. Environmental Protection Agency, Retrieved April 24/2013, Available from http://www.epa.gov/aml/tech/leviathan.pdf

USEPA Iron Mountain Mine Superfund Site, 2009. EPA Accelerating Cleanup Efforts at Iron Mountain Mine Site Supporting Local Economy with Recovery Act Funds. U.S. Environmental Protection Agency, Region 9, San Francisco

Eriksson, L., Johansson, E., Kettaneh-Wold, N., Wikström, C and Wold, S., 1999-2008. Design of Experiments Principle and Applications, Third revised and enlarged edition, Umetrics Academy

Esposito, A., Pagnanelli, F., Vegliò, F., 2002. pH-related equilibrium models for biosorption in single metal systems. Chem. Eng. Sci. 57, 307-313.

Fagundes-Klen, M.R., Veit, M.T., Borba, C.E., Bergamasco, R., de Lima Vaz, L.G. and da Silva, E.A. 2010. Copper Biosorption by Biomass of Marine Alga: Study of Equilibrium and Kinetics in Batch System and Adsorption/Desorption Cycles in Fixed Bed Column. Water. Air. Soil. Pollut. 213, 15-26

Farooq, U., Kozinski, J.A., Khan, M.A. and Athar, M., 2010. Biosorption of heavy metal ions using wheat based biosorbents - A review of the recent literature. Biores. Technol. 101, 50435053

Fedrizzi, L., Fratesi, R., Lunazzi, G. and Roventi, G., 1992. Field and laboratory corrosion tests on zinc-nickel alloy coatings, Surf. Coat. Technol. 53, 171-176

Fourest, E. and Roux, J.C., 1992. Heavy metal biosorption by fungal mycelia by-products: mechanism and influence of pH. Appl. Microbiol. Biotechnol, 37, 399-403

Fraile, A., Penche, S., González, F., Blázquez, M.L., Muǹoz. and Ballester, A., 2005. Biosorption of copper, zinc, cadmium and nickel byChlorella vulgaris. Chemistry and Ecology. 21, 61-75

Frišták,V., Remenárová, L. and Lesný, J., 2012. Response Surface Methodology as Optimization Tool in the study of Competitive effect of $\mathrm{Ca}^{2+}$ and $\mathrm{Mg}^{2+}$ ions in Sorption process of $\mathrm{Co}^{2+}$ by dried activated sludge. The J. Microbiol. Biotechnol. Food. Sci, 1235-1249 
Ghasemi, M., Keshtkar, A.R., Dabbagh, R. and Safdari, S.J, 2011. Biosorption of uranium(VI) from aqueous solutions by Ca-pretreated Cystoseira indica alga: Breakthrough curves studies and modeling. J. Hazard. Mater. 15, 141-149

Girdhar, P., 2008. Performance evaluation of Pumps and Compressors. Technology and Engineering, Lulu.com

Göksungur, Y., Üren, S., and Güvenc, U., 2005. Biosorption of cadmium and lead ions by ethanol treated waste baker's yeast biomass, Bioresour. Technol. 96, 103-109

Goyal, H., Jain, S.C. and Banerjee, U.C., 2003. Comparative studies on the microbial adsorption of heavy metals. Adv. Environ. Res. 7, 311-319

Grimm, A., Zanzi, R., Björnborn, E., Cukierman, A.L., 2008. Comparison of different types of biomasses for copper biosorption. Bioresour. Technol. 99, 2559-2565

Han, R., Wang, Y, Han, P., Shi, J., Yang, J., Lu, Y, 2006a. Removal of methylene blue from aqueous solution by chaff in batch mode. J. Hazard. Mater. 137, 550-557

Han, R., Zhang, J., Zou, W., Xiao, H., Shi, J., and Liu, H., 2006b. Biosorption of copper (II) and lead (II) from aqueous solution by chaff in a fixed-bed column. J. Hazard. Mater. 133, 262-268

Han, M.H., Yun, Y-S., 2007. Mechanistic understanding and performance enhancement of biosorption of reactive dyestuffs by the waste biomass generated from amino acid fermentation process. Biochem. Eng. J. 36, 2-7.

Han, R., Ding, D., Xu, Y., Zou, W., Wang, Y., Li, Y. and Zou, L., 2008. Use of rice husk for the adsorption of congo red from aqueous solution in column mode. Bioresour. Technol. 99, 29382946

Hammaini, A., González, F., Ballester, A., Blázquez, M.L. and Muńoz, J.A., 2007. Biosorption of heavy metals by activated sludge and their desorption characteristics. $J$. Environ. Manage. 84, 419-426.

Hanif, M.A., Nadeem, R., Bhatti, H.N., Ahmad, N. R. and Ansari, T.M., 2007. Ni (II) biosorption by Cassia fistula (Golden Shower) biomass. J. Hazard. Mater. 139, 345-355

Hasan, S.H., Srivastava, P., and Talat, M., 2010. Biosorption of lead using immobilized Aeromonas hydrophila biomass in up flow column system: Factorial design for process optimization. J. Hazard. Mater. 177, 312-322

Hassler, J.W., 1974. Purification with activated Carbon. Chemical Publishing Company, New York 
Hatzikioseyian, A., Mavituna, F. and Tsezos, M., 1999. Modelling of fixed bed biosorption columns in continuous metal ion removal processes. The case of single solute local equilibrium. Process Metallurgy. 9, 429-448

Higashi, K., Fukushima, H., Urakawa, T., Adaniya, T. and Matsuko, K., 1981. Mechanism of the Electrodeposition of Zinc Alloys Containing a Small Amount of Cobalt. J. Electrochem. Soc.128, 2081-2085

Hill, John.W. and Petrucci, Ralph.H., 1996. General chemistry. New Jersey, Prentice Hall

Ho, Y.S., 2003. Removal of copper ions from aqueous solution by tree fern. Wat. Res. 37, 23232330

Huang, C. and Huang, C.P., 1996. Application of Aspergillus oryzae and Rhizopus oryzae for Cu (II) removal. Wat. Res. 30, 1985-1990

Huang, C.P., Westman, D., Quirk, K. and Huang, J.P., 1988. The removal Cadmium (II) from Dilute Solutions by Fungal Adsorbent. Wat. Sci. Technol. 20, 369-376

Hutchins, R. A., 1973. New simplified design of activated carbon systems. Am. J. Chem. Eng., $80,133-138$.

Incharoensakdi, A. and Kitjaharn, P., 2002. Zinc biosorption from Aqueous Solution by a Halotolerant Cyanobacterium Aphanothece halophytica, Curr Microbiol. 45, 261-264

Judd. S., 2006. The MBR Book: Principles and Applications of Membrane Bioreactors in Water and Wastewater Treatment, Elsevier, Oxford

Jusoh, A., Shiung, L.S., Ali, N., Noor, M.J.M.M., 2007. A simulation study of the removal efficiency of granular activated carbon on cadmium and lead. Desalination, 206, 9-16

Jüttner, K., Galla, U. and Schmieder H., 2000. Electrochemical approaches to environmental problems in the process industry, Electrochimica Acta, 45, 2575-2594

Kaewsarn, P., 2000. Single and multi-component biosorption of heavy metal ions by biosorption from marine Alga Durvillaea potatorum, Ph.D. Diss., Environmental Engineering, Griffith University, Queensland.

Kalavathy, M.H., Karthikeyan, T., Rajgopal, S. and Miranda, L.R., 2005. Kinetic and isotherm studies of $\mathrm{Cu}$ (II) adsorption onto $\mathrm{H}_{3} \mathrm{PO}_{4}$-acrtivated rubber wood sawdust, J. Colloid. Interface. Sci. 292, 354-362

Kapoor, A. and Viraraghavan, T., 1997. Heavy-metal biosorption sites in Aspergillus niger. Biores. Technol. 61, 3, 221-227

Ko. D. C. K., Porter, J. F., McKay, G., 2000. Optimized correlations for the fixed-bed adsorption of metal ions on bone char, Chem. Eng. Sci. 55, 5819-5829 
Kotrba, P., Mackva, M., Macek, T., 2011. Microbial Biosorption of Metals. Springer, New York

Kuczajowska-Zadrożna, M., Klimiul, E. and Wojnowsja-Baryla, I., 2004. Cyclical Cadmium Adsorption and Desorption by Activated Sludge Immobilized on Alginate Carriers. Pol. J. Environ. Stud. 13, 161-169

Kumar, U. and Bandyopadhyay, M., 2006. Fixed bed column study for Cd (II) removal from wastewater using treated rice husk, J. Hazard. Mater. 129, 253-259

Kumar, R., Singh, R., Kumar, N., Bishnoi, K. and Bishnoi, N.R., 2009. Response surface methodology approach for optimization of biosorption process for removal of $\mathrm{Cr}$ (VI), $\mathrm{Ni}$ (II) and Zn (II) ions by immobilized bacterial biomass sp. Bacillus brevis. The Chem. Eng. J. 146, 401407

Kundu, S. and Gupta, A.K., 2007. As (III) removal from aqueous medium in fixed bed using iron oxide-coated cement (IOCC): Experimental and modeling studies. The Chem. Eng. J. 129, 123131

Kuyucak, N. and Volesky, B., 1988. Biosorbent for Recovery of metals from Industrial Solutions. Biothechnology Letters, 10, 137-142

Lawther, J.M., Sun, R., Banks, B., 1995. Extraction, fractionation and characterization of structural polysaccharides from wheat straw. J. Agric. Food Chem. 43, 667-675.

Lee Kang, O., Ramli, N. and Ahmad, M., 2012. Cadmium (II) Biosorption onto Seaweed (Kappaphycus alvarezii and Eucheuma ddenticulatum) Waste Biomass: Equilibrium and Mechanism Studies. Middle-East. J. Sci. Res. 11, 867-872

Lehmberg, C.E., Lewis, D.B. and Marshall, G.W., 2005. Composition and structure of thin electrodeposited zinc-nickel coatings. Surf. Coat. Technol.192, 269- 277

Li, Q., Wu, S., Liu, G., Lina, X., Deng, D., Sun, Y. and Hu, Y. Huang. 2004. Simultaneous biosorption of cadmium(II) and lead(II) ions by pretreated biomass of Phanerochaete chrysosporium. Sep. Purif. Technol. 34, 135-142

Lodeiro, P., Cordero, B., Barriada, J.L., Herrero, B.R., de Vicente M.E.S, 2006. Biosorption of cadmium by biomass of brown marine macroalgae. Bioresour. Technol. 96, 1796-1803

Loukidou, M.X., Karapantsios, T.D., Zouboulis, A.I., and Matis, K.A., 2004. Diffusion kinetic study of cadmium (II) biosorption by Aeromonas cavia. J. Chem. Technol. Biotechnol. 79, 711719

Lovley, Derek R., 2000. Environmental Microbe-Metal Interactions. ASM Press, U.S.A

Low, K.S., Lee, C.K. and $\mathrm{Ng}$, A.Y., 1999. Column studies on the sorption of $\mathrm{Cr}(\mathrm{VI})$ using quaternized rice hulls. Bioresour. Technol. 68, 205-208 
Low, K.S., Lee, C.K., Liew, S.C., 2000. Sorption of cadmium and lead from aqueous solutions by spent grain. Process. Biochem. 36, 59-64.

Mack, C., Burgess, J. E., and Duncan, J. R. 2004. Membrane bioreactors for metal recovery from wastewater: A review. Water SA. 30.

Maheswari, S. Murugesan, A.G., 2011. Biosorption of As(III) ions from aqueous solution using dry, heat-treated and $\mathrm{NaOH}$-treated Aspergillus nidulans, Environ. Technol. 32, 211-219

Prakasham, R.S., Merrin, J.S., Sheela, R., Saswathi, N. and Ramakrishna, S.V., 1998. Biosorption of chromium VI by using free and immobilized Rhizopus arrhizus, Ind. J. Exp. Biol. $104,421-427$

Melas, V.B., 2006. Functional Approach to Optimal Experimental Design. Springer, New York

Modak, J. M. and Natarajan, K. A., 1995. Biosorption of metals using nonliving biomass-a review. Miner. Metall. Proc. 12, 189-196

Montgomery, D.C., 2005, Design and analysis of experiments. 6th ed. John Wiley \& Sons, Inc., USA

Muhamad, H., Doan, H. and Lohi, A., 2009. Biosorption of $\mathrm{Cd}^{2+}$ and $\mathrm{Cu}^{2+}$ onto wheat straw using batch and continuous fixed-bed column systems, The Chem. Eng. J. 158, 369-377

Muraleedharan, T.R. and Venkobachar, C., 1990. Mechanism of biosorption of copper (II) by Ganoderma lucidium. Biotechnol. Bioeng. 35, 320-325

Myers, R.H. and Montgomery, D.C., 2002. Response Surface Methodology Process and Product Optimization Using Designed Experiments, 2nd ed., John Wiley, New York

Oliveira, F.D., Soares, A.C., Freitas, O.M. and Figueiredo, S.A., 2010. Copper, Nickel and Zinc remocal by Peanut Hulls: Batch and Column studies in Mono, Tri-component systems and with Real effluent. Global Nest Journal, 12, 206-214

Önal, S., Baysal, S.H. and Ozdemir, G., 2007. Studies on the applicability of alginate-entrapped Chryseomonas luteola TEM 05 for heavy metal biosorption. J. Hazard. Mater. 146, 417-420

Orhan, G., Alson, C., Bombach, H. and Stelter, M., 2002. Nickel recovery from the risen water of plating baths, Metallurgical and Materials Eng. 65, 1-8

Orion Fittings, 2013. Friction Loss in Fittings. Retrieved April 01/2013, available from http://media.wattswater.com/Orion-HP-FrictionLoss.pdf

Osman, H.E., Badwy, R.K. and Ahmad, H.F., 2010. Usage of Some Agricultural By-products in the Removal of Some Heavy Metals from Industrial Wastewater. Journal of Phytology. 2, 51-62 
Özer, A. and Özer, D., 2003. Comparative study of the biosorption of $\mathrm{Pb}(\mathrm{II}), \mathrm{Ni}(\mathrm{II})$ and $\mathrm{Cr}(\mathrm{VI})$ ions onto S. cerevisiae: determination of biosorption heats. J. Hazard. Mater, 100, 219-229

Oztürk, A., 2007. Removal of Nickel from aqueous solution by the bacteria Bacillus thuringiensis, J. Hazard. Mater.147, 518-523

Pagnanelli, F., Esposito, A., Toro, L. and Vegliò, F., 2003. Metal speciation and pH effect on Pb, $\mathrm{Cu}, \mathrm{Zn}$ and $\mathrm{Cd}$ biosorption onto Sphaerotilus natans: Langmuir-type empirical model, Wat. Res. $37,627-633$

Park, D., Yun, Y.S. and Park, J.M., 2010. The Past, Present, and Future Trends of Biosorption. Biotechnology and Bioprocess Engineering. 15, 86-102

Paunovic, M. and Schlesinger, M., 1998. Fundamentals of electrochemical deposition, $2^{\text {nd }}$ Edition, John Wiley \& Sons, Inc., New York

Pradhan, P., Singh, S. and Chand Rai, L., 2007. Characterization of various functional groups present in the capsule of Microcystis and study of their role in biosorption of $\mathrm{Fe}, \mathrm{Ni}$ and $\mathrm{Cr}$. Bioresour. Technol. 98, 595-601

Preetha, B. and Viruthagiri, T., 2007. Batch and Contiuous biosorption of chromium (VI) by Rhizopus arrhizus. Sep. Purif. Technol.57, 126-133

Rao, C.R.N., Lsyengar, L. and Venkobachar, C., 1993. Sorption of copper (II) from aqueous phase by waste biomass, J. Environ. Eng. 199, 369-377

Rengaraj, S., Joo, C.K., Kim, Y.H. and Yi, J.H., 2003. Kinetics of removal of chromium from water and electronic process wastewater by ion exchange resins: $1200 \mathrm{H}, 1500 \mathrm{H}$, and IRN97H, $J$. Hazard. Mater. 102, 257-275

Roventi, G., Fratesi, R., Della Guardia, R.A. and Barucca, G., 2000. Normal and anomalous codeposition of Zn-Ni alloys from chloride bath, Journal of Applied Electrochemistry. 30, 173179

Saeed, A. and Iqbal, M., 2003. Bioremoval of cadmium from aqueous solution by blackgram husk (Cicer arientinum). Wat. Res. 37, 3472-3480

Saeed, A., Akhter, M.W, Iqbal, M., 2005a. Removal and recovery of heavy metals from aqueous solution using papaya wood as a new biosorbent. Sep. Purif. Technol. 45, 25-31

Saeed, A., Muhammed, I. and Akhtar, M.W., 2005b. Removal and recovery of lead(II) from single and multimetal $(\mathrm{Cd}, \mathrm{Cu}, \mathrm{Ni}, \mathrm{Zn})$ solutions by crop milling waste (black gram husk). $J$. Hazard. Mater. 117, 65-73

Sağ, Y., Akçael, B. and Kutsal, T., 2002. Ternary biosorption equilibria of chromium(VI), copper(II), and cadmium(II) on Rhizopus arrhizus. Separation Sci. Technol. 37, 279-309 
Saha, P.D.,Chakraborty, S. and Chowdhur, S., 2012. Batch and continuous (fixed-bed column) biosorption of crystal violet by Artocarpus heterophyllus (jackfruit) leaf powder. Colloids and Surfaces B: Biointerfaces. 92, 262-270

Sang, Y., Li, F., Gu, Q. Liang, C. and Chen, J., 2008. Heavy metal contaminated groundwater treatment by a novel nanofiber membrane. Desalination. 223,349-360

Say, R., Yilmaz, N., Denizli, A., 2003. Biosorption of cadmium, lead, mercury, and arsenic ions by the fungus Penicillium purpurogenum. Sep. Sci. Technol. 38, 2039-2053

Schneider, I.A.H., Rubio, J. and Smith, R.W., 2001. Biosorption of metals onto plant biomass: exchange adsorption or surface precipitation?. Int. J. Miner. Process. 62. 111-120

Selatnia, A., Boukazoula, A, Kechid, N., Boukhti, M.Z. and Chergui, A., 2004. Biosorption of $\mathrm{Fe}^{3+}$ from aqueous solution by a bacterial dead Streptomyces rimosus biomass, Proc. Biochem. $39,1643-1651$

Sengil, İ.A. and Özacar, Mahmut., 2009. Competitive biosorption of $\mathrm{Pb}^{2+}, \mathrm{Cu}^{2+}$ and $\mathrm{Zn}^{2+}$ ions from aqueous solutions onto valonia tannin resin. J. Hazard. Mater. 166, 1488-1494.

Sheela, G., Pushpavanam, M. and Pushpavanam, S., 2002. Zinc-nickel alloy electrodeposits for water electrolysis, Int. J. Hydrogen. Energ. 27, 627-633

Sheng, P.X., Ting, Y-P., Chen J.P. and Hong, L., 2004. Sorption of lead, copper, cadmium, zinc, and nickel by marine algal biomass: characterization of biosorptive capacity and investigation of mechanisms. Journal of Colloid and Interface Science. 275, 131-141

Simonsson, D., 1984. A flow-by packed bed electrode for removal of metal ions from wastewater. Journal of applied Electrochemistry. 14, 595-604

Skowroński, T., Pirszel, J. and Pawlik-Skowrońska, B., 2001. Heavy metal removal by the waste biomass of Penicillium chrysogenum. Water Qual. Res. J. Canada. 36, 793-803

Slejko, F.L., 1985. Adsorption technology: A Step-by-Step Approach to Process Evolution and Application, Marcel Dekker Inc., New York, USA

Srisuwan, G. and Thongchai, P., 2004. Removal of Heavy Metals from Electroplating Wastewater by Membrane. J. Sci. Technol. 24, 965- 976.

Srivastava, S. and Goyal, P. 2010. Biosorption: Application Strategies, in Novel Biomaterials decontamination of Toxic Metals from Wastewater, R. Allan, U. Förstner, and W. Salomons, eds., Spring, London

Stirk, W.A. and Staden, J. van, 2002. Desorption of Cadmium and the Reuse of Brown Seaweed Derived Products as Biosorbents. Botanica Marina. 45, 9-16

Suh, J.H. and Kim, D.S., 2000. Effects of $\mathrm{Hg}^{2+}$ and cell conditions on $\mathrm{Pb}^{2+}$ accumulation by 
Sacharomyces cerevisiae. Bioprocess. Eng. 23, 327-329

Tan, T. and Cheng, P., 2003. Biosorption of metal ions with Penicillium chrysogenum, Appl. Biochem. Biotechnol.104, 119-128

Tan, G. and Xiao, D., 2009. Adsorption of cadmium ion from aqueous solution by ground wheat stems. J. Hazard. Mater. 164, 1359-1363

Taty-Costodes, V.C., Fauduet, H., Porte, C., Delacroix, A., 2003. Removal of Cd(II) and Pb(II) ions from aqueous solutions by adsorption onto sawdust of Pinus sylvestris. J. Hazard. Mater. B, $105,121-142$.

Texier, A.C., Andres, Y., Faur-Brasquet, C. and Le Cloires, P., 2002. Fixed-bed study for lanthanide ( $\mathrm{La}, \mathrm{Eu}, \mathrm{yb}$ ) ions removal from aqueous solutions by immobilized pseudomonas aeruginosa: experimental data and modelization, Chemosphere, 47, 333-342

Tien, C., 1994. Adsorption Calculations and Modeling. Butteworth, Boston, MA

Tiwari, D., Kim, H-U and Lee, S-M, 2007. Removal behavior of sericite for $\mathrm{Cu}(\mathrm{II})$ and $\mathrm{Pb}$ (II) from aqueous solutions: Batch and column studies. Sep. Purif. Technol. 57, 11-16

Toronto's Sewers Bylaw, 2010. Toronto Municipal Code Sewers, Chapter 681, City of Toronto: Toronto Water, 14, Available at http://www.toronto.ca/legdocs/municode/1184_681.pdf

Toronto Hydro, 2012. Electricity rates and charges. Retrieved April, 29/2013, available from http://www.torontohydro.com/sites/electricsystem/residential/yourbilloverview/Pages/Electricity Rates.aspx

Treybal, R.E., 1987. Mass-Transfer Operations, third ed., McGraw-Hill, Inc., New York

Tsezos, M. and Volesky, B., 1982a. The Mechanism of Uranium Biosorption by Rhizopus arrhizus, Biotechnol. Bioeng. 24, 385-401

Tsezos, M. and Volesky, B., 1982b. The Mechanism of Thorium Biosorption by Rhizopus arrhizus, Biotechnol. Bioeng. 24, 955-969

U.S. Environmental Protection Agency (EPA), 2012. Target Analyte Metals (Heavy Metals) and Cyanide. Retrieved March 19, 2013, from http://www.epa.gov/reg3hwmd/bflr/regional/analytical/metals.htm

Uzun, I. and Güzel, F., 2000. Adsorption of Some Heavy Metal Ions from Aqueous Solution by Activated Carbon and Comparison of Percent Adsorption Results of Activated Carbon with those of Some Other Adsorbents, Turk. J. Chem. 24, 291- 297

Valdman, E., Erijman, L., Pessoa, F.L.P. and Leite, S.G.F., 2001. Continuous biosorption of $\mathrm{Cu}$ and $\mathrm{Zn}$ by immobilized waste biomass Sargassum sp. Process. Biochem. 36, 869-873 
Van Reis, R. and Zydney, A. 2007. Bioprocess membrane technology. J. Mem. Sci. 297, 16-50

Vassilis, I.J., 2010. Ion exchange and adsorption fixed bed operations for wastewater treatmentPart I: modeling fundamentals and hydraulics analysis. J.Eng.Stu.Res. 16

Veglio, F., Beolchini, F., 1997. Removal of metals by biosorption: a review. Hydrometallurgy. 44, 301-316.

Vieira, R.H. and Volesky, B., 2000. Biosorption: a solution to pollution. Int. Microbiol. 3, 17-24

Vijayaraghavan, K., Jegan, J., Palanivelu, K. and Velan, M., 2005a. Biosorption of copper, cobalt and nickel by marine green alga Ulva reticulata in a packed column, Chemosphere, 60, 419-426

Vijayaraghavan, K., Jegan, J., Palanivelu, K. and Velan, M., 2005b. Biosorption of cobalt (II) and nickel(II) by seaweeds: batch and column studies, Sep. Purif. Technol. 44, 53-59

Vijayaraghavan, K. and Prabu, D., 2006. Potential of Sargassum wightii biomass for copper (II) removal from aqueous solutions: Application of different mathematical models to batch and continuous biosorption data, . J. Hazard. Mater. 137, 558-564

Vijayaraghavan, K. and Yun, Y.S., 2008. Bacterial biosorbents and biosorption, Biotechnol. Advan. 26, 266-291

Volesky, B., 1994. Advances in biosorption of metals: Selection of biomass types, FEMS Microbiol Rev.14, 291-302

Volesky, B. and Holan, Z.R., 1995. Biosorption of heavy metals. Biotechnol. Prog. 11, 235-250

Volesky. B., 2003. Sorption and Biosorption. BV Sorbex, Inc., St. Lambert, Québec, Canada

VWR, 2013 a. Sulfuric Acid, Solution. 10N. BDH. Retrieved April 01/2013, available from https://ca.vwr.com/store/catalog/product.jsp?catalog_number=CABDH3259-1

VWR, 2013 b. EMSURE® Zinc sulfate heptahydrate for analysis. EMD Millipore. Retrieved April 01/2013, available from https://ca.vwr.com/store/catalog/product.jsp?catalog_number=CA1.08883.1000

VWR, 2013 c. Nickel (II) sulfate ACS. Alfa Aesar. Retrieved April 01/2013, available from https://ca.vwr.com/store/catalog/product.jsp?catalog_number=CAAA36336-A4

VWR, 2013 d. Potassium Chloride ACS Grade. Amresco. Retrieved April 01/2013, available from https://ca.vwr.com/store/catalog/product.jsp?catalog_number=CA97061-564

VWR, 2013 e. Potassium Hydroxide, Solution. 1.0N. BDH. Retrieved April 01/2013, available from https://ca.vwr.com/store/catalog/product.jsp?catalog_number=CABDH3212-1 
Wan Ngah, W.S. and Hanafiah, M.A.K.M., 2008. Removal of heavy metal ions from wastewater by chemically modified plant wastes as adsorbents: A review. Biores. Technol.99, 3935-3948

Wang, W.S., Qin, Y. and Li, Z.F., 2006. Biosorption of Zinc from Aqueous Solutions by Rice Bran: Kinetics and Equilibrium Studies, Separation Sci. Technol. 41, 747-756

Wang, L.K., Hung, Y.T. and Shammas, N.K., 2007. Advanced Physicochemical Treatment Technologies, Volume 5, Humana Press

Wang, L.K., Pereiram, N.C. and Hung Y.T., 2010. Handbook of Environmental Engineering: Environmental Bioengineering. Springer

Water Treatment Solutions Lenntech, 2011a. Lead, Retrieved September, 22, 2012, available from http://www.lenntech.com/periodic/elements/pb.htm

Water Treatment Solutions Lenntech, 2011b. Mercury, Retrieved September, 22, 2012, available from http://www.lenntech.com/periodic/elements/hg.htm

Water Treatment Solutions Lenntech, 2011c. Cadmium, Retrieved September, 22, 2012, available from http://www.lenntech.com/periodic/elements/cd.htm

Water Treatment Solutions Lenntech, 2011d. Chromium, Retrieved September, 22, 2012, available from http://www.lenntech.com/periodic/elements/cr.htm

Water Treatment Solutions Lenntech, 2011e. Zinc, Retrieved September, 22, 2012, available from http://www.lenntech.com/periodic/elements/zn.htm

Water Treatment Solutions Lenntech, 2011f. Nickel, Retrieved September, 22, 2012, available from http://www.lenntech.com/periodic/elements/ni.htm

$\mathrm{Wu}$, J. and $\mathrm{Yu}, \mathrm{H} . \mathrm{Q}$., 2008. Biosorption of 2,4-dichlorophenol from aqueous solutions by immobilized Phanerochaete chrysosporium biomass in a fixed-bed column. The Chem. Eng. J. $138,128-135$

Yakubu, N.A., Dudeney, A.W.L., 1986. Biosorption of uranium with Aspergillus niger. In: Eccles, H.H, Hunt, S., (eds). Immobilisation of ions by biosorption. Ellis Harwood Ltd., Chichester.

Yan, G. Viraraghavan. T., 2001. Heavy metal removal in a biosorption column by immobilized M. rouxii biomass. Bioresou. Technol. 78, 243-249

Zeinali, F., Ghoreyshi, A.A. and Najafpour, G.D., 2010. Adsorption of Dichloromethane from Aqueous Phase Using Granular Activated Carbon: Isotherm and Breakthrough Curve Measurements. Middle-East. J. Sci. Res. 5, 191-198 
Zhang, L., Zhao, L., Yu, Y. and Chen, CH., 1998. Removal of lead from aqueous solution by non-living Rhizopus nigricans. Wat. Res.32, 1437

Zhao, M. and Duncan, J.R., 1998. Bed-depth-service-time analysis on column removal of $\mathrm{Zn}^{2+}$ using Azolla filiculoides, Biotechnology Letters. 20, 37-39.

Zhou, J.L. and Kiff, R.J., 1991. The uptake of copper from aqueous solution by immobilized fungal biomass. J. Chem. Technol. Biotechnol. 52, 317-330

Zhu, C., Luan, Z., Wang, Y. and Shan, X., 2007. Removal of cadmium from aqueous solutions by adsorption on granular red mud (GRM). Sep. Purif. Technol.57, 161-169

Ziagova, M., Dimitriadis, G., Aslanidou, D., Papaioannou, X., Tzannetaki, TE., LiakopoulouKyriakiakides, M., 2007. Comparative study of Cd(II) and Cr(VI) biosorption on Pseudomonnas sp and Pseudomonas sp., in single and binary mixtures. Biores Technol. 98, 2859-2865

Zulfadhly, Z., Mashitah, M.D. and Bhatia, S., 2001. Heavy metals removal in fixed-bed column by the macro fungus Pycnoporus sanguineus. Environ. Pollu.112, 463-470 


\section{Appendix A: Biosorption studies}

\section{A-1. Effect of biosorbent particle size}

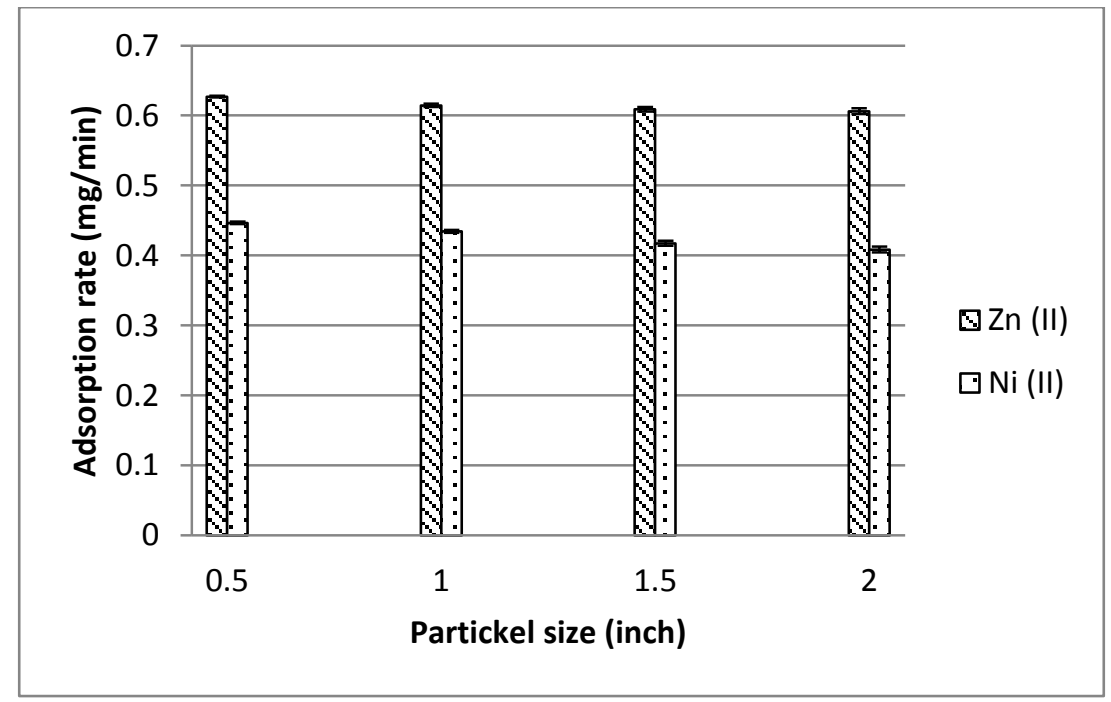

Figure A-1: Effect of particle size on biosorption of binary solution $\left(\mathrm{Zn}^{2+}\right.$ and $\left.\mathrm{Ni}^{2+}\right)$ in fixed-bed at bed depth $=0.5 \mathrm{~m}$; volumetric flow rate $=0.1 \mathrm{~L} / \mathrm{min}$; initial concentration $\left[\mathrm{Zn}^{2+}\right]_{0}=\left[\mathrm{Ni}^{2+}\right]_{0}=10 \mathrm{ppm}$ (60 minutes operation time)

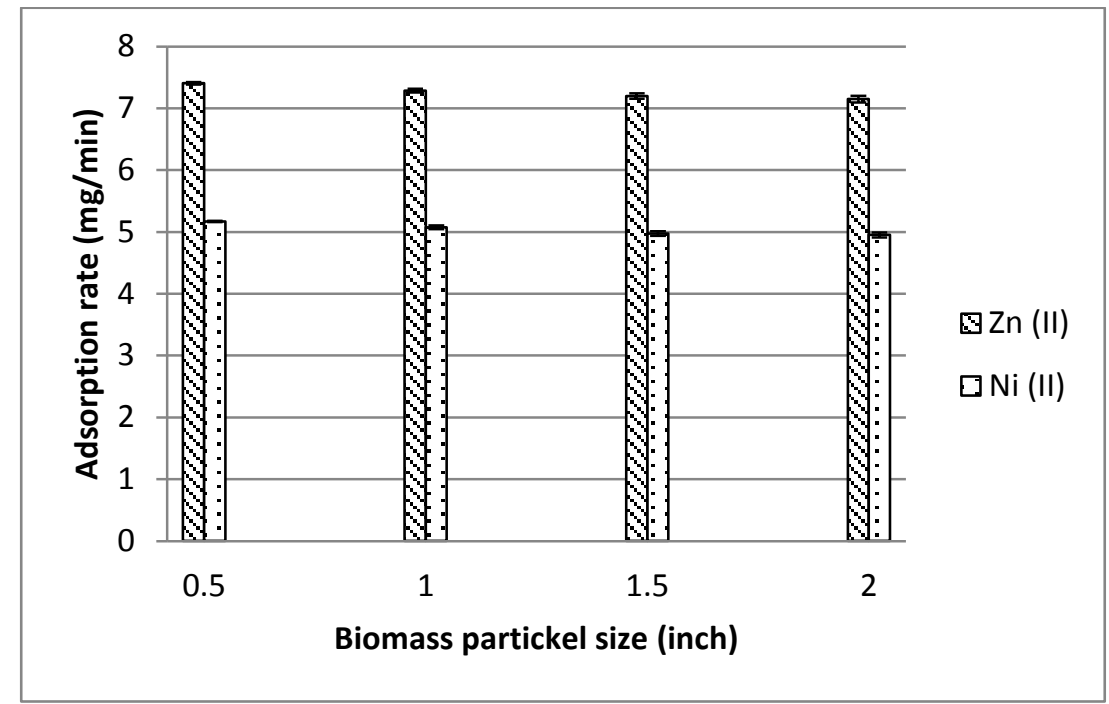

Figure A-2: Effect of particle size on biosorption of binary solution $\left(\mathrm{Zn}^{2+}\right.$ and $\left.\mathrm{Ni}^{2+}\right)$ in fixed-bed at bed depth $=1.25 \mathrm{~m}$; volumetric flow rate $=0.3 \mathrm{~L} / \mathrm{min}$; initial concentration $\left[\mathrm{Zn}^{2+}\right]_{0}=\left[\mathrm{Ni}^{2+}\right]_{0}=30 \mathrm{ppm}$ (60 minutes operation time) 


\section{A-2. Standard deviation calculation}

The calculation of the standard deviation for zinc and nickel binary mixture (Table 11)

$$
\text { Average Deviation }=\sqrt{\frac{1}{N} \sum_{1}^{N}\left(\bar{x}-x_{i}\right)^{2}}
$$

Sample calculation of standard deviation of zinc, based on experimental numbers 15-20 from Table 11:

Average of data Points: $\frac{18.2+18.3+18.4+18.5+18.4+18.3}{6}=18.35$

Average Deviation

$=\sqrt{\frac{1}{6} \sum(18.35-18.2)^{2}+(18.35-18.3)^{2}+(18.35-18.4)^{2}+(18.35-18.5)^{2}+(18.35-18.4)^{2}+(18.35-18.3)^{2}}$

Average Deviation of zinc ion $= \pm 0.09$

Standard deviation of nickel:

Average of data Points: $\frac{7.5+7.5+7.4+7.3+7.5+7.3}{6}=7.42$

Average Deviation

$=\sqrt{\frac{1}{6} \sum(7.42-7.5)^{2}+(7.42-7.5)^{2}+(7.42-7.4)^{2}+(7.42-7.3)^{2}+(7.42-7.5)^{2}+(7.42-7.3)^{2}}$

Average Deviation of nickel ion $= \pm 0.09$ 


\section{A-3. The bed depth service time calculation}

Bed depth service time (BDST) equation:

$t=\frac{N_{o}}{C_{o} v} Z-\frac{1}{C_{o} K} \operatorname{Ln}\left(\frac{C_{o}}{C_{b}}-1\right)$

By using the equation above, which it is represented by a straight line as;

- $\quad$ Slope $=\frac{N_{O}}{C_{o} v}$

- $\quad$ Intercept $=-\frac{1}{C_{o} K} \operatorname{Ln}\left(\frac{C_{o}}{C_{b}}-1\right)$

According to Figure $11-\mathrm{A}$ at $0.1 \mathrm{~L} / \mathrm{min}$ for $\mathrm{Zn}^{2+}$ ions:

$y=46.572 x-3.725$

- $\quad$ Slope $=46.572$

- $\quad$ Intercept $=3.725$

Equilibrium sorption capacity of bed (mg/L)

$N_{o}=46.572 \frac{\mathrm{min}}{\mathrm{m}} * 0.049 \frac{\mathrm{m}}{\mathrm{min}} * 10 \mathrm{mg} / \mathrm{L}$

$N_{o}=22.8 \mathrm{mg} / \mathrm{L}$

\section{$\underline{\text { Kinetic rate parameter (L/mg.min) }}$}

$\frac{1}{\left(10 \frac{m g}{L}\right) * k} \operatorname{Ln}\left[\frac{\left(10 \frac{m g}{L}\right)}{\left(2 \frac{m g}{L}\right)}-1\right]=3.725$

$k=0.0372 \mathrm{mg} / \mathrm{L}$ 


\section{Appendix B: Biosorbent regeneration studies}

\section{B-1. Effect of desorbing agent flow rate and concentration on biomass regeneration}

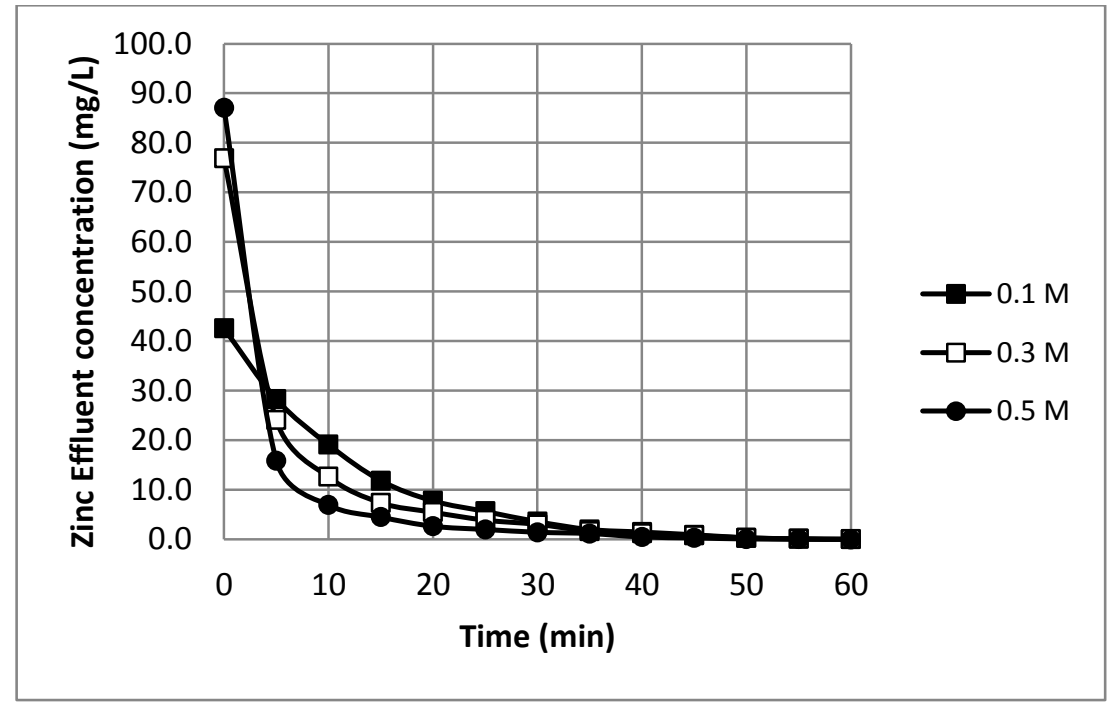

Figure B-1: Effect of hydrochloric acid concentration on desorption of $\mathrm{Zn}^{2+}$ at flow rate of $0.1 \mathrm{~L} / \mathrm{min}$

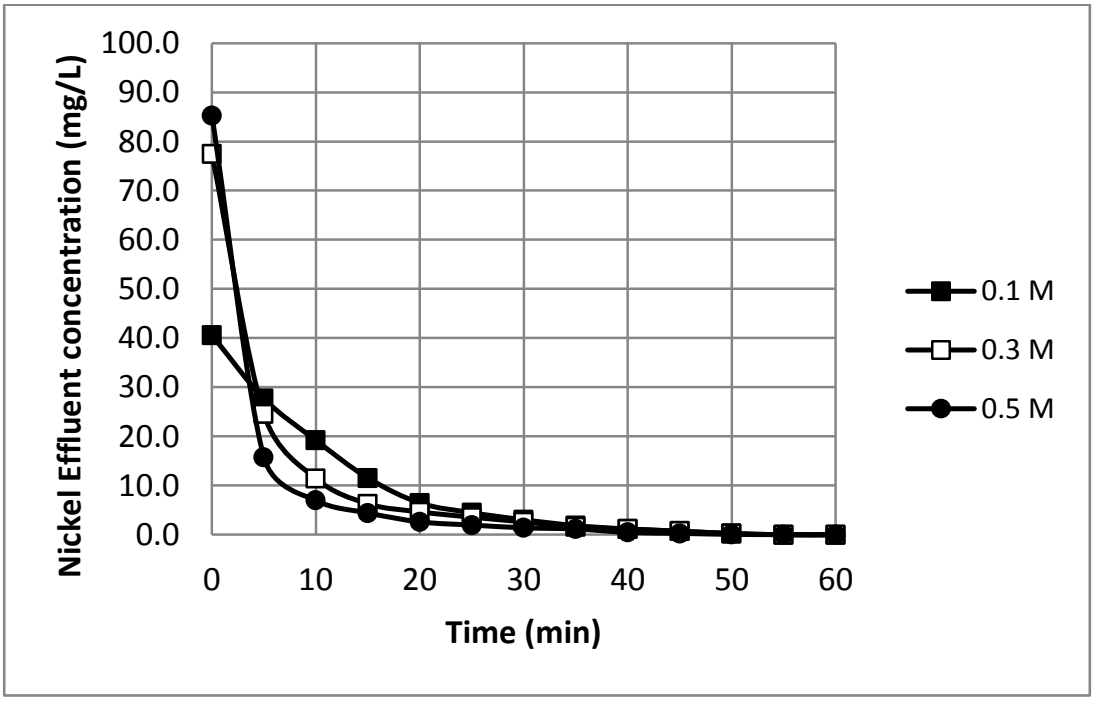

Figure B-2: Effect of hydrochloric acid concentration on desorption of $\mathrm{Ni}^{2+}$ at flow rate of $0.1 \mathrm{~L} / \mathrm{min}$ 


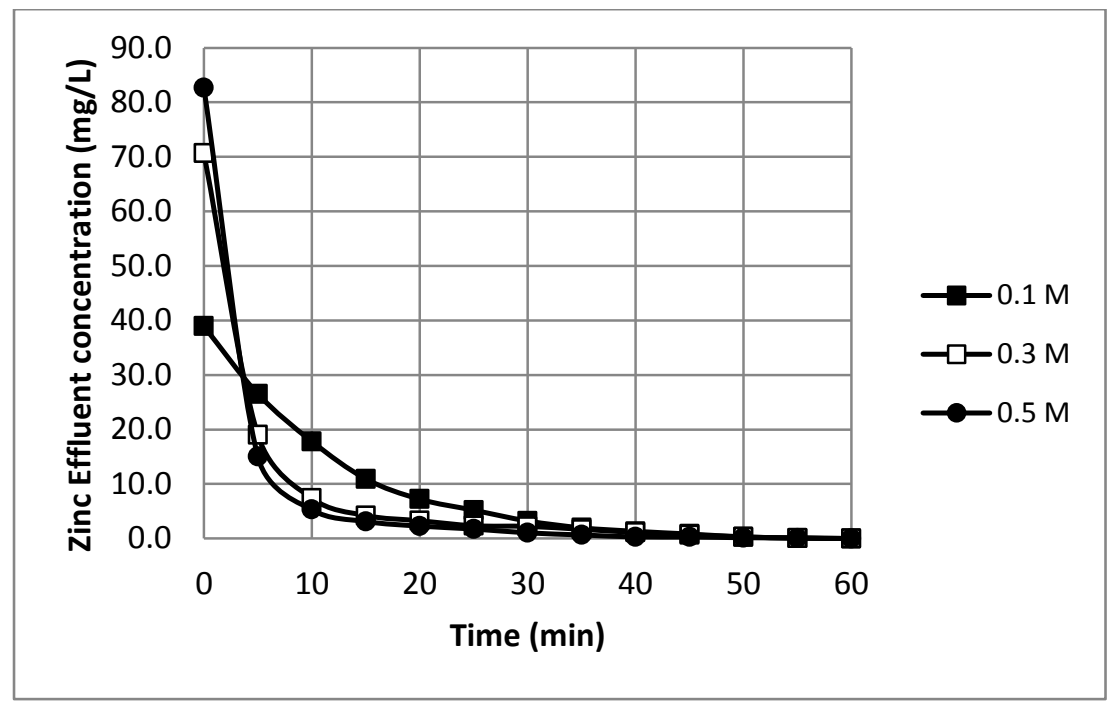

Figure B-3: Effect of nitric acid concentration on desorption of $\mathrm{Zn}^{2+}$ at flow rate of $0.1 \mathrm{~L} / \mathrm{min}$

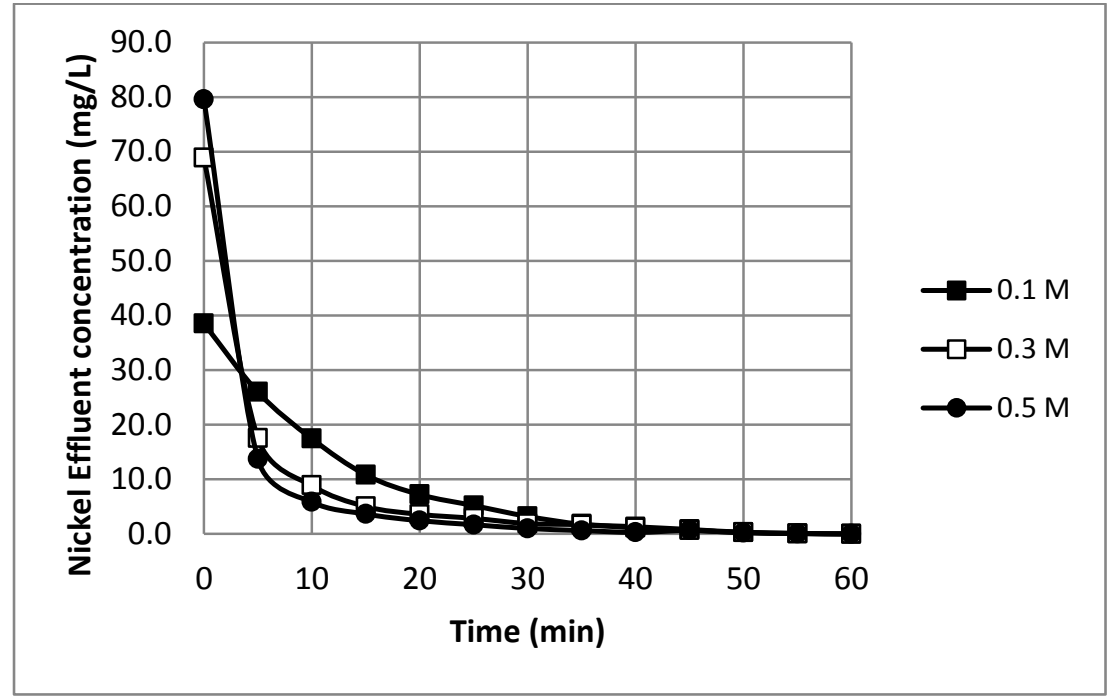

Figure B-4: Effect of nitric acid concentration on desorption of $\mathrm{Ni}^{2+}$ at flow rate of $0.1 \mathrm{~L} / \mathrm{min}$ 


\section{Appendix C: Electro-deposition studies}

Table C-1: Standard reduction potentials in aqueous media at $\mathbf{2 5}^{\circ} \mathbf{C}$ (Bret and Bret, 1993)

\begin{tabular}{|c|c|}
\hline Cathode (reduction) & Half-reduction Standard Potential $\mathbf{E}^{\mathbf{0}}(\mathrm{V})$ \\
\hline$L i^{+}(a q)+e^{-} \rightarrow \operatorname{Li}(s)$ & -3.04 \\
\hline$R b^{+}(a q)+e^{-} \rightarrow R b(s)$ & -2.98 \\
\hline$K^{+}(a q)+e^{-} \rightarrow K(s)$ & -2.93 \\
\hline$C s^{+}(a q)+e^{-} \rightarrow C s(s)$ & -2.92 \\
\hline$B a^{2+}(a q)+2 e^{-} \rightarrow B a(s)$ & -2.91 \\
\hline$S r^{2+}(a q)+2 e^{-} \rightarrow \operatorname{Sr}(s)$ & -2.89 \\
\hline $\mathrm{Ca}^{2+}(a q)+2 e^{-} \rightarrow \mathrm{Ca}(s)$ & -2.76 \\
\hline$N a^{+}(a q)+e^{-} \rightarrow N a(s)$ & -2.71 \\
\hline$M g^{2+}(a q)+2 e^{-} \rightarrow M g(s)$ & -2.38 \\
\hline$A l^{3+}(a q)+3 e^{-} \rightarrow A l(s)$ & -1.66 \\
\hline$M n^{2+}(a q)+2 e^{-} \rightarrow M n(s)$ & -1.19 \\
\hline$Z n^{2+}(a q)+2 e^{-} \rightarrow Z n(s)$ & -0.76 \\
\hline $\operatorname{Cr}^{3+}(a q)+3 e^{-} \rightarrow \operatorname{Cr}(s)$ & -0.74 \\
\hline$F e^{2+}(a q)+2 e^{-} \rightarrow F e(s)$ & -0.41 \\
\hline$C d^{2+}(a q)+2 e^{-} \rightarrow C d(s)$ & -0.40 \\
\hline $\mathrm{Co}^{2+}(a q)+2 e^{-} \rightarrow \operatorname{Co}(s)$ & -0.28 \\
\hline$N i^{2+}(a q)+2 e^{-} \rightarrow N i(s)$ & -0.23 \\
\hline$F e^{3+}(a q)+3 e^{-} \rightarrow F e(s)$ & -0.04 \\
\hline $2 H^{+}(a q)+2 e^{-} \rightarrow H_{2}(g)$ & 0.00 \\
\hline $\mathrm{Cu}^{2+}(a q)+e^{-} \rightarrow C u^{+}(a q)$ & 0.16 \\
\hline $\mathrm{Cu}^{2+}(a q)+2 e^{-} \rightarrow \mathrm{Cu}$ & 0.34 \\
\hline $\mathrm{O}_{2}+4 \mathrm{H}^{+}+4 e^{-} \rightarrow 2 \mathrm{H}_{2} \mathrm{O}$ & 1.23 \\
\hline
\end{tabular}




\section{C-2: Average mass transfer coefficient}

\section{Sample calculation}

According to Figure 25, at volumetric flow rate of 9.88 LPM and current density of $3.75 \mathrm{~mA} / \mathrm{cm}^{2}$ , the equation representing $\operatorname{Ln}\left(\mathrm{C} / \mathrm{C}_{\mathrm{o}}\right)$ vs. time for $\mathrm{Zn}^{2+}$ binary deposition can be written as;

$y=-0.0008 x+0.0221$

Where, Apparent rate constant, $\mathrm{k}=0.0008\left(\mathrm{~min}^{-1}\right)$

The average mass transfer coefficient, $k_{\mathrm{c}}$ can be obtained as below:

$$
k_{c}=k \frac{V}{A}
$$

Where, $\mathrm{V}($ volume of the electrolyte $)=7$ Liter, $\mathrm{A}($ Cathode surface area $)=360 \mathrm{~cm}^{2}$

$k_{c}=\frac{0.0008 * 7 * 1000}{360}=0.0155$ or $1.55 * 10^{-2} \mathrm{~cm} / \mathrm{min}$

\section{Calculation the dimensionless mass transfer coefficient $\left(\mathbf{J}_{\mathrm{D}}\right)$}

The $J_{\mathrm{D}}$ factor is defined as:

$$
J_{D}=\frac{S h}{R e \cdot S c^{1 / 3}}
$$

\section{Calculation Reynolds number}

Reynolds number: $R e=\frac{D . \rho . u}{\mu}$

$\mathrm{D}$ is hydraulic diameter of the electro-deposition cell, which can be calculated from following equation;

$D=\frac{4 \cdot x \cdot y}{2(x+y)}$

Where, $\mathrm{x}=0.055 \mathrm{~m}$ and $\mathrm{y}=0.2 \mathrm{~m}$ as the height and width of the reactor

$D=\frac{4 * 0.05 * 0.2}{2(0.05+0.2)}=0.08$

By using data available in Table 23, Reynolds number can be calculated easily at given flow rate of $0.0165 \mathrm{~m}^{3} \cdot \mathrm{m}^{-2} \cdot \mathrm{s}^{-1}$ : 
$\operatorname{Re}=\frac{\left(946 \frac{\mathrm{kg}}{\mathrm{m}^{3}}\right) *\left(\frac{0.0165 \mathrm{~m}^{3}}{\mathrm{~m}^{2} * \mathrm{~s}}\right) *(0.08 \mathrm{~m})}{0.000964 \frac{\mathrm{kg}}{\mathrm{m} . \mathrm{s}}}$

$R e=1295$

\section{Calculation of Schmidt number:}

Schmidt number: $S c=\frac{\mu}{\rho \cdot D_{A B}}$

$S c=\frac{\left(0.000964 \frac{\mathrm{kg}}{\mathrm{m} \cdot \mathrm{S}}\right)}{\left(946 \frac{\mathrm{kg}}{\mathrm{m}^{3}}\right) *\left(7.02 * 10^{-10} \frac{\mathrm{m}^{2}}{\mathrm{~s}}\right)}$

$\mathrm{Sc}=1451.61$

\section{Calculation of Sherwood number}

$\mathrm{L}$ is the hydraulic diameter of the opened-channel electro-cell $=0.086 \mathrm{~m}$

Sherwood number: $S h=\frac{k_{c} \cdot L}{D_{A B}}$

$S h=\frac{\left(1.55 * \frac{10^{-2} \mathrm{~cm}}{\min }\right) * 0.086 * 1 \mathrm{~min} * 1 \mathrm{~m}}{\left(7.02 * 10^{-10} \frac{\mathrm{m}^{2}}{\mathrm{~s}}\right) * 60 \mathrm{~s} * 100 \mathrm{~cm}}$

$S h=317.50$

Thus, mass transfer coefficient $\left(\mathrm{J}_{\mathrm{D}}\right)$ can be calculated as:

$$
\begin{aligned}
& J_{D}=\frac{S h}{R e \cdot S c^{1 / 3}} \\
& J_{D}=\frac{(317.50)}{(1295) \cdot(1451.61)^{1 / 3}} \\
& \mathrm{~J}_{D}=0.022
\end{aligned}
$$




\section{Appendix D: Economic evaluation}

All cost for the recovery of $\mathrm{Zn}^{2+}$ and $\mathrm{Ni}^{2+}$ binary from wastewater using integrated biosorption and electro-deposition under best operational conditions for biosorption, desorption and electrodeposition processes are presented in Table D-1.

Table D-1: Summary of operational cost per liter wastewater under the best experimental operational conditions

\begin{tabular}{|c|c|c|c|}
\hline & Biosorption & Desorption & Electro-deposition \\
\hline $\begin{array}{c}\text { Wheat straw cost per } \\
\text { liter wastewater } \\
\text { (\$/liter) }^{[1]}\end{array}$ & $9.2 \times 10^{-4}$ & --- & -- \\
\hline $\begin{array}{c}\text { Chemical costs per } \\
\text { liter wastewater } \\
\text { (\$/liter) }^{[2][3]}\end{array}$ & $3.5 \times 10^{-3}$ & $4.4 \times 10^{-3}$ & $8.5 \times 10^{-3}$ \\
\hline $\begin{array}{c}\text { Energy costs per liter } \\
\text { wastewater } \text { (\$/Liter) }\end{array}$ & $9.67 \times 10^{-8}$ & $9.65 \times 10^{-8}$ & $8.03 \times 10^{-6}$ \\
\hline $\begin{array}{c}\text { Total operation cost } \\
\text { per liter wastewater } \\
\text { (\$/Liter) }\end{array}$ & $4.4 \times 10^{-3}$ & $4.4 \times 10^{-3}$ & \\
\hline $\begin{array}{c}\text { Net operation cost per } \\
\text { liter wastewater } \\
\text { (\$/Liter) }\end{array}$ & & $1.73 \times 10^{-2}$ & \\
\hline
\end{tabular}

[1] The cost of wheat straw is \$ 24 per ton biomass (Alberta Agriculture and Rural Development, 2009).

${ }^{[2]}$ The list of chemicals used in this study includes, sulphuric acid, zinc sulphate, nickel sulphate, potassium chloride, potassium hydroxide, and so on.

[3] The chemicals were purchase from VWR for the chemicals in reasonable price (VWR a-e, 2013).

The pump power and electrical cost calculated is based on the following equation (Girdhar, 2008):

$$
p=\frac{Q \times H \times g \times \rho}{\eta}
$$

Where, $P$ the power $(\mathrm{W}), \rho$ is density $\left(\mathrm{Kg} / \mathrm{m}^{3}\right), \mathrm{Q}$ is the flow rate $\left(\mathrm{m}^{3} / \mathrm{s}\right), \mathrm{H}$ is the total dynamic head (m-water), $\mathrm{g}$ is the gravitational constant $\left(9.81 \mathrm{~m} / \mathrm{s}^{2}\right)$ and $\eta$ is the pump efficiency. 


\section{Sample calculation for biosorption process:}

Total dynamic head calculation (Orion Fittings, 2013):

The difference between pumping level and feed tank: $0.25 \mathrm{~m}$ or 9.84 inch

Friction head loss based on $90^{\circ}$ elbows and pipes:

$1 / 2$ inch $90^{\circ}$ standard elbow $=1.6 \times 3$ elbow $=4.8$ inch $=0.12 \mathrm{~m}$

$1 \mathrm{~m}$ of 1/2 inch plastic pip: (2.08' friction loss $/ 39.37$ inch pipe $) \times 9.84 \mathrm{in}=0.41 \mathrm{inch}=0.01 \mathrm{~m}$

Total head loss $=0.25+0.12+0.01=0.38 \mathrm{~m}$-water

\section{Calculation the pump power and electrical cost:}

- Flow rate $=0.1 \mathrm{~L} / \mathrm{min}=1.67 \times 10^{-6} \mathrm{~m}^{3} / \mathrm{s}$

- $\rho=1000 \mathrm{~kg} / \mathrm{m}^{3}$

- $\mathrm{H}$ (total dynamic head $)=0.38 \mathrm{~m}$-water

- $\quad$ Pump efficiency $=95 \%$ (The efficiency of diaphragm pump ranges from $94-97 \%$, so an efficiency of $95 \%$ will be assumed (Girdhar, 2008)).

- $\mathrm{g}=9.81 \mathrm{~m} / \mathrm{s}^{2}$

$$
p=\frac{1.67 \times 10^{-6} \times 0.38 \times 9.81 \times 1000}{0.95}=6.54 \times 10^{-3}(\mathrm{~W})=6.54 \times 10^{-6}(\mathrm{~kW})
$$

The price electricity rate in Toronto is $8.7 \notin / \mathrm{kwh}$ (Toronto Hydro, 2012), and the time required to pump 1 liter at the given flow rate is 0.17 hour. Electrical cost is calculated by multiply this time by the calculated power which yield the amount of energy required to pump that specific amount of fluid. This energy figure is then multiplied by the cost per energy value input by the user.

The electrical cost is calculated as $\$ 9.67 \times 10^{-8}$ per litre wastewater. 